\title{
TITLE:
}

\section{THE ZOOGEOGRAPHICAL ASPECTS OF THE JAPAN SEA -PART V-}

AUTHOR(S):

Nishimura, Saburo

CITATION:

Nishimura, Saburo. THE ZOOGEOGRAPHICAL ASPECTS OF THE JAPAN SEA -PART V-. PUBLICATIONS OF THE SETO MARINE BIOLOGICAL LABORATORY 1969, 17(2): 67-142

\section{ISSUE DATE:}

1969-09-30

URL:

http://hdl.handle.net/2433/175589

RIGHT: 


\title{
THE ZOOGEOGRAPHICAL ASPECTS OF THE JAPAN SEA \\ PART $V^{1)}$
}

\author{
SABURO NISHIMURA \\ Seto Marine Biological Laboratory, Sirahama
}

With Text-figures $31-48$

\section{CONTENTS}

4. Distribution of Animal Populations in Relation to the Hydrography of the Japan

Sea

4.1. The Oceanographic Structure and Animal Communities

4.2. Movement and Transformation of Water Masses and the Migrations of

Animal Populations

4.2.1. Winter to Spring Aspects .

4.2.2. Summer Aspects

4.2.3. Autumnal Aspects .......................................................... 99

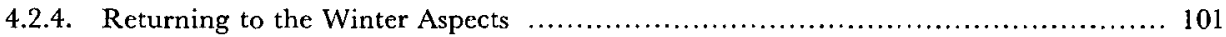

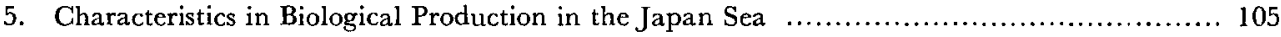

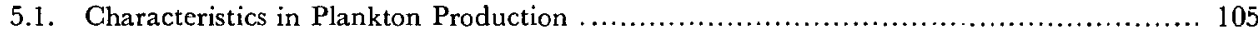

5.2. Biological Seasons and Bioclimatic Regions .......................................... 110

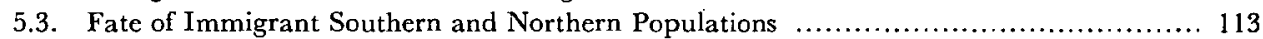

6. The Japan Sea as the Natural Environment of Animal Populations ........................... 120

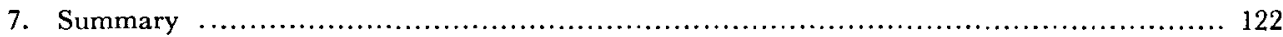

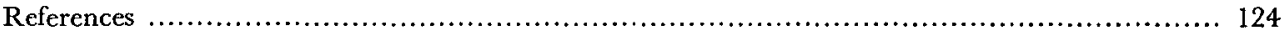

\section{Distribution of Animal Populations in Relation to the Hydrography of the Japan Sea}

In the preceding chapter, several promincnt fiatures of animal distribution in the Japan Sea were enumerated. Though they ware discussed in that chapter rather topically and separately from one another, most of them must be naturally closely related to one another or they might only represent diffirent aspects of the same phenomena. In this chapter, the $n$, some $\epsilon$ fforts will be made to integrate them in close reference to the dynamic processes taking place in the hydrographic and meteorological environments and to find out any physical mechanisms principally controlling the distributional phenom. na of animal populations in the Japan Sea.

1) Conributions from the Seto Marine Biological Laboratory, No. 508.

Publ. Seto Mar. Biol. Lab., XVII (2), 67-142, 1969. (Article 4) 


\subsection{The Oceanographic Structure and Animal Communities}

Since the middle of the 18th century, numerous hydrographic observations have been made in the Japan Sea; and today this marginal sea may safely be accepted as one of the seas surveyed most comprehensively on the earth. Based on the data thus accumulated, not a few authors have so far presented their opinions on the oceanographic structure of this sea, i.e., in other words, the discrimination of water masses and their relative situations within the basin of the Japan Sea. Among such authors are reckoned Suda (1929), Suda et al. (1930-33), Uda (1934a, 1934b, 1936), Leonov (1948), Mryazaki (1953), Akagawa (1954), Miyazaki \& Abe (1960), RadzIKHOVSKAYA (1961), etc. Their conclusions agree generally with one another on broad lines, but differ significantly in several important points. Such differences
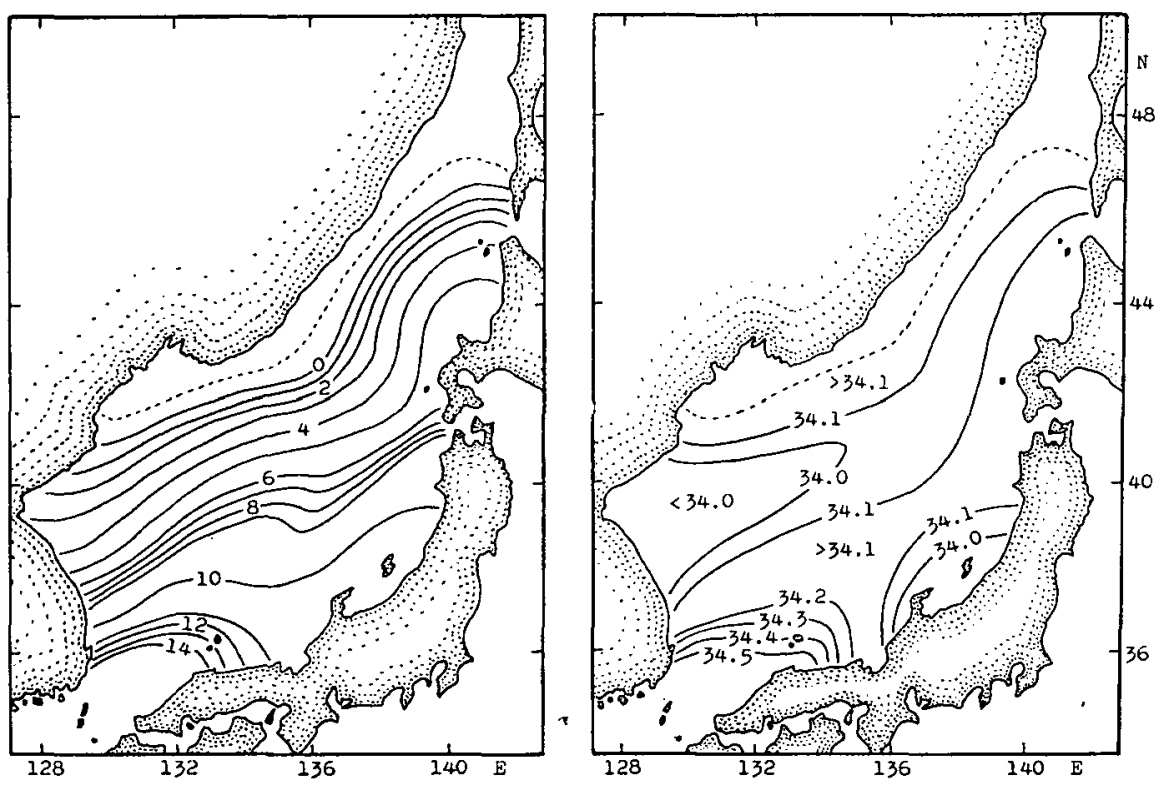

Fig. 31. Average surface temperature (left, in ${ }^{\circ} \mathrm{C}$ ) and salinity (right, in $\%$ ) in winter. The broken line in the northern region indicates the southern limit of sea ice.

are due principally to the regional or seasonal limitation of the data available to those authors. Making reference to all of these previous conclusions and further consulting with the original data, a proposal of distinguishing between the water masses of the Japan Sea is here made in a somewhat simplified manner, but to see the dynamic structure of the shallow layer in particular detail in a hope to clear the physical factors affecting the distributions of the shallow-water animal populations best studied in this marginal sea (cf. Chapter 3).

In the discussion to follow, the winter and summer conditions will be mentioned separately, as the hydrographic condition in the Japan Sea differs so much between 
the two seasons; the spring and autumnal conditions, on the other hand, are not only intermediate or transitional between those two extreme conditions but also they are maintained respectively for a shorter time.

As readily seen in Figs. 31 and 32 which illustrate schematically the winter hydrographic condition of the Japan Sea, the main region of this sea in the winter season can be considered on the first approximation consisting of two major layers of distinct
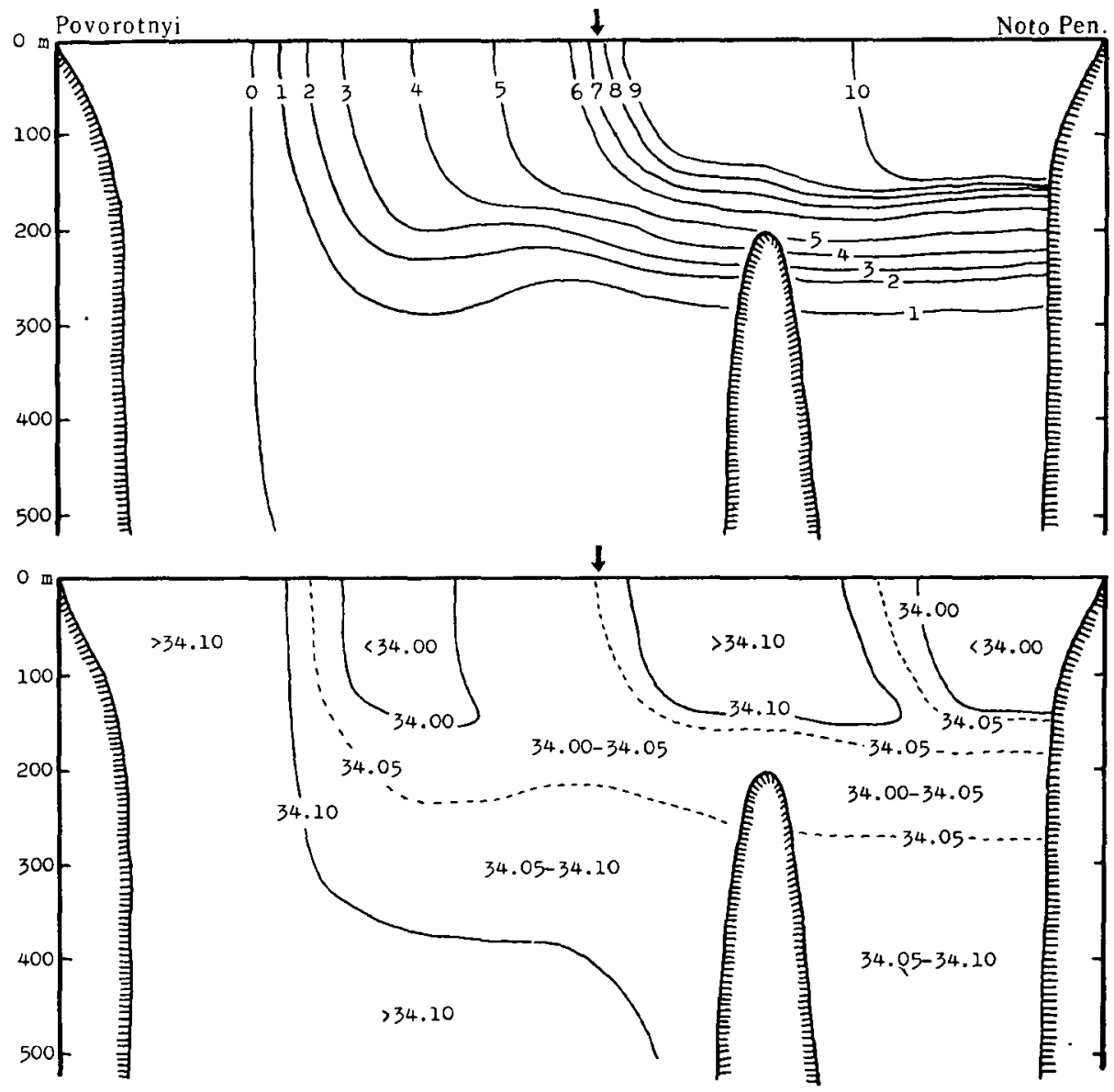

Fig. 32. Average vertical distributions of temperature (above, in ${ }^{\circ} \mathrm{C}$ ) and salinity (below, in \%o) in the upper $500 \mathrm{~m}$ of a section through Noto Peninsula, middle Honshu, and Cape Povorotnyi, southern Maritime Province, in winter. Thick arrows indicate the approximate position of the Polar Front.

water systems, i.e., the upper and lower layers. The upper layer water is confined to the shallower levels of the region south of the subarctic convergence or the Polar Front that runs across the present marginal sea from off the southeast coast of Korean Peninsula to the west entrance of the Tsugaru Straits, and its temperature and salinity 
changes, though considerable in range, are rather gradual within its domain. This water is to be called the Upper Water for the time being. The lower layer water, on the other hand, is not only underlying the Upper Water in the southern region but also found throughout the strata from the surface to bottom in the region north of the Polar Front; and it may be subdivided into two parts according to the geographical and hydrological differentiation: one is the water mass occupying the shallow levels of the zone just adjacent to the north of the Polar Front but penetrating into the layer just below the Upper Water south of the Front and characterized by a significant range of temperature variation, and the other water mass, characterized by almost homogeneous temperature and salinity, is extending in the northwestern- and northernmost regions of the sea throughout the whole strata from the surface to bottom but toward the southeast being progressively confined to the deeper levels. Provisionally, the former is called here the Southern Lower Water and the latter the Northern Lower Water. According to the views of some previous authors, the Northern Lower Water seems further to be divided into two subtypes, i.e., the Deep Water and the Bottom Water.

The above-mentioned classification of the winter water systems in the Japan Sea and the hydrographic characteristics and spatial distribution of respective water masses thus discriminated are summarized as follows (abbreviations for text-figures are shown in parentheses):

1. UPPER WATER SYSTEM

1a. Upper Water $(\mathrm{Tw}) \ldots 7-13^{\circ} \mathrm{C}, 34.05-34.35 \%$ o $\mathrm{S}$; surface to ca. 150 $200 \mathrm{~m}$ in the southeastern rcgion excluding the area off the western part of San'in District of west Honshu (for the situation in the latter area, see below, pp. 74-75).

2. LOWER WATER SYSTEM

2a. Southern Lower Water $(\mathrm{Li}) \ldots 1-7^{\circ} \mathrm{C}, 34.00-34.05 \%$ S; ca. 200 to ca. $250 \mathrm{~m}$ in the southeastern region, surface to ca. $200 \mathrm{~m}$ in the central region.

2b. Northern Lower Water $(\mathrm{Ln}) \ldots<1^{\circ} \mathrm{C},>34.05 \% \mathrm{~S}$; ca. $300 \mathrm{~m}$ to bottom in the southeastern and central regions, surface to bottom in the northwestern and northern regions; two subtypes discernible:

$$
\left\{\begin{array}{l}
\text { Deep Water (D) } \ldots .0 .3-1^{\circ} \mathrm{C}, 34.05-34.10 \% 0 \mathrm{~S} \\
\text { Bottom Water (B) }
\end{array}\right.
$$

As to the summer condition, the hydrographic fuatures of which are schematically shown in Figs. 33 and 34, the following three major water systcms are rucognizable: the Superficial Water ${ }^{2)}$, the Upper Water and the Lower Water. The Superficial Water,

2) The term Surface Water is avoided here, because firstly some authors (e.g., RADzikHovskaya 1961) have ever defined this term to comprize the Upper Water of my definition as well as the Superficial Water together, and secondly the superficial water of the surface layer of the Japan Sea differs significantly from the surface layer water of the open ocean, which is usually rather homogeneous up to the very surface, in that it is greatly diluted by the drainage from land (see below, pp. 93-94). 

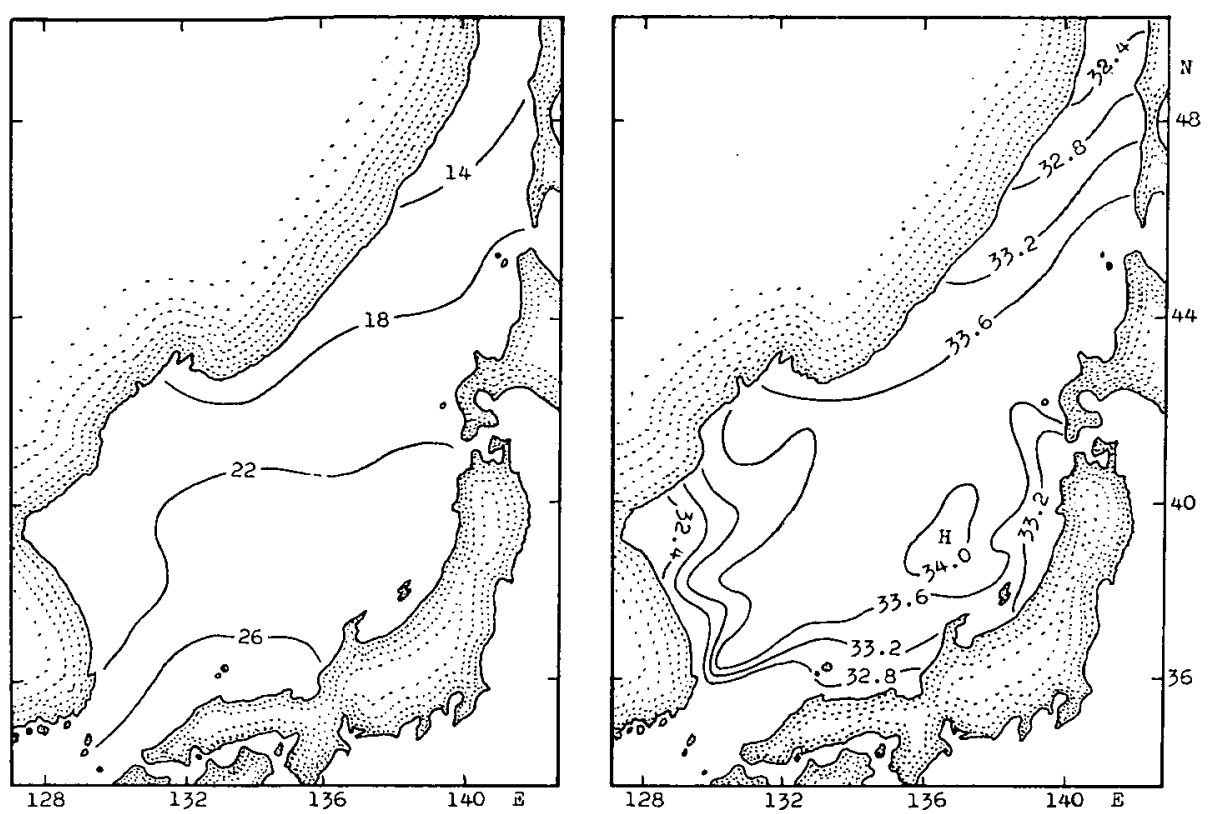

Fig. 33a. Average surface temperature (left, in ${ }^{\circ} \mathrm{C}$ ) and salinity (right, in $\%$ ) in summer.
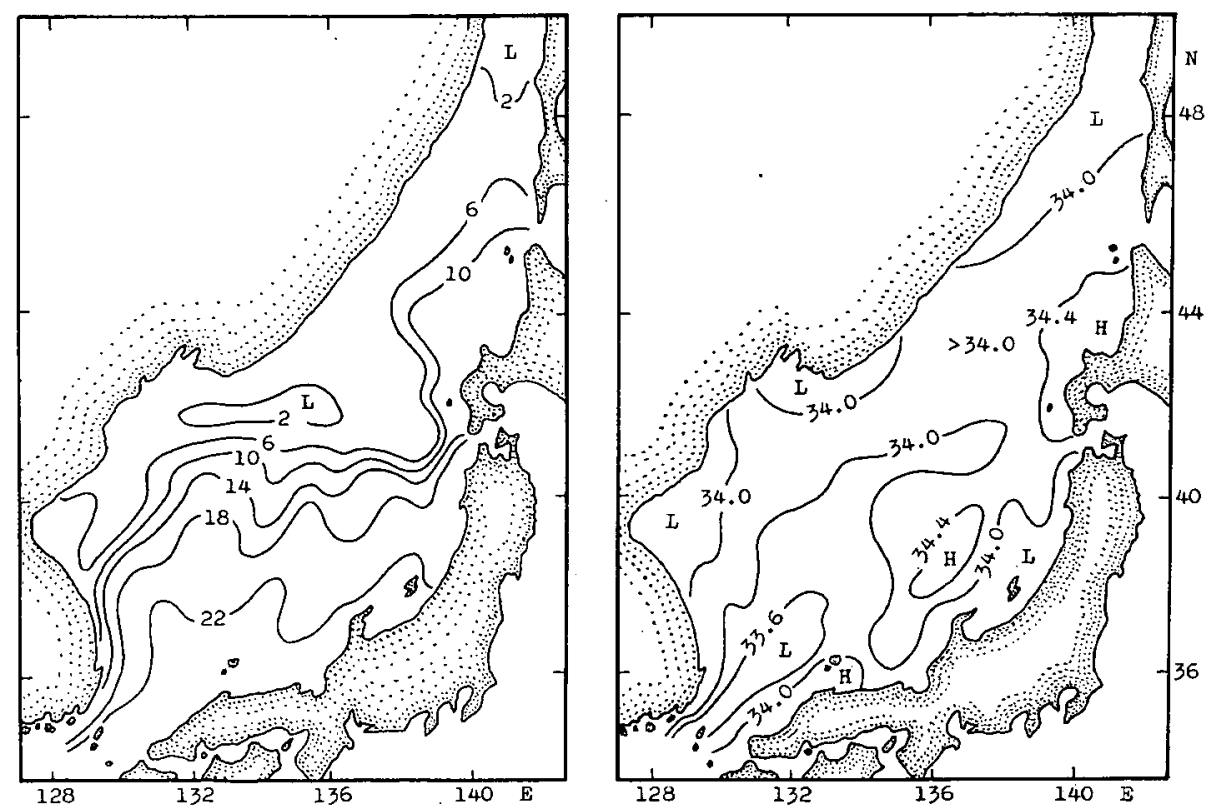

Fig. 33b. Average temperature (left, in ${ }^{\circ} \mathrm{C}$ ) and salinity (right, in $\%$ ) at the $50 \mathrm{~m}$ layer in summer. 
quite distinct from the last two, is remarkably developed in the summer season to cover the whole Japan Sea. After the opinions of many previous authors, this water is divided into the Southeast Superficial Water (or the Superficial Water of the Warm Tsushima Current Region) and the Northwest Superficial Water (or the Superficial Water of the Cold Liman Current Region), though the distinction is not always very clear. Due to the extension of this relatively homogeneous Superficial Water nearly over the whole area

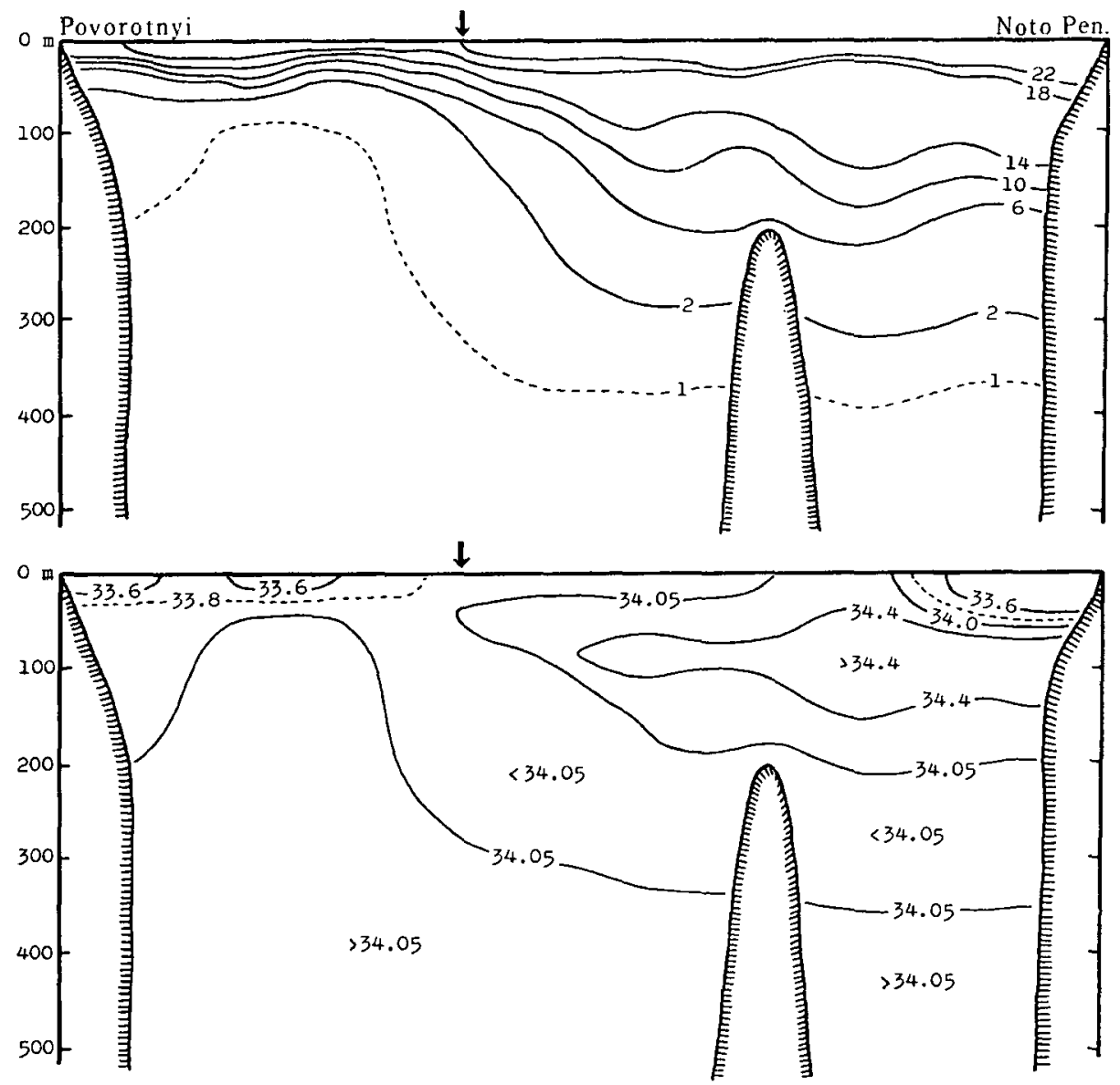

Fig. 34. Average vertical distributions of temperature (above, in ${ }^{\circ} \mathrm{C}$ ) and salinity (below, in $\%$ ) in the upper $500 \mathrm{~m}$ of a section through Noto Peninsula, middle Honshu, and Cape Povorotnyi, southern Maritime Province, in summer. Thick arrows indicate the approximate position of the Polar Front.

of the sea, the distribution of surface water temperature and salinity assumes each a rather flat pattern in the main region of the sea (Fig. 33a), though the Polar Front is retained markedly at the $50 \mathrm{~m}$ layer (Fig. $33 \mathrm{~b}$ ) and distinctly separating the southeastern and northwestern regions as in the winter season. The summer Upper Water, 
which is generally confined to the shallower levels in the region south of the Polar Front as is the winter Upper Water, is composed of two distinct parts: one is the so-called Core Water of the Warm Tsushima Current derived from the NW Pacific Central Water and the other is the Japan Sea Central Water (Mryazaki \& Abe 1960), the latter seemingly corresponding in its essence to the core water of the Upper Water of the winter season which has persisted till summer. Lastly, the Lower Water of the summer season which underlies the Upper Water consists of three parts: the first is the so-called Intermediate Water probably corresponding to the core water or slightly modified one of the Southern Lower Water of the winter season which has persisted till summer and penetrating down to immediately below the Upper Water in the southeast region from below the Superficial Water in the northwest region, the second is the Deep Water and the last the Bottom Water. The last two water masses are highly stable in temperature and salinity characteristics and persist in the deeper levels of the sea, without any significant seasonal variation.

Thus, the water systems and masses in the summer condition together with their hydrographic characteristics and spatial distribution are summarized as follows (abbreviations for text-figures in parentheses):

1. Superficial Water system

la. Southeast Superficial Water (Ts) $\ldots .21-28^{\circ} \mathrm{C}, 33.0-34.1 \% 0 \mathrm{~S}$; surface to ca. 50-100 $\mathrm{m}$ deep in the south and inshore, but less in the north and offshore.

1b. Northwest Superficial Water (Ls) ... 13-21 ${ }^{\circ} \mathrm{C}, 32.0-33.5 \%$ S; surface to ca. $10-30 \mathrm{~m}$.

2. UPPER WATER SYSTEM

2a. Tsushima Gurrent Core Water $(\mathrm{Tm}) \ldots 14-17^{\circ} \mathrm{C}, 34.4-34.7 \%$ S ; ca. 50-100 to ca. 120-150 m, generally thicker and deeper in the south, but thinner and shallower in the north.

2b. Japan Sea Central Water (Tc) ... 9-11 ${ }^{\circ} \mathrm{C}, 34.1-34.3 \%$ S; ca. 150 to ca. $200 \mathrm{~m}$, shallowing offshore.

3. LoWer WATER SYSTEM

3a. Intermediate Water (I) $\ldots, 3-4^{\circ} \mathrm{C}, 33.90-34.05 \% \mathrm{~S}$; ca. 200 to ca. $300 \mathrm{~m}$ in the southeastern region, ca. 50 to ca. $150 \mathrm{~m}$ in the northwestern region.

3b. $\left\{\begin{array}{l}\text { Deep Water (D) ... } 0.3-1^{\circ} \mathrm{C}, 34.05-34.10 \% 0 \mathrm{~S} ; \mathrm{ca} .400 \text { to ca. } 600-800 \mathrm{~m} \\ \text { in the southeastern region, ca. } 200 \text { to ca. } 400-500 \mathrm{~m} \text { in the north- } \\ \text { western region. } \\ \text { Bottom Water (B) ... } 0.1-0.2^{\circ} \mathrm{C}, 34.10-34.15 \% \mathrm{~S} ; \text { ca. } 500-1000 \mathrm{~m} \\ \text { to bottom throughout the sea. }\end{array}\right.$

In Fig. 35, ranges of these water masses are projected on the T-S diagram characterizing several representative areas of the Japan Sea. As noted easily, most of these water masses may generally be discernible by temperature difference alone, without 
reference to salinity at all. It is also noted on the winter T-S diagram (Fig. 35b) that, in addition to the three water masses mentioned previously (p. 70), there occurs another water mass slightly warmer and a little more haline than the normal Upper Water (Tw) on the continental shelf off the west part of San'in District of Honshu in the cold season; and actually a more or less distinct convergence is formed between it and the normal Upper Water mass there (cf. Fig. 31). That water mass is considered to represent a peripheral portion of the NW Pacific Central Water that ever flows into the Japan Sea in the winter season, the period of the minimum inflow of the warm current into the sea. This water mass may be included in the Upper
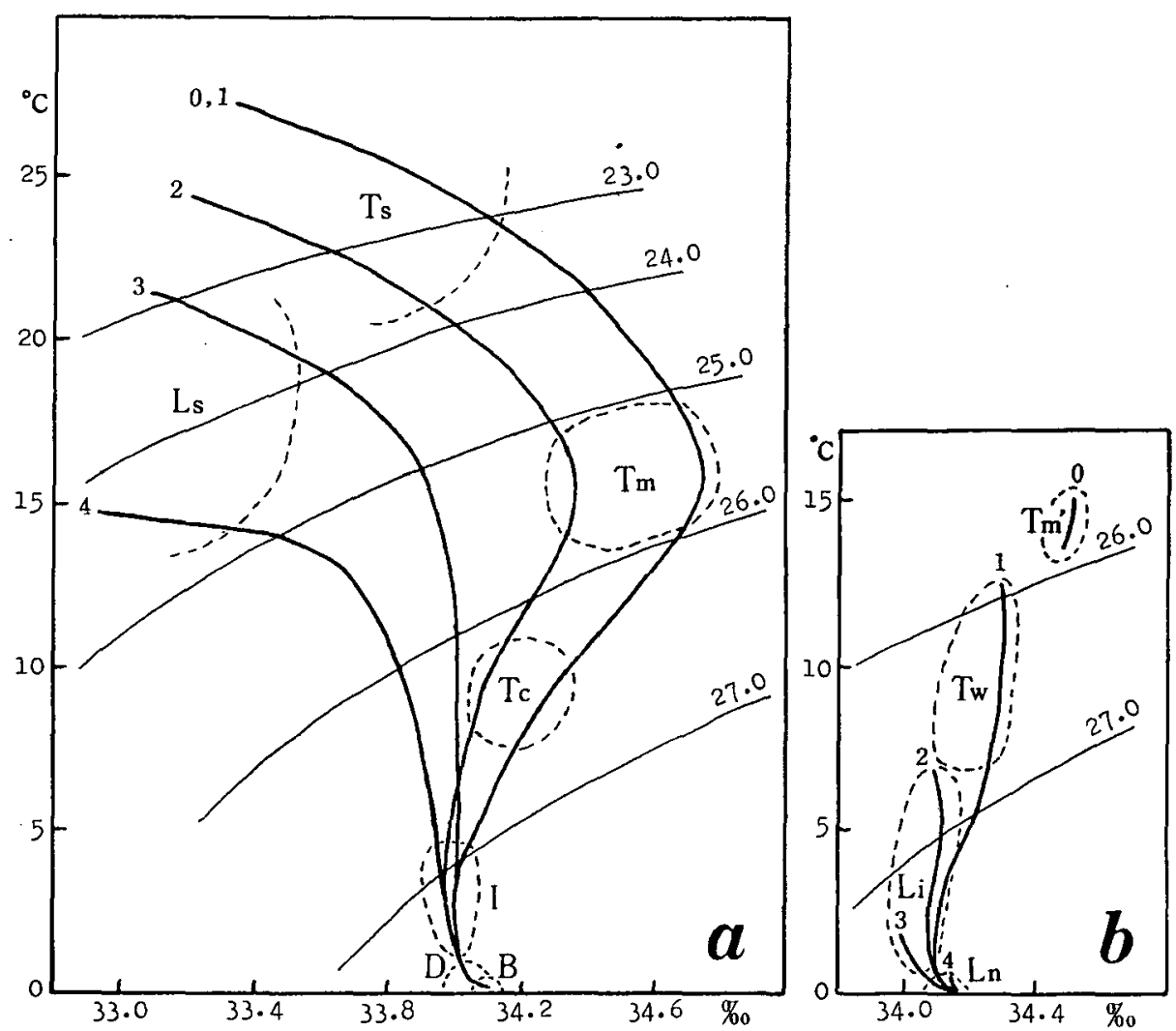

Fig. 35. T-S diagrams of different water masses in the Japan Sea in summer (a) and winter $(b)$ seasons, together with representative sigma- $t$ surfaces.

Thicker lines are the representative T-S curves respectively observed off the west part of San'in District (0), off the west coast of middle Honshu (1), off the west coast of northern Honshu (2), off the east coast of Korea (3), and off the Maritime coast (4).

Ts is the sign for the Southeast Superficial Water, Ls for the Northwest Superficial Water, Tm for the Tsushima Current Core Water, Tm' for the Peripheral Northwest Pacific Central Water, Tw for the Upper Water, Tc for the Japan Sea Central Water, $\mathrm{Li}$ for the Southern Lower Water, I for the Intermediate Water, Ln for the Northern Lower Water, D for the Deep Water, and B for the Bottom Water. 
Water system of the winter condition but must be treated separately from another component of the system under the name Peripheral NW Pacific Central Water (abbreviation in text-figures, $\mathrm{Tm}^{\prime}$; $13-15^{\circ} \mathrm{C}, 34.4-34.6 \% \mathrm{~S}$ ).

Summarizing the characteristics of respective water masses and their distribution mentioncd so far, Figs. $36 a, b$ are prepared to show schematically the oceanographic structures of the Japan Sea in the winter and summer seasons, respectively. The most important feature seen in these figures is that in both seasons, and resultantly in all probability throughout the year, the Polar Front is maintained very clearly in this marginal sea almost constantly. In winter, the Upper Water faces directly the atmosphere and the Polar Front is discernible very clearly on the sea surface. In summer, however, the Upper Water is sandwiched in between the Superficial Water and the Lower Water, thus, the Polar Front becomes obscure on the sea surface though invariably distinctive in subsurface layers.

Of those water masses mentioned above, the Northern Lower Water deserves a special attention, because it is distinctly colder, less haline and much more oxygenated than the corresponding Deep and Bottom Water masses of the Pacific. Evidently, the Northern Lower Water is formed within the Japan Sea (authigenic) and the permanent maintenance of its hydrographic distinctiveness is due to the complete isolation of the deep basin of the Japan Sea from the Pacific. As to the mechanism and place of formation of the Northern Lower Water, there is a famous supposition by SudA (1932) that this water of high density may be formed by midwinter cooling and salinity concentration due to freezing (hence, this is a primary water) in the northwestern region of the Japan Sea along the continent from the Tartary (Mamiya) Straits to Peter the Great Bay, sink down to the deeper levels, and follow slowly the large scale anti-clockwise flows along the isothermal (precisely, isentropic or the same density) planes deeper than $1000 \mathrm{~m}$. It is explicitly implied that on account of the addition of this cold haline water to the Bottom Water every winter an equal quantity of the latter must be removed to shallower levels to become through a mixing process the so-called Deep Water, a secondary water which will further be mixed with the overlying water masses and eventually be dissipated away. This process is schematically shown in Fig. 37 on p. 84 of this paper.

Detailed discussions on the mechanisms, places of formation and routes of dispersal of the other water masses are beyond the scope of this paper, but some points of them are outlined here in the following table.

WINTER WATER MASSES :

I. Authigenic primary water.........U. Upper Water; Southern Lower Water; Bottom Water.

II. Authigenic secondary water........ Deep Water.

III. Allothigenic primary water........ Peripheral NW Pacific Central Water.

SUMmer WATER MASSES:

I. Authigenic primary water......... Northwest Superficial Water (cf. p. 94); Bottom Water (persisting from winter).

II. Authigenic secondary water........Japan Sea Central Water (formed mainly through mixing within the winter Upper Water mass); Intermediate Water (formed through mixing within the winter Southern Lower Water mass and addition of cold and diluted water from thawing); Deep Water.

III. Allothigenic primary water.........Southeast Superficial Water.

IV. Allothigenic secondary water........ Tsushima Current Core Water (formed mainly through mixing within the NW Pacific Central Water mass). 


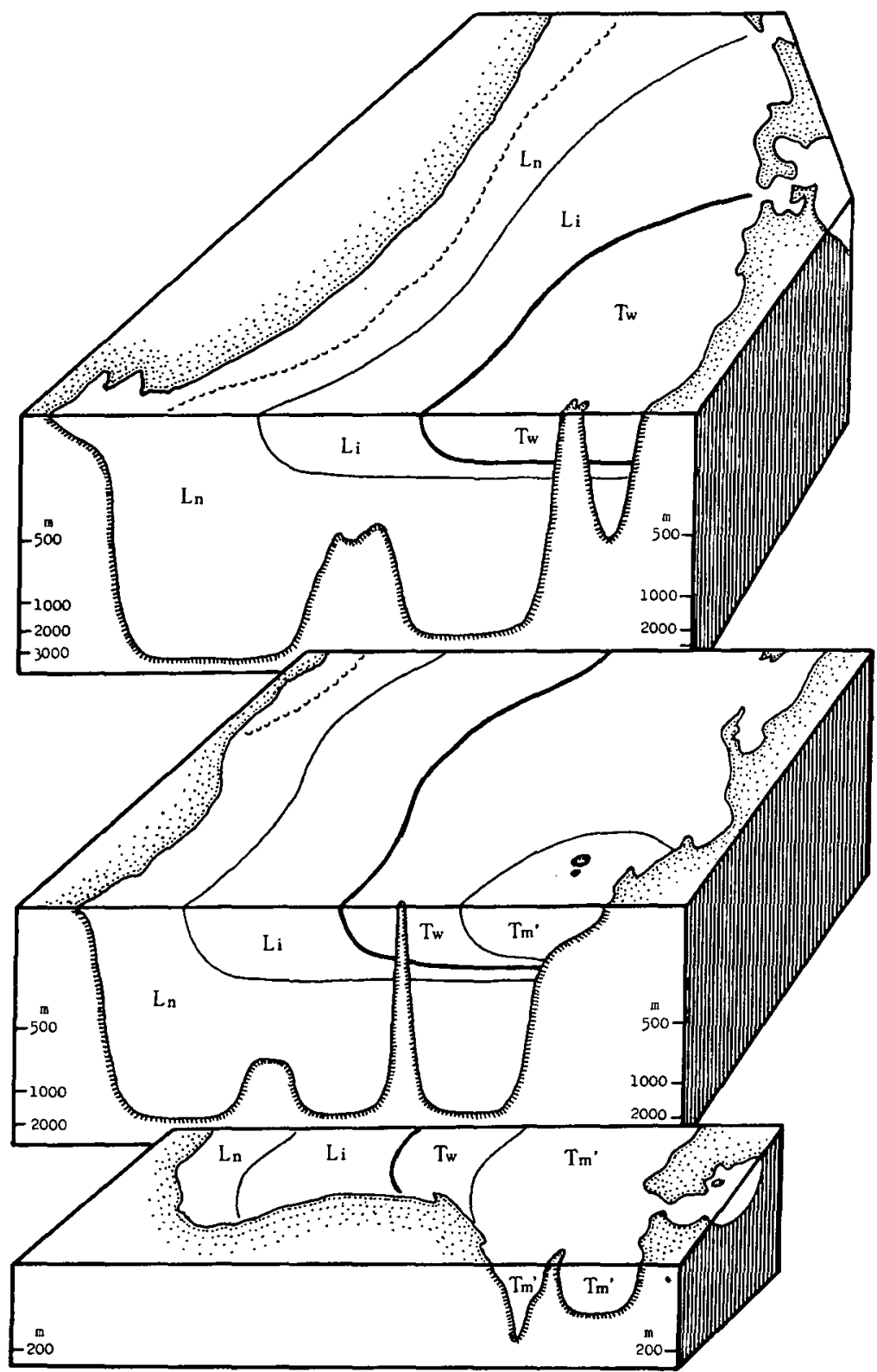

Fig. 36a. Block diagram showing the distributions of water masses in the Japan Sea in winter, with three sections respectively from Niigata in Hokuriku District, middle Honshu, to the southern part of Peter the Great Bay in southern Maritime Province (above), from near Hamada in San'in District, west Honshu, to Kimchek in northeast Korea (middle), and from northwest Kyushu to Pusan in southeast Korea through the Tsushima Straits (below).

For abbreviations for different water masses, see Fig. 35b. The boundary between the Upper Water system and the Lower Water system is shown by a thick line, of which the exposed portion corresponds to the Polar Front. The series of curved dashes on the surface in the northwestern region of the sea indicates the southern limit of sea ice. 


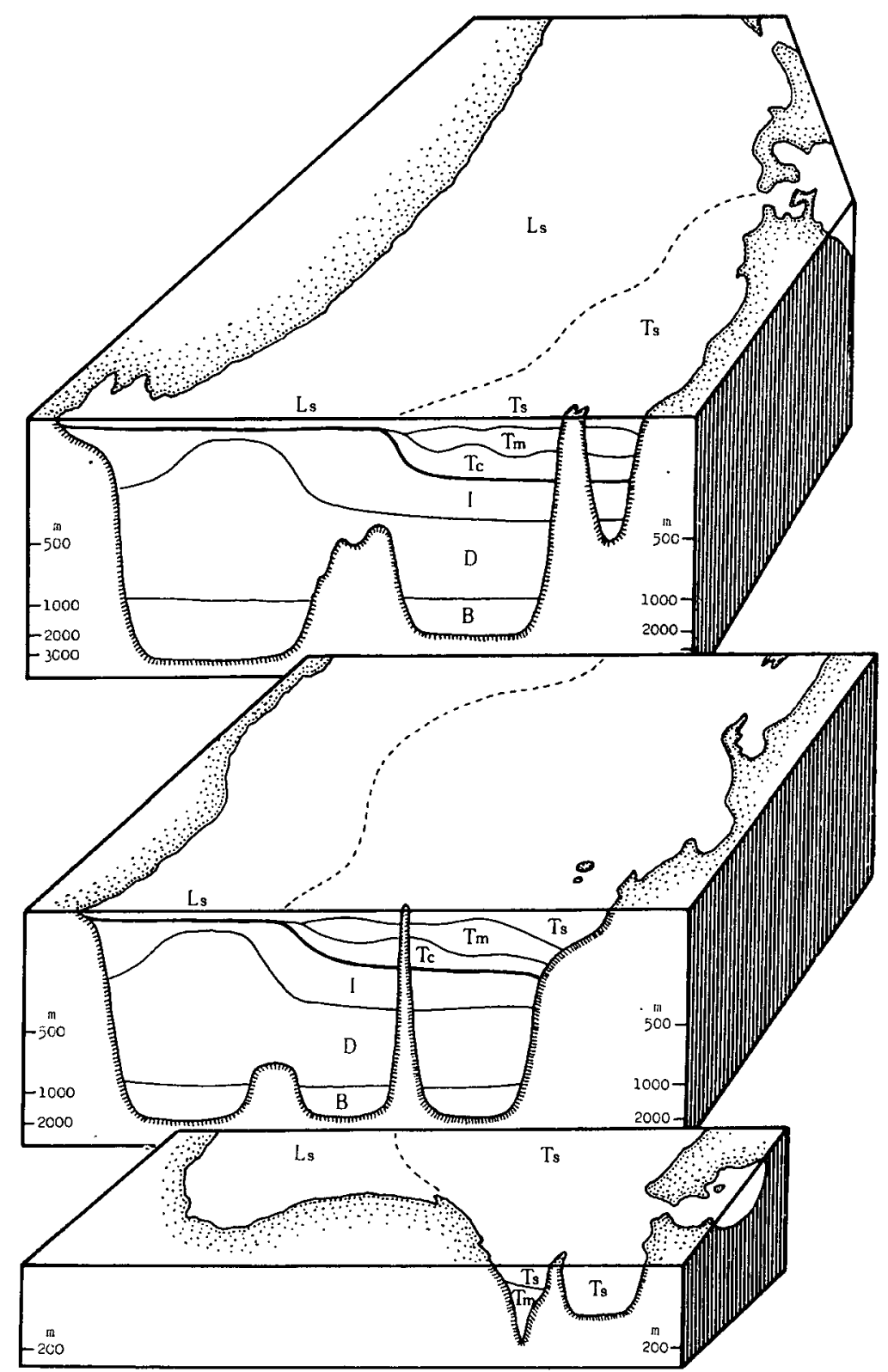

Fig. 36b. Block diagram showing the distributions of water masses in the Japan Sea in summer.

For abbreviations for different water masses, see Fig. 35a. The boundary between the Superficial-Upper Water system and the Lower Water system is shown by a thick line. The broken line on the surface indicates the position of the submerged Polar Front in summer. 
Now, comparing the oceanographic structure of the Japan Sea, especially that in the summer season, with the occurrence pattern of various animal communities in the same sea discussed at length previously (Sections 3.1, 3.3, 3.9, 3.10 and 3.11), the following important conclusions are gained.

A) There is an intimate correlation between the animal communities and the water masses (except, for the time being, for the okaba community III and the taraba community $I$, as no corresponding water masses are defined exactly).

B) Correlation of the following combinations is seen between respective animal communities and water masses:

\begin{tabular}{|c|c|c|c|}
\hline Pelagic communitie & Demersal communities & WATER MASSES & \multirow{2}{*}{$\begin{array}{l}\text { WATER SYSTEMS } \\
\text { Superficial } \\
\text { Water system }\end{array}$} \\
\hline $\begin{array}{l}\text { Surface tropical- } \\
\text { subtropical com- } \\
\text { munity }\end{array}$ & . Okaba community I & .. Superficial Water & \\
\hline \multirow{2}{*}{$\begin{array}{l}\text { Mid-water sub- } \\
\text { tropical to tem- } \\
\text { perate conmmu- } \\
\text { nity }\end{array}$} & Okaba community II & $\begin{array}{l}\text { Tsushima Current } \\
\text { Core Water }(e x \mathrm{NW} \\
\text { Pacific Central } \\
\text { Water })\end{array}$ & \multirow{2}{*}{$\begin{array}{l}\text { Upper Water } \\
\text { system }\end{array}$} \\
\hline & $\left\{\begin{array}{l}\text { Okaba community III } \\
\text { Okaba community IV }\end{array}\right.$ & $\left.\begin{array}{cc}. . & ? \\
& \text { Japan Sea Central } \\
\text {.- Water (ex winter } \\
\text { Upper Water) }\end{array}\right\}$ & \\
\hline \multirow[t]{2}{*}{$\begin{array}{l}\text { Deep-w ater } \\
\text { boreal to arctic } \\
\text { community }\end{array}$} & $\left\{\begin{array}{l}\text { Taraba community I .. } \\
\text { Taraba community II .. }\end{array}\right.$ & $\begin{array}{l}. . \\
\text { Intermediate } \\
\text { Water (ex winter } \\
\text {. Southern Lower } \\
\text { Water) }\end{array}$ & \multirow[t]{2}{*}{$\begin{array}{l}\text { Lower Water } \\
\text { system }\end{array}$} \\
\hline & Taraba community III.. & $\begin{array}{l}\text { Northern Lower } \\
. \text { Water }(=\text { Deep and } \\
\text { Bottom Waters })\end{array}$ & \\
\hline
\end{tabular}

The correlation inferred above between respective water masses and animal communities, especially the demersal ones, may be corroborated by optimum tempcrature data known for some representalive spccies of respective communities, which are shown in Table 7. The optimum tcmperature range of each member of a certain community falls within or covers the thermal rarge of the corresponding water mass. Further it is noticed that, so far as the temperature data are concerned, the center of the optimum life for the animals of the okaba community III seems to be in the range intermsdiate between the Tsushima Current Core Watcr and the Japan Sea Gentral Water; rather this can be expressed as "the members of the okaba ccmmunity III inhabit the water that may be called the upper peripheral portion of the winter Upper Water mass" against the members of the okaba community IV which inhabit the Japan Sea Central Water, i.e., the core water of the same water mass. 
Similarly, the animals of the tar aba community I are considered to inhabit principally the upper peripheral portion of the Southern Lower Water mass against the animals of the taraba community II which inhabit the Intermediate Water, i.e., the core water of the same water mass. As to the salinity, on the other hand, the upper peripheral portions of both the Upper and Southern Lower Water masses are some-

Table 7. Optimum temperature ranges (in ${ }^{\circ} \mathrm{C}$ ) for some representative species of animal communities found in the Japan Sea.

(After various authors).

\begin{tabular}{|c|c|c|c|}
\hline \multicolumn{4}{|c|}{ A) OKABA I AND CORRESPONDING PELAGIC COMMUNITIES } \\
\hline${ }^{*}$ Coryphaena hippurus & $24-26$ & Microcanthus strigatus & $22-25$ \\
\hline *Katsuwonus pelamis & $20-24$ & Goniistius zonatus & $18-26$ \\
\hline *Makaira mitsukurii & $19-24$ & Stephanolepis cirrhifer & $18-25$ \\
\hline${ }^{*}$ Cypselurus opisthopus hiraii & $20-23$ & *Auxis tapeinosoma & $19-23$ \\
\hline *Seriola quinqueradiata (young) & $18-24$ & *Engraulis japonica & $17-24$ \\
\hline Triakis scyllia & $18-22$ & Anthocidaris crassispina & $18-24$ \\
\hline Octopus vulgaris & $20-25$ & *Doryteuthis kensaki & $19-25$ \\
\hline \multicolumn{4}{|c|}{ B) OKABA II AND CORRESPONDING PELAGIC COMMUNITIES } \\
\hline *Pneumatophorus japonicur (young) & $14-21$ & ${ }^{*}$ Etrumeus teres & $13-21$ \\
\hline Trachurus japonicus & $15-20$ & * Thinnus thynnus & $14-19$ \\
\hline * Seriola quinqueradiata (medium) & $15-18$ & Eopsetta grigorjewi & $15-18$ \\
\hline *Cololabis saira & $13-19$ & ${ }^{*}$ Regalecus russellii & $12-19$ \\
\hline Tanakius kitaharai & Around 15 & Lepidotrigla microptera & Around 15 \\
\hline Chrysophrys major & $15-16$ & *Todarodes pacificus & $12-18$ \\
\hline \multicolumn{4}{|c|}{ C) OKABA III AND CORRESPONDING PELAGIC COMMUNITIES } \\
\hline *Pneumatophorus japonicus (adult) & $12-16$ & *Sardinops sagax melanosticta & $13-15$ \\
\hline * Seriola quinqueradiata (adult) & $13-15$ & Hexagrammos otaki & $10-14$ \\
\hline Ammodytes personatus & $9-13$ & Hemicentrotus pulcherrimus & $12-16$ \\
\hline Stichopus japonicus & $10-15$ & ${ }^{*}$ Doryteuthis bleekeri & $12-15$ \\
\hline \multicolumn{4}{|c|}{ D) OKABA IV AND CORRESPONDING PELAGIC COMMUNITIES } \\
\hline Glossanodon semifasciatus & $8-13$ & *Watasenia scintillans & $7-12$ \\
\hline *Parathemisto japonica & $5-13$ & *Euphausia pacifica & $5-12$ \\
\hline \multicolumn{4}{|c|}{ E) TARABA I COMmUnity } \\
\hline Pleurogrammus azonus & $5-8$ & Sebastes taczanowskii & $5-8$ \\
\hline Clupea harengus pallasi & $4-7$ & Glyptocephalus stelleri & $4-6$ \\
\hline Cleisthenes pinetorum herzensteini & Around 5 & Strongylocentrotus intermedius & $4-7$ \\
\hline \multicolumn{4}{|c|}{ F) TARABA II COMMUNITY } \\
\hline Theragra chalcogramma & $2-5$ & Arctoscopus juponicus & $2-5$ \\
\hline Sebastes owstoni & $2-5$ & Gadus morhua macrocephalus & $2-4$ \\
\hline Hipp?glossoides dubius & $1-5$ & Chionoecetes opilio & $1-5$ \\
\hline \multicolumn{4}{|c|}{ G) TARABA III COMMUNITY } \\
\hline Breviraja smirnovi & $0-2$ & Allolepis hollandi & $0-1.5$ \\
\hline Chionsecetes joponicus & $0-2$ & Pandalus borealis & $0-1.5$ \\
\hline
\end{tabular}

* It is intended to gather the data of demersal species as far as possible, but they are so limited that the data of some non-demersal species, which are pelagic or neritic and are shown with an asterisk, are given here supplementarily. 
what less haline than the typical water of respective water masses, as will be shown later (p. 101). Broadly speaking, the peripheral water is ephemeral in both cases, being formed in an early transient phase of the winter cooling and salinity concentration. The fact mentioned previously that the members of the demersal communities of okaba III and taraba I are originally coastal and adapted to lower salinity (pp. 377 \& 379 of Part III), and then characterized each by a marked seasonal vertical migration or a very extensive vertical range (pp. 377-379 of Part III and p. 339 of Part IV) seems to be related with the nature of these water masses that they are initially of lower salinity and show prominent seasonal fluctuations in both vertical extent and properties (see p. 101 of this paper).

The reason for the peculiar situation that the distinct demersal communities correlated with the peripheral water portions are defined respectively for the Upper Water and Southern Lower Water masses but no corresponding communities for either of the Superficial Water, Tsushima Current Core Water and Northern Lower Water masses may be sought in the fact that only the first two water masses are formed within the Japan Sea through a gradual process of cooling and salinity concentration in the period from autumn to winter, thus permitting the development or maintenance of distinct animal communities adapted to the transient phase in the formation of respective water masses. Meanwhile, the Superficial Water and Tsushima Current Core Water are both allothigenic to the Japan Sea, being brought there respectively as a "ready-made" water mass, and the Northern Lower Water is formed within the Japan Sea but under a narrowly constant condition at the freezing of sea water; thus, there seems to be no possibility for these three water masses to have any distinct peripheral portions or transient phases and therefore any definite animal communities correlated with them.

In physical oceanography, the Northern Lower Water is generally subdivided into the Deep and Bottom Water masses. Although the Bottom Water is usually slightly lower in temperature and higher in salinity than the Deep Water, their hydrographic characteristics are so close to each other that, biologically, these two waters are seemingly almost identical, without any definable qualitative differentiation being noted between the animal communities maintained at the levels of those water masses (pp. 381-384 of Part III). Only the fact that the taraba community III becomes poorer below ca. $1000 \mathrm{~m}$ (p. 384 of Part III) and also the pelagic community at the levels of the above demersal community is similarly considerably poorer below $1000 \mathrm{~m}$ (p. 344 of Part IV) might be related with some hydrographic differences between the Deep and Bottom Water masses, as the $1000 \mathrm{~m}$ level corresponds roughly with the transitional depth from the Deep Water to the Bottom Water.

As shown above, the pelagic communities of the Japan Sea are divisible into three groups according to the vertical distribution and the bio-climatological characters of their constituent species. This means a correspondence to the hydrographic stituation that there are three water systems definable in the Japan Sea, as mentioned already (p. 73). Of these, the Superficial Water system is unique in its temporal formation limited to the summer season (cf. Fig. 35), while the other two water systems are permanent in the Japan Sea, though their hydrographic properties and distributions are somewhat changed with seasons. The latter two water systems are, however, 
quite distinct from each other. The Upper Water system belongs to the warm water while the Lower Water system to the cold water. The boundary between them is sharply demarcated at about the constant level throughout the seasons and areas as far as these two water systems are defined; this boundary is the so-called "secondary" or "permanent" thermocline against the "first" or "seasonal" thermocline developed very sharply but temporarily at the bottom of the Superficial Water system during the summer season.

The understanding of the various zoogeographical aspects characteristic to the Japan Sea will be made properly only when the interrelations between the animal communities and the water masses are taken into consideration. Several examples in this line are given below:

(1) The vertical situation of respective animal communities and its geographical variation (Section 3.11). These are in a close approximation to the stratification of respective water masses and its geographical variation in the Japan Sea.

(2) The vertical segregation of northern and southern elements (Section 3.9). The boundary between their vertical ranges, either of the bottom or pelagic organisms, corresponds to the contact plane of the Lower Water system with the Upper Water system, namely the permanent thermocline, in the southeastern region of the sea and to that with the Superficial Water system, namely the seasonal thermocline, in the northwestern region. In this way, an easy comprehension will be made of the fact that the majority of the southern elements persist to flourish at shallower levels throughout the year in the southeastern region, while in the northwestern region the southern elements are mostly seasonal, flourishing in any degree only during the summer season (p. 372 of Part III).

(3) The boundary zone between the okaba and taraba gounds (p. 338 of Part IV). This is nothing but the level of the permanent thermocline. Owing to the perennial formation of this thermocline roughly at the constant depth, the zone around this level constitutes an important persisting "ecotone" between the two environments, and as a result of this many members of the different animal communities respectively of distinct climatological characteristics, i.e., the okaba III, okaba IV and taraba I, will appear in close contact in this limited space.

(4) The northern periphery of the distribution of southern elements (Section 3.1 and p. 88 of Part II). This is taken as corresponding to the Polar Front which demarcates the northern limit of the Upper Water system, i.e., the Upper Water mass in winter and the Tsushima Current Core Water and the Japan Sea Central Water masses together in summer (Fig. 36). Similarly, the occurrence area of the massive blooming of Coscinodiscus wailesii and other subtropical oceanic diatoms in winter to early spring (Fig. 16 in Part II) is explained as corresponding to the domain of the Upper Water.

(5) Occurrences of southern elements in the northern area. The southern elements that often penetrate into the area north of the Polar Front are mostly either 
the members of the tropical-subtropical surface pelagic community or those of the okaba bottom community I with a pelagic larval phase (pp. 329-330 of Part IV). This reflects the situation that the Superficial Water mass spreads northward beyond the Polar Frontal zone in the summer season (cf. p. 94 of this paper).

(6) Occurrences of neritic animals in the offshore region (Section 3.3). This is seemingly intimately correlated with the extension of the Superficial Water of much lower salinity far to the offshore region of the Japan Sea in the summer season. This relation is especially prominent between the development of a pelagic community consisting of very strongly neritic elements in the northwestern part of the sea (p. 87 of Part II) and the formation of the markedly diluted Northwest Superficial Water mass in the same region (cf. pp. 93-94 of this paper).

(7) Distinctiveness of the deep water fauna (Sections 3.12 \& 3.13). The fauna on the deep floor of the Japan Sea, represented by the taraba community III, consists of the inhabitants of the Northern Lower Water which is authigenic in the Japan Sea and quite distinct from the deep water of the Pacific as mentioned already (p. 75). Naturally, then, the deep bottom fauna of this marginal sea is decidedly diffcrent from that of the Pacific and entirely composed of the species of arctic origin or having a close affinity with arctic species, which are adapted to much lower water temperature than those inhabiting the deep bottom of the Pacific. The same is true as to the deep pelagic fauna of the Japan Sea, too (p. 344 of Part IV; also, Vinogradov 1968).

\subsection{Movement and Transformation of Water Masses and the Migrations of Animal Populations}

In this section, the characteristics of animal distribution in respective seasons in the Japah Sea will be mentioned dynamically with close reference to the hydrography. Descriptions are begun with the winter aspects.

\subsubsection{Winter to Spring Aspects}

Though the hydrographic features of the Japan Sea in the warm : easons are fairly well known, those, especially the circulation pattern of watcr, in the winter season are not yet worked out well and are largely obscure, because of the severe condition imposed by the northwest monsoon which prcvails very prominently throughout the winter months.

The most outstanding feature of the animal distribution in this season is the coastward drift and subsequent stranding of many pelagic animals along the southeastern coasts of the sea; the bulk of the stranded animals are southern elements (Section 3.2) and the rest are of the northern coastal origin (Section 3.6). This suggests the prevalence of a powerful southerly surface current in the Japan Sca in winter, which is no doubt a kind of drift currents induced by the northwest monsoon. As a whole, the surface current system of this marginal sca in winter scason is supposed to be directed approximately from north to south, at least during the time when the monsoon wind is blowing. 
Next, the facts that the stranded southern animals include not only the surface pelagic species but also several mesopelagic species (Section 3.5) and moreover that many bathypelagic plankton animals are brought up in mass from deeper layers to be drifted toward the south from late winter to spring (pp. 81-83 of Part II) indicate that a vertical mixing of water of a large scale is induced to a considerable depth of the sea in this season, and this brings the meso- and bathypelagic animals up to the surface layer to enter the influence of the monsoon. At the same time, some of the epipelagic animals inhabiting the surface layer are naturally brought down to deeper levels by this vertical mixing, as Meshcheryakova (1960) found not a few of the surface warm-water plankton animals in the depths below $200 \mathrm{~m}$ in the southeastern region of the sea (p. 90 of Part II). Apparently, this vertical mixing is a kind of thermohaline convection caused by the surface chilling and evapolation greatly accelerated by the monsoon. Such horizontal and vertical water movements seem to take place in the surface and upper layers almost over the entire area of the Japan Sea throughout the winter season.

On the basis of the above-given suggestions and the distribution pattern of water masses outlined in Fig. 36a, the winter circulation system of water in this marginal sea is proposed here schematically in Fig. 37 . In constructing this qualitative model, a special attention is laid on the point that in the winter season the influx of the Tsushima current into the Japan Sea dwindles steeply, hardly sustaining the volume transport not more than $10 \%$ of that in late summer on the average (SUDA 1938; MrYAZAKI 1952) and the sea is as a whole under a "stagnant" phase (MrYazaki \& ABE 1960) so that it may behave as if it were a stratified lake under the stress of wind. The marked prevalence of horizontal mixing in the shallow layers both within the Tsushima current area (=the Upper Water area in my definition) and the Liman current area (=the Southern Lower Water area) in the winter season as suggested by Miyazaki \& Abe (1960) seems to be largely due to the surface drift currents mentioned above. Penetration of the Southern Lower Water beneath the Upper Water mass at the Polar Front is already supposed by UDA (1938) in connection with the general circulation of the "cold deep water" of the Japan Sea. The flows $X_{1}$ and $X_{2}$ in the vertical section $a$ in Fig. 37 are the return currents going from south to north respectively along the bottom of the Upper Water mass and the bottom of the Southern Lower Water mass; their developments are natural from the view-point of continuity and equilibrium of water movement (MORTIMER 1951, 1952, 1954; etc.) The direction of circulation of the Northern Lower Water is just opposite to those of the Southern Lower Water and the Upper Water; namely, it is directed to the north just below the bottom of the Southern Lower Water mass ( $\mathrm{X}_{3}$ in Fig. $37 a$ ) but southward at deeper levels. This is suggested after the theory of Fukuoka (1965, pp. 100-101), assuming that the geostrophic flow approximation is valid within the Northern Lower Water mass and taking into account the vertical movement of this water supposed just below. In the northwestern half of the sea, the Northern Lower Water upwells to 

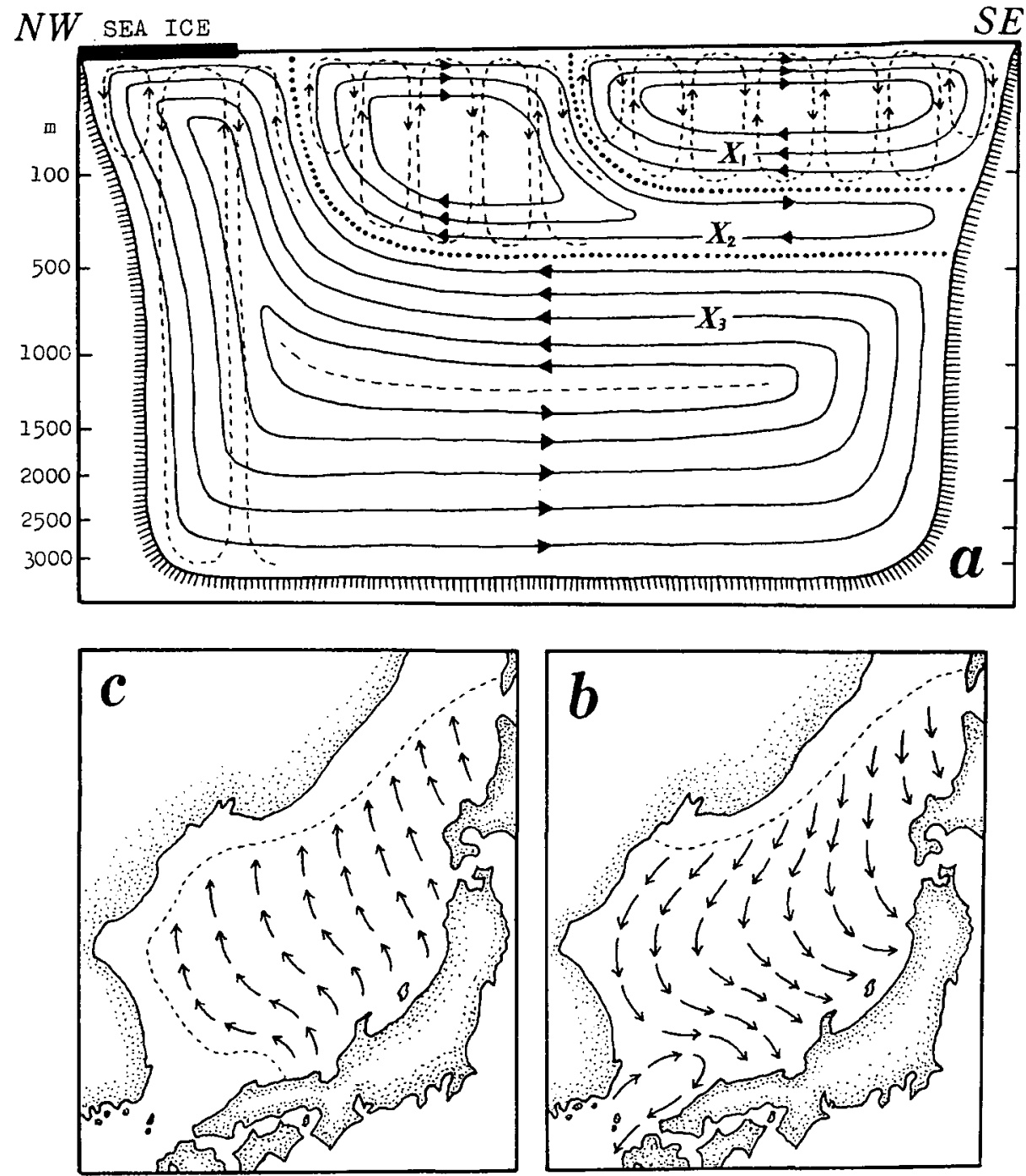

Fig. 37. Proposed winter circulation pattern in the Japan Sea.

The vertical pattern $(a)$ is shown in a NW-SE section through the center of the sea. The broken curves schematically indicate the convection, the solid curves the general aspect of advection currents, and the dotted curves the boundaries between the Upper Water, Southern Lower Water and Northern Lower Water masses. The broken line shown in the middle of the Northern Lower Water mass indicates the supposed boundary between the Deep Watcr and Bottom Water masses. See also Fig. 36a.

The horizontal circulation pattern is given respectively as to the south-flowing layer $(b)$ and the north-flowing layer $(c)$ in the sea. The former pattern is seen generally over the whole sea surface, partly just below the bottom of the Upper Water mass, and furthr deep near the sea floor, though the flow is much weaker and in somewhat modified fashions in deeper layers. On the other hand, the latter pattern representing the return currents is seen in the lower layers of the Upper and Southern Lower Water masses and in the upper layers of the Northern Lower Water mass. These north-flowing return currents are indicated in figure $a$ by $X_{1}, X_{2}$ and $X_{3}$, respectively. The broken lines in $b$ and $c$ show the supposed limit of respective current systems. 
shallower layers probably with gradual acceleration; this upwelling is inevitable if the Bottom Water is formed and sinks down out of the surface layer in the northwesternmost region of the sea (p. 75 of this paper). After the upwelling, the water will possibly keep the northwestward flow under the sea ice covering along the Siberian coast and gradually be chilled and concentrated of salinity finally enough to sink down as the Bottom Water fairly rapidly at first but gradually slowly later.

The winter distribution pattern of every water mass in the Japan Sea seems to be deducible from the circulation system outlined above ${ }^{3)}$.

Now, several biological phenomena other than those mentioned previously (pp. 81-82 of this paper) are explained comprehensively on the above-mentioned circulation system of water.

First, from late winter to spring large populations of the pelagic amphipod Parathemisto japonica are found distributed just south of the Polar Frontal zone and afford the shoals of the pink salmon Oncorhynchus gorbuscha migrating northward the most important nutrition (FUKATAKI et al. 1961). The amphipod populations are supposed to have been transported there by the northerly return current along the bottom of the Upper Water mass $\left(\mathrm{X}_{1}\right.$ in Fig. 37a) from their natal place possibly in the southeastern area of the Japan Sea and accumulat ed in the surface layer just south of the Polar Front. As mentioned previously (p. 83 of Part II), large individuals of Parathemisto are found only in the deeper layers in the southeastern area of the sea, and it is a well known fact that the amphipod found near the Polar Frontal zone is also very large and bulgy. More or less similar phenomena may be assumed as to certain members of the okaba community IV inhabiting the lower portion of the Upper Water mass or the Japan Sea Central Water mass, e.g. the euphausiid Euphausia pacifica and the teleost Maurolicus muelleri (cf. pp. 330-331 and pp. 335-336 of Part IV).

Secondly, not a few members of the subarctic-arctic zooplankton including abyssopelagic forms and mostly of immature stages, are frequently found in the plankton samples collected or in the stomach contents of fishes caught below the 150-200 m level in the southeastern area of the Japan Sea; among those are the appendicularian Oikopleura labradoriensis, the crustaceans Thysanoessa longipes, Euprimno macropa, *Meterythrops spp., Calanus cristatus, Eucalanus bungii bungii, Pareuchaeta elongata (=P. japonica), *Conchoecia spp., the pteropod Clione limacina, the ctenophore *Beroe sp. beautifully colored red, the siphonophore $*$ Dimophyes arctica, etc. Some of these are considered

3) The surface circulation pattern supposed above (Fig. 37b) is quite different from those hitherto deduced from the dynamic computation; for instance, compare with the scheme presented by Sizova (1961). It is very incredible that any dynamic computation can be successfully applied to clarify the winter circulation in the upper layers of the Japan Sea, which are influenced so strongly by the monsoon. In this respect, reference should be made to Hidaka (1957). On the contrary, the circulation model presented here resembles considerably UDA's (1950) scheme which was constructed by taking into account the wind stress of the monsoon and further corroborated by the results of drift bottle tracing. NisHida $(1935,1955)$ also suggests a similar winter circulation pattern from the analysis of the data of drift bottle experiments. 
to inhabit the Southern Lower Water, while others marked by an asterisk are seemingly from the Northern Lower Water (p. 344 of Part IV). They are probably brought up by the convection currents to surface layers, drifted southward to the Polar Frontal zone, and then carried beneath the Upper Water mass by submerging currents ultimately to arrive at deeper levels off the west coast of Honshu Island.

Similar southerly transport of some other plankton animals of the Southern Lower Water is quite reasonable as seen in the cases of the copepod Calanus plumchrus, the chaetognath Sagitta elegans, the pteropod Limacina helicina and the trachymedusa Aglantha digitale; however, all being represented by young individuals, they are able to penetrate into and to keep the shallow-level drift in the warmer Upper Water mass, possibly because of their boreal nature and higher adaptability to the warm water than in the afore-mentioned arctic-subartic zooplankters collected solely from deeper levels within the Southern Lower Water.

FUruhashi (1953) mentions that the upper limit of vertical distribution of those boreal zooplankters is found approximately near the isotherm of $11^{\circ} \mathrm{C}$; this seems to show that the rise and drift of these zooplankters are done within the lower portion of the Upper Water mass, or the Japan Sea Central Water mass ${ }^{\circ}$ with the temperature range $9-11^{\circ} \mathrm{C}$. As mentioned previously (pp. 74-75 of this paper), the Upper Water mass is replaced with the Peripheral NW Pacific Central Water (Tm'), a water mass somewhat warmer and more haline, off the San'in coast of west Honshu, and this seems to prevent the mass rise of the boreal bathypelagic zooplankters in this area in early spring (p. 89 of Part II). No data are available as to the temperature range of the arctic-subarctic zooplankters, but the upper limit seemingly never exceeds $7-8^{\circ} \mathrm{C}$.

- Since the arctic-subarctic or boreal zooplankters belonging to the Lower Water masses must travel over more or less considerable distance to reach the Polar Front and submerge under or penetrate into the Upper Water mass, their appearances in or near the coastal waters of Honshu Island are naturally later than those of the zooplankters such as Parathemisto japonica and Euphausia pacifica inhabiting the lower portion of the Upper Water mass itself or the Japan Sea Central Water. This time lag is well reflected in the stomach contents of plankton-feeding fishes such as the chub mackerel caught near the bottom around the edge of the continental shelf off the west coast of Honshu as referred to already (p. 90 of Part II). In this area, until middle March when the arctic-subarctic, and especially boreal, zooplankters mentioned above begin to appear in quantities, the plankton of the shallow layers is composed of the warm water, mainly subtropical, species although the water temperature has already dropped to the annual minimum in early March (loc. cit.). Of course, these subtropical plankton species are the inhabitants of the Upper Water mass, having survived the winter condition there.

The young individuals of the arctic-subarctic zooplankters having submerged below the Upper Water mass to penetrate toward the west coast of Honshu may be caught by the northerly return currents in the middle layers $\left(\mathrm{X}_{2}\right.$, and probably together with $\mathrm{X}_{3}$, in Fig. 37a) eventually to be carried back to their natal place in the northern parts of the Southern Lower Water or the Northern Lower Water 
mass; their life cycle seemingly conforms to such a tour. This may be the reason why the adult stages of those zooplankters are hardly found in the southeastern area of the Japan Sea in spite of the fact that their juveniles are frequently and sometimes abundantly found there.

Lastly, the "sublittoral faunas" supposed to inhabit respectively the upper portions of the Upper Water and Southern Lower Water masses, i.e., the okaba community III and the taraba community I (pp. 377-379 of Part III, pp. 78-80 of this paper), may not insignificantly be affected by the circulation system as suggested above. It is natural that the warmer, less haline water formed in the early transient phase or situated in the upper layers of the southern parts of respective water masses is conveyed leeward to the southern coastal areas of the Japan Sea, covers the continental shelf or slope, and affords there suitable environments for the temperate and subarctic sublittoral faunas. Thence, the okaba community III is especially well flourishing in the coastal areas surrounding the southern Japan and southern Korea (p. 336 of Part IV), and the taraba community I, particularly its group 2, penetrates into moderate depths in the waters off the coasts of both northern and southern ends of Honshu Island along the west Hokkaido and east Korea, respectively (pp. 337-338 of Part IV). In spring, as discussed later in detail (p. $89 \mathrm{ff}$.), the water of shallower layers of respective water masses will spread northward over the Northern Lower Water mass and fill the shallow coastal areas of the northern and northwestern regions of the sea, affording a suitable circumstance for both temperate and subarctic sublittoral faunas there (pp. 339-340 of Part IV).

On the other hand, the bulk of the colder, more haline water of deeper layers of both the Upper Water and Southern Lower Water masses flows respectively northward ( $\mathrm{X}_{1}$ and $\mathrm{X}_{2}$ in Fig. 37a) finally to up-well in the central region of the Japan Sea, never reaching any coastal areas. It is thus reasonable that in principle only pelagic populations are sustained in these water portions, whereas demersal or meropelagic ones cannot persist in them for any significant duration. This may be one of the reasons for the fact that the bottom communities okaba IV and taraba II, respectively correlated with the deeper portions or the final-phase products of the Upper Water and Southern Lower Water masses, include not a few species which show a marked tendency to pelagic life (for example, Maurolicus muelleri, Watasenia scintillans, Euphausia pacifica, etc. in okaba IV and Theragra chalcogramma, Sebastes owstoni, etc. in taraba II), while the communities okaba.III and taraba I, respectively correlated with the upper portions or the transient-phase products of the same two water masses, consist solely of the species with an entirely demersal habit at least throughout the adult stage, hence their distinctive "sublittoral" nature.

In this connection, it is also interesting to note that the more pelagic members of the okaba community IV can stand lower temperature than the more demersal members of the same community. For example, the "pelagic" Maurolicus muelleri, Euphausia pacifica, Parathemisto japonica, etc. can live in the water considerably colder than that in which the "demersal" Glossanodon semifasciatus, Pasiphaea sivado, ect. are usually living. As a result, the former are able to penetrate down to the levels considerably deeper than the level of the edge of the continental shelf at which the latter live limitedly (pp. 335-336 of Part IV). It is not impossible that the adaptation of the above-mentioned pelagic members to lower temperature might be accelerated by being caught by the return current at the deeper levels of their living water mass, which may carry them into the colder environments every winter. A similar relation seemingly exists, too, between the more pelagic and more demersal members of the 
taraba community II (compare, for instance, Theragra chalcogramma and Gadus morhua macrocephalus), although the pertinent data are available only scarcely.

The transition from spring to summer is perceivable in the Japan Sea by the gradual decrease of the afore-mentioned boreal bathypelagic zooplankters in the surface layers. The decrease takes place around April to May in the southeastern, May to June in the northeastern, and around June to July in the northwestern region
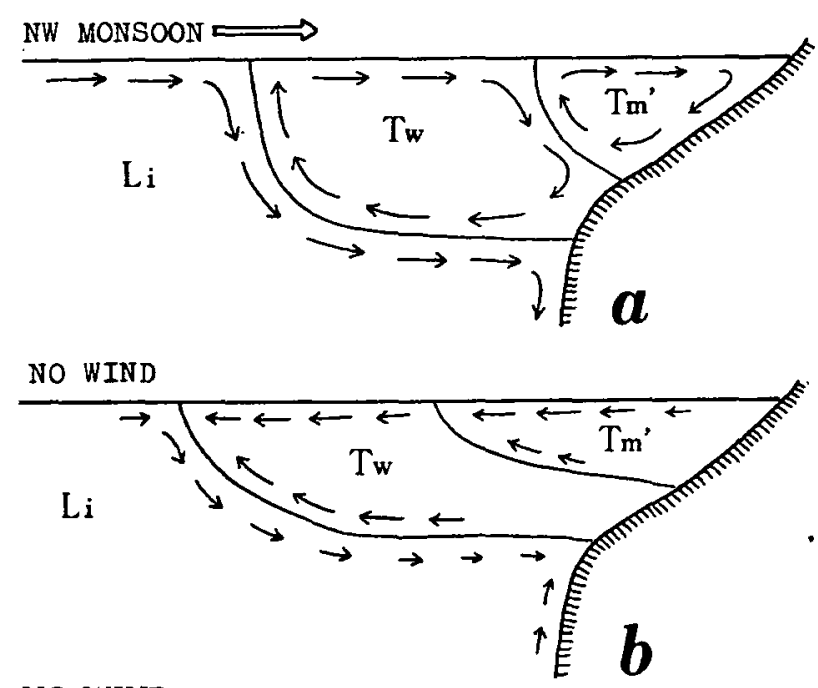

NO WIND

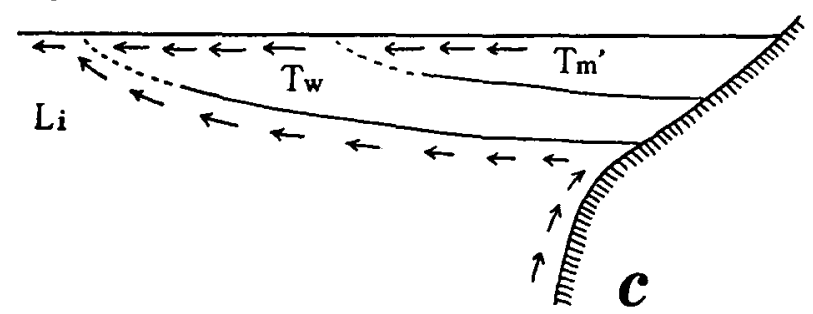

Fig. 38. Changes in the vertical circulation pattern from winter to spring, shown in the N-S section off the coast of western San'in District, Honshu Island. $a$-In midwinter, when the northwest monsoon is prevailing; $b$-In early to middle spring, when the northwest monsoon has ceased; $c$-In late spring.

The arrows indicate the general direction of currents.

Tm'-Peripheral Northwest Pacific Central Water mass;

Tw-Upper Water mass; $\mathrm{Li}$-Southern Lower Water mass.

of the sea; thus, a time lag from southeast to northwest is evident (p. 86 of Part II). With the decrease of the boreal zooplankton, some warm-temperate neritic plankters such as Noctiluca scintillans, Calanus sinicus, Paracalanus parvus, Oithona nana, Corycaeus affinis, Sagitta bedoti, Salpa fusiformis, etc. (loc. cit.) increase gradually in the southeastern 
Japan Sea to form at last a quite different pelagic community. As many of the above species are main constituents of the plankton off northwest Kyushu throughout the season from December to April (Enомoto 1957; Senta 1958; TANAKA \& Koga 1958), their appearance in the southeastern Japan Sea is accepted to show that the Peripheral NW Pacific Central Water mass confined to the south of the western San'in District (cf. Fig. 31) from winter to spring is now spreading north toward the central region of the sea, together with organisms contained in it, driving the Upper Water mass away to the north or partly lapping it over. The Upper Water mass itself then moves northwestward and spreads over the Lower Water masses (Fig. 38). This northerly movement of the Upper Water mass may bring about a gradual disappearance of the boreal zooplankters having penetrated into and been predominating in it such as Calanus plumchrus, Sagitta elegans, Aglantha digitale, etc. and the mesopelagic ones belonging to the Upper Water itself such as Parathemisto japonica, Euphausia pacifica, Metridia pacifica, etc. from the shallow layers off the west coasts of Honshu and later of Hokkaido in late spring to early summer. All these plankton animals are, then, found thriving in the upper layers of the central and northwestern regions of the Japan Sea in early to middle summer and constitute the important food items for plankton-feeders such as sardine and chub mackerel (NAKaI 1942a, 1942c) and squid (OkiYama 1965) migrating there. According to NaKaI (1942b), the plankton biomass in the upper $150 \mathrm{~m}$ is much greater in the northwestern region than in the southeastern region of the Japan Sea during the season from April to October, especially from May to July, and this is a reversal of the condition found in the winter season. Possibly, the early-summer increase of plankton biomass in the northwestern region of the Japan Sea principally due to abundant occurrences of Calanus plumchrus and Sagitta elegans (NAKaI op. cit.) is achieved, partly at least, by the addition of the populations previously maintained in the Upper Water mass and carried there by its northerly spreading mentioned above. For these reasons, the surface occurrence of the boreal bathypelagic zooplankters will continue much longer in the northern region than in the southern region of the sea (p. 86 of Part II).

Then, what is the mechanism of the northwest spreading of both the Peripheral NW Pacific Central Water and Upper Water masses? In my opinion, the winter distribution pattern of water masses in the Japan Sea is maintained chiefly under the stress of the northwest monsoon; then, in March to April when the monsoon is dying and the sea is released from the stress, those water masses will begin to restore the equilibrium distribution, respectively spreading northwestward in a thin layer over the Lower Water masses of higher specific gravity. Hitherto it has generally been believed that the northward extension of the warmer water masses mentioned above is due to the increase of the warm Tsushima current flowing into the Japan Sea from the East China Sea. This explanation seems, to my opinion, to require some amendments, because in the first place the volume transport of the warm current into the Japan Sea through the Tsushima Straits is not markedly raised till June (Fig. 39), namely, two 
or more months after the beginning of the northward extension of the warmer water masses in the Japan Sea proper, and secondly the northward extension of the warmer water masses in question never assumes the jet-like streams invariably observed during the period of the strong influx of the warm Tsushima current but is performed in a diffused spreading, as shown by the northwestward drift of the boreal bathypelagic plankton and dispersal of the warm-temperate neritic plankton and more clearly, as mentioned below, by the seasonal migration pattern of some temperate fishes and baleen whales.

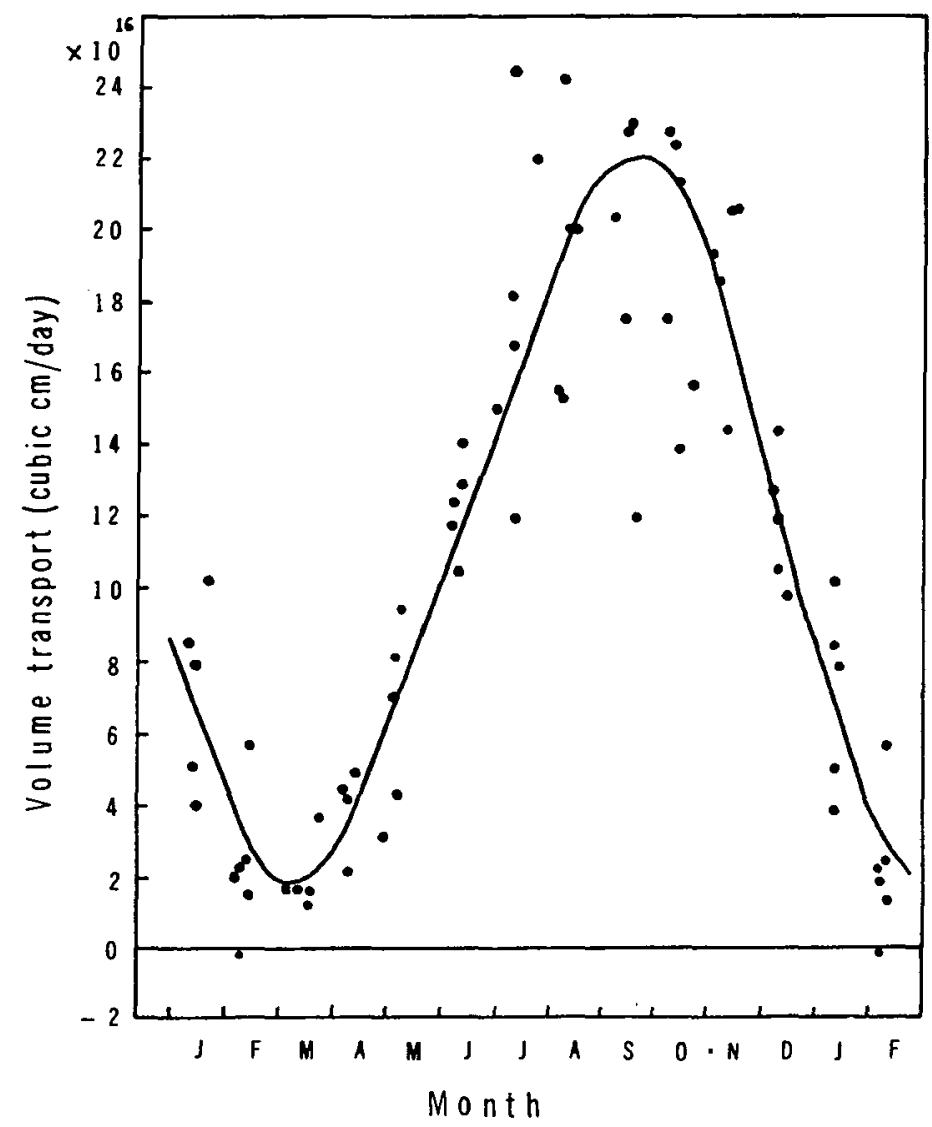

Fig. 39. Seasonal variation in the northward volume transport of the warm current through the Tsushima Straits. Dots are actual values observed in the years 1935-1940. (After Mryazak! 1952).

As discussed in Section 3.8 (pp. 90-95 of Part II), the migratory animals belonging to the group I usually winter in the areas of the Japan Sea west of Wakasa Bay and especially in the western waters of Kyushu, and start the northward migration in March to April; this seems to suggest that these animals are the inhabitants of the Peripheral NW Pacific Central Water mass and their northward migration conforms 
to the movement of that water mass. Their northward migration is unique in its much diffused aspect over an extensive area of the sea as compared with the similar migration of animals belonging to the other groups (Figs. 18-20 or Fig. 23-I of Part II). As a more concrete example of the migration of the type here concerned, Fig. 40 is presented to show the occurrence area of populations of the saury Cololabis saira by months from spring to summer. It is seen clearly that the migration of this teleost is very diffused, extending over a wide area, but as a whole gradually moving toward

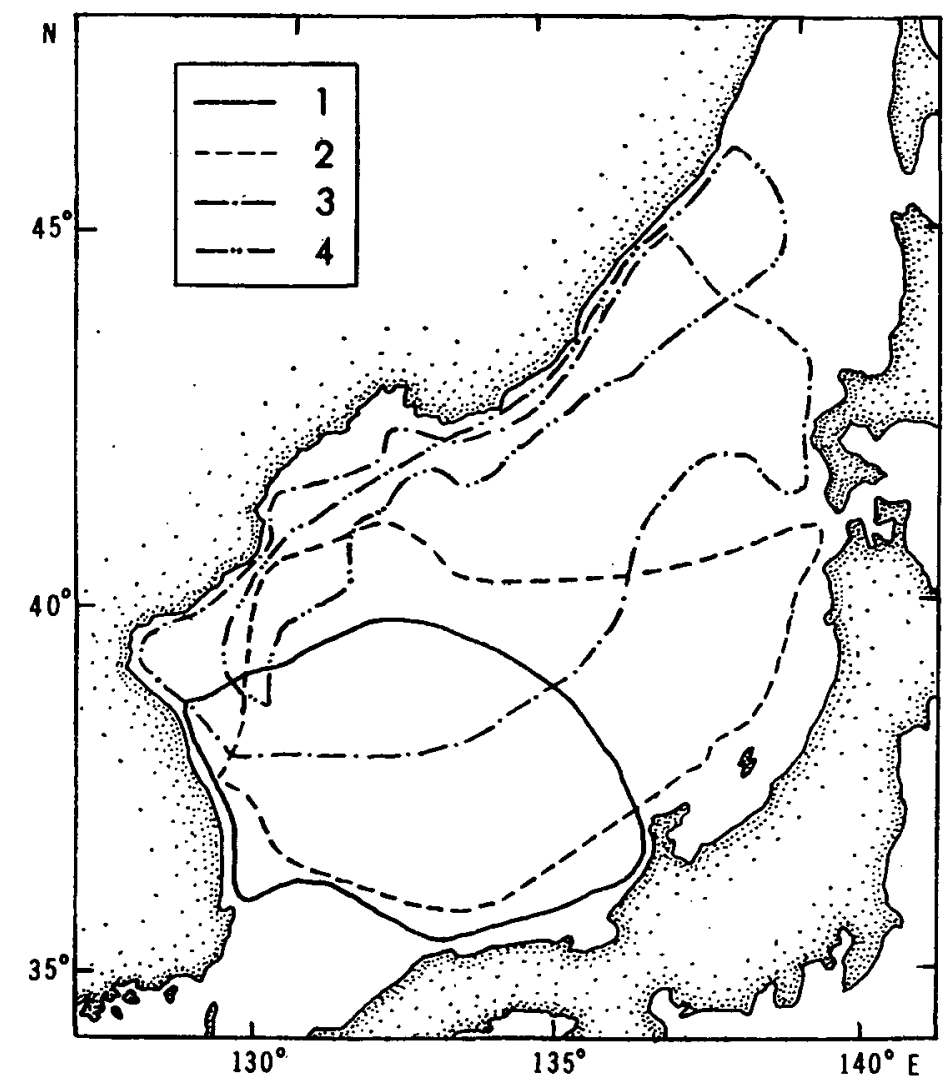

Fig. 40. Occurrence area of the saury Cololabis saira by months in its northerly migration period. 1-May; 2-June; 3-July; 4-August. (After APANOvich 1962; slightly modified on further data).

the northwestern region of the sea. It is especially noteworthy that the occurrence area in May is fan-shaped, with the pivot at the southern corner of the sea. The above-mentioned movement of the habitat of the saury supposedly belonging to the Peripheral NW Pacific Central Water seems strongly to suggest the diffusive spreading of that water mass from its source near the Tsushima Straits. The dispersed offshore occurrences of the more neritic teleost Fugu vermicularis porphyreus and the chaetognath 
Sagitta bedoti in early summer (pp. 60-65 of Part I) also seem to point to the same hydrographic succession.

Such a hydrographic situation as mentioned above is certainly a prelude to the strong influx of the warm current into the Japan Sea. As shown already, the core water of the warm Tsushima current is composed of the NW Pacific Central Water derived from the Pacific Ocean; and it is interesting to note that it is usually from June to July that some representative species of this water are caught in more or less significant numbers in the southeastern region of the Japan Sea. For instance, the oarfish Regalecus russellii shows a second peak of occurrence in this season off the coasts of San'in and Hokuriku Districts (Nishimura 1962b; Homna \& Krtami 1967. The first peak in winter; cf. pp. 69-70 of Part I), and the centrophid fish Ocycrius japonicus is caught in a considerable amount from inshore as well as offshore areas of the sea in the same season (NIshimura 1962a). Moreover, fishermen of certain districts in middle Japan such as Sado Island maintain that when Ocycrius shoals arrive the saruy shoals will disappear from the fishing ground; this is particularly interesting in that it suggests a replacement of the Peripheral NW Pacific Central Water mass to which the saury belongs with the core water of the warm current or the genuine NW Pacific Central Water mass taking place around middle or late June in the southeastern region of the Japan Sea.

\subsubsection{Summer Aspects}

The warm Tsushima current really increases its strength since June as seen in Fig. 39. At the same time, it shows a tendency to ramify; namely, the current tends to flow in two or more branches or stream belts defined fairly clearly (SudA \& Hidaka 1932; UDA 1934a). This is well reflected on the migration pattern of pelagic animals of group II (pp. 95-99 and Fig. 23-II of Part II); these animals, including the chub mackerel, yellowtail, bluefin tuna, etc., migrate northward from June to July along the offshore as well as inshore routes and they are found only rarely in the areas between the two routes. As shown by the migration pattern of these fishes, the water mass inhabited by them, which may properly be named the "warmed" Peripheral NW Pacific Central Water or the "initial" Superficial Water for its nature or fate, is considered to flow northward in a central and two (or more) coastal branches. Conversely speaking, the movement of the water mass in branches or compact belts may be taken as an indication of the increase of the warm current.

It is mentioned already (pp. 95-101 of Part II) that the later the northward migration of pelagic animals of group $I I$ begins, the greater the preference of the central offshore route to the coastal routes is. This is well exemplified by the adult schools of the bluefin tuna, and the young schools of both the yellowtail and the fregate mackerel, which all enter the Japan Sea through the Tsushima Straits in July to August or September. The retardation is culminated with the members of group III such as the porcupinefish Diodon holacanthus, ocean sunfishes Mola mola and Masturus lanceolatus, sea turtles Dermochelys coriacea and Eretmochelys imbricata, sea snake Pelamis (=Pelamydrus) 
platurus, etc., which enter the sea in September to October when the volume transport of the warm current attains the maximum. The occurrence patterns of the animals of group III in the Japan Sea are already fully discussed in pp. 53-57 of Part I and their supposed migration routes are shown in Fig. 23-m of Part II. Similar patterns and routes may also be applied to the tropical-subtropical pelagic cephalopods Thysanoteuthis rhombus and Argonauta argo (Nishimura 1966b, 1968a). The patterns of northward migration of these animals seem to indicate that the central offshore branch of the warm current is much stronger than the coastal branches in the peak of its inflow into the Japan Sea. This conforms to the physical estimation that approximately $70 \%$ of the volume transport of the warm current owes to the central offshore branch inflowing through the west channel of the Tsushima Straits (MrYazaki 1952).

Further, this central offshore branch of the warm current seemingly assumes a jet stream which is confined to a narrow belt and thus keeps its energy little dissipated during its long course. This may be one of the causes for the facts that the pelagic animals of group III are scarcely diffused during their northward migration into the inshore waters along the middle part of Honshu Island, and moreover that some small numbers of the animals of this group get to the west coasts of northernmost Honshu and southern Hokkaido considerably earlier than to the coast of middle Honshu (pp. 56-57 of Part I). When the northwest monsoon begins to blow and induce southward drift currents on the sea surface in late autumn, the bulk of the animal populations of group III are possibly still on their way to the north or remain in the central region of the sea (see p. 99 of this paper) so that they will be subject to these drift currents and be driven toward the west coast of middle to south Honshu for the following one or two months, frequently in large numbers. This is the mechanism of the curious phenomenon that the occurrences of many tropicalsubtropical pelagic animals in the southeastern coastal waters of the Japan Sea are confined almost exclusively in winter season (Section 3.2).

Concurrently with the intensification of the warm Tsushima current, a water of distinctively low salinity will cover an extensive area of the Japan Sea, offshore as well as inshore, from midsummer to autumn. The physical data seem to show that this low salinity water mass has originated mainly in the East China Sea and been driven into the Japan Sea by the warm current (Suda \& Hidaka 1932; Suda et al. 1932; UDA 1936). This notable extension of the diluted surface water, i.e. the Superficial Water, is well reflected in the distribution of many neritic or inlet water animals which are thriving not only in their proper environments but also in the offshore or exposed areas respectively of the Japan Sea in the said season (Section 3.3 and pp. 87-88 of Part II, pp. 373-376 of Part III). As to the origin of these offshoredistributed neritic populations, TokiokA (1951) expressed the opinion concerning the chaetognaths Sagitta crassa f. typica and f. naikaiensis and the appendicularian Oikopleura dioica found around the New Yamato Bank (now called the Oki Bank) about 
$120 \mathrm{~km}$ off the coast of San'in District that they might be the drift individuals carried there from the coastal waters around Korea including the Yellow Sea and the southern and eastern waters of Korean Peninsula, rather than from the coast of San'in District. The drift of the rhizostomaean medusa Stomolophus nomurai observed in summer to autumn 1958 (pp. 63-64 of Part I) also suggests that the low salinity water of the East China Sea is driven into the Japan Sea sweeping by the neritic area along the southern coast of Korea (Nishimura 1959a, 1961a).

In midsummer, the southeast wind predominates over the Japan Sea. Although it is never so strong as the northwest in winter, it may nonetheless have influence on the surface circulation of the Japan Sea by inducing north or northeast drift currents. Moreover, as seen in Fig. 34, a marked thermocline is developed at a very shallow level in this season, especially prominently in the northern to northwestern region. Such a stratification undoubtedly favors significantly the development of drift currents in the diluted Superficial Water above the thermocline, and this may naturally be more remarkable in the northern to northwestern half of the sea. Temporary occurrences of not a few tropical-subtropical animals, mostly epipelagic, off or on the west coast of Hokkaido in late summer (pp. 45-46 of Part I and p. 329 of Part IV) and similarly the prevalence of small neritic zooplankters (p. 87 of Part II) and occasional occurrences of warm-water migratory animals (pp. 45-46 of Part I and pp. 329-330 of Part IV) in the environs of Peter the Great Bay in the same season are partly attributable to the northerly drift of the Superficial Water.

The origin of the Northwest Superficial Water can seemigly be traced to the northerly drift of the coastal water along south Korea, though the contribution of the local drainage is not negligible. The presence of not a few neritic animals, such as the copepods Acartia steueri and Tortanus longipes, endemic to or locally restricted in the environs of Peter the Great Bay (BRoDsky 1950, 1957) is suggestive of the possibility that the Superficial Water in those environs is authigenic, partly at least (see p. 75 of this paper); it is very probable that in addition to the influx of the Upper Water and the Peripheral NW Pacific Central Water, both having originated in the southern region of the sea and extended north over the sea surface, the accumulation of the fresh water from thawing of sea ice and the warming by local insolation which increases from late March may be largely responsible for the initiation of the Superficial Water in this region. In fact, it is estimated that the net heat transfer from the atmosphere to the sea is very large in spring in the northwestern region of the Japan Sea (Mryazaki 1952). Further development of the Superficial Water will be much favored there, because the drainage is greatest in midsummer to early autumn as the bulk of annual precipitation is concentrated in summer months from June or July to September in southeastern Siberia and northeastern China (Arakawa 1942).

As mentioned already (pp. 333-335 of Part IV), the vertical range of the demersal okaba community I seen at the level of the Superficial Water mass is only half as 
thick off Niigata and Yamagata Prefectures, middle Honshu, as off San'in District of west Honshu. This indicates naturally that the water mass in question is reduced to half in its thickness in the course from the southernmost to the middle region of the eastern Japan Sea, as is shown by physical oceanographic data: Fig. 41 shows the distribution of the Superficial Water in two vertical sections respectively off Hokuriku District of middle Honshu and off San'in District of west Honshu, which
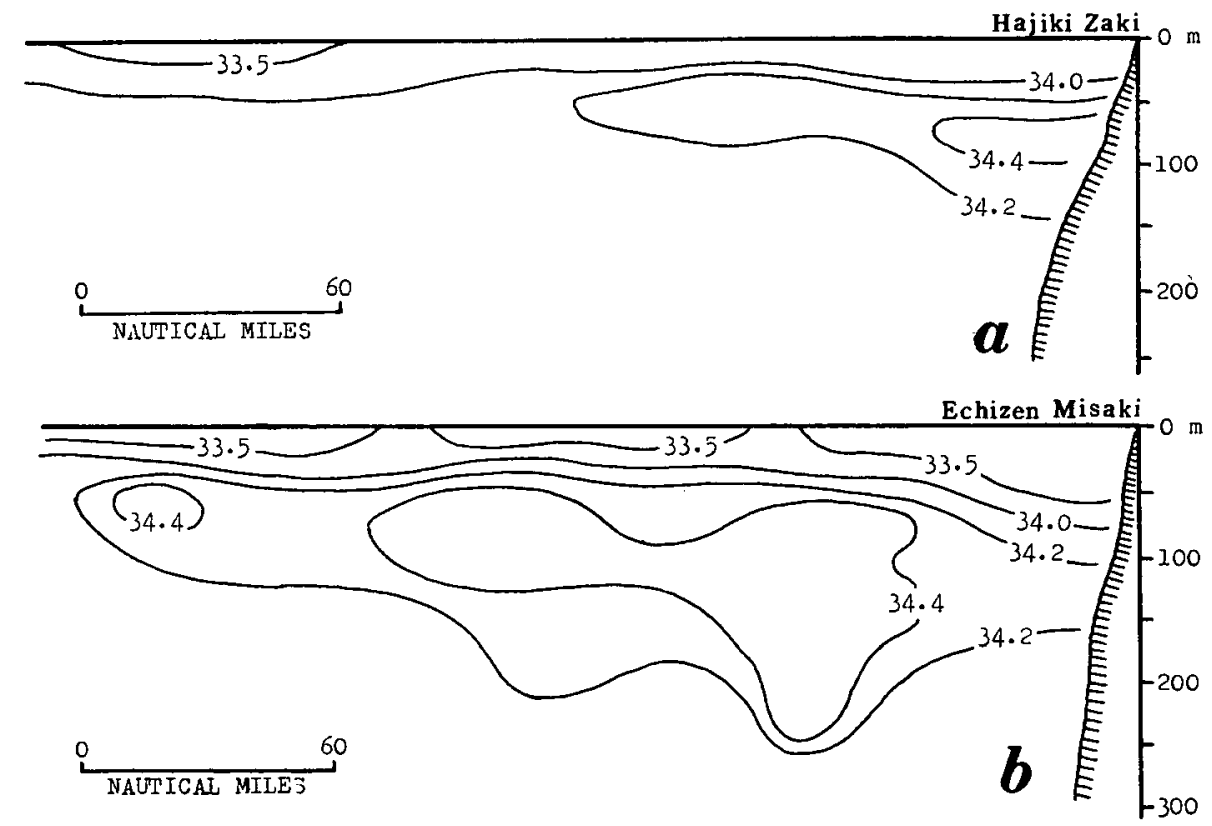

Fig. 41. Vertical distribution of salinity in $\%$ in two sections extending northwest from respectively Cape Hajiki Zaki $\left(38^{\circ} 21^{\prime}\right.$ N. Lat., $138^{\circ} 31^{\prime}$ E. Long.) in Hokuriku District, middle Honshu (a) and Cape Echizen Misaki (35 $58^{\prime}$ N. Lat., $135^{\circ} 57^{\prime}$ E. Long.) in San'in District, west Honshu (b). Based on the data obtained by the Maizuru Marine Observatory in August to September, 1966.

The Superficial Water with the salinity less than $34.0 \%$ is almost twice as thick off San'in District $(b)$ as off Hokuriku District $(a)$, and the Tsushima Current Core Water in the strict sense and with the salinity over $34.4 \%$ is much thicker and located much more offshore off the former than off the latter. The Tsushima Current Core Water is, however, scarcely discernible or extremely thin, when it is present, just along the coast in San'in District $(b)$, while it is rather thick in just the coastal zone of Hokuriku District (a). The lower limit of the isohaline $34.2 \%$ which indicates roughly the boundary between the Tsushima Current Core Water and the underlying Japan Sea Central Water is nearly constant at the level of $150 \mathrm{~m}$ just along the coasts in both sections.

conforms exactly to what is mentioned just above. It is also seen that the Superficial Water mass gradually becomes thin toward the northwest region of the sea, where it is confined to the very thin uppermost layer in both sections.

There are two possible factors responsible for the reduction of the thickness of the Superficial Water mass from south to north along the eastern coast of the Japan 
- Sea: one is the extension of the water mass toward the northern offshore area induced by the southeast monsoon and the other is the short reach of the Southeast Superficial Water in the coastal branch of the warm current entering the sea through the eastern channel of the Tsushima Straits (Mryazaki \& Abe 1960), which seemingly never flows north beyond Noto Peninsula, middle Honshu, but makes a turn in the west of the peninsula eventually to flow back as coastal or offshore counter currents). The thickness of the Superficial Water mass off San'in District, 100-130 m as estimated from the distribution of the okaba community I (p. 339 of Part IV), is close to the sill depth $(120 \mathrm{~m})$ of the eastern channel of the Tsushima Straits. As the entire levels of that channel are occupied by the inflowing Southeast Superficial Water during the warm season (MIYAZAKI \& ABE 1960), it seems very probable that the vertical range of the Southeast Superficial Water, and then the living space of the okaba community I, in the southernmost region of the Japan Sea is determined first of all by that sill depth. It is unknown, however, what determines exactly the thickness of the Superficial Water mass in the northwest region of the Japan Sea. The water is very thin there, less than $20-30 \mathrm{~m}$, and demarcated by a sharp thermocline between it and the underlying water. Probably, a number of factors such as the original thickness of the spreading Upper Water and Peripheral NW Pacific Central Water masses (pp. 88-90 of this paper), local drainage and insolation, etc. may be concerned with determing the thickness. In this respect, it seems to be especially important to note that the NW Pacific Surface Water flowing northward through the East China Sea and mixing actively with the surface water of that marginal sea is gradually raised and reduced to only $25-50 \mathrm{~m}$ thick when it enters the Japan Sea through the western channel of the Tsushima Straits (Mryazaki \& Abe 1960).

The extension of the Superficial Water will bring about a marked drop of salinity in the upper layers of the Japan Sea and then this will check the distribution of many of the stenohaline oceanic epipelagic animals and of the inhabitants of the waters neritic but exposed to the open sea, those animals which are of the origin in the Kuroshio waters and are commonly found off or along the Pacific coasts of Japan. Most of these animals seem to avoid the low salinity of the Superficial Water so that they are almost missing from the upper layers of the Japan Sea (Section 3.4 and pp. 376-377 of Part III). On the other hand, as mentioned already (Section 3.5), some mesopelagic animals are met with much more frequently on the Japan Sea side than on the Pacific side of Honshu Island. The typical ones of them are fishes of the families Regalecidae, Trachipteridae and Molidae, which are considered normally to

4) SudA \& HidAKa (1932) have shown that clockwise eddies are developed in summer months in the coastal areas respectively off the eastern San'in District, off Wakasa Bay and west of Noto Peninsula and they induce there inshore counter currents. The existence of an eddy off the eastern San'in District is again confirmed by UdA (1934a, fig. 48) and Sizova (1961). Moreover, UdA (1934a, pp. 156-157) postulates that an anti-clockwise eddy of a large scale is formed northwest of Noto Peninsula possibly due to the coastal topography and it prevents further straight flowing of the surface water toward the northeast. 
inhabit the NW Pacific Central Water and enter the Japan Sea through the Tsushima Stratis in such number as to be caught under a special condition fairly frequently in the inshore waters along the eastern coasts of the sea (Nishimura 1962a, 1962b). The mass invasion of the mesopelagic animals suggests clearly the vigorous influx of the NW Pacific Central Water as a subsurface current under the diluted Superficial Water through the Tsushima Straits. Further, the NW Pacific Central Water is supposed to flow into the sea through the western channel of the Straits and follow in the main the offshore branch of the warm current, as the mesopelagic animals mentioned above are hardly found in the coastal waters during their northward migration in midsummer to autumn. Really, MrYAZAKI \& ABE (1960) analysed the T-S diagram and showed that from June to November the almost pure NW Pacific Central Water flows north through the western channel of the Tsushima Straits under the upper layer of the markedly diluted Northwest Superficial Water, while the eastern channel of the Straits is occupied wholly by moderately diluted Southeast Superficial Water from the surface to the bottom. The mesopelagic animals driven into the Japan Sea by this inflow of the NW Pacific Central Water mass will be largely confined to the offshore central region of the sea (see below) . till late autumn when the turning over of water is initiated by thermal convetion and the animals are brought up to the surface layer to be exposed to the effect of the northwest monsoon (p. 83 of this paper) which will then carry them south to the inshore waters along the eastern coasts of the sea ${ }^{5}$.

In midsummer, the low salinity Superficial Water of the Japan Sea will gradually shift northeastward in accordance with the general directions of the warm current and the prevailing wind, and a considerable part of.it will flow out to the Pacific throught the Tsugaru Straits between Honshu and Hokkaido Islands and spread over an extensive area south of Hokkaido and the Southern Chishima Islands (Lesser Kuriles), where the warm-water neritic pelagic communities become much prominent in summer to autumn, especially from September to October (p. 88 of Part II). The occurrences of shoals of the neritic teleost Engraulis japonica and its spawning hundreds of miles off the coasts of southeastern Hokkaido and Sanriku District (Pacific side of northeast Honshu) in summer months (NAKar et al. 1955; Odate 1957) and also the predominating distribution of the neritic chaetognath Sagitta bedoti in the same area during the same season (Tokioka 1957, 1959) seem largely to owe to the flowing out and wide spreading of the Supcrficial Water of the Japan Sea.

As mentioned already, the volume transport of the warm current through the Tsushima Straits attains its peak in September; then, the warm current in the Japan Sea proper is estimated to become strongest in the period from September to October.

5) On the Pacific side of Japan, the northwest monsoon and the induced drift currents will carry the pelagic animal populations toward the oceanic central area; thus, there will be much less opportunity for those populations to approach and be caught in the inshore waters there. 

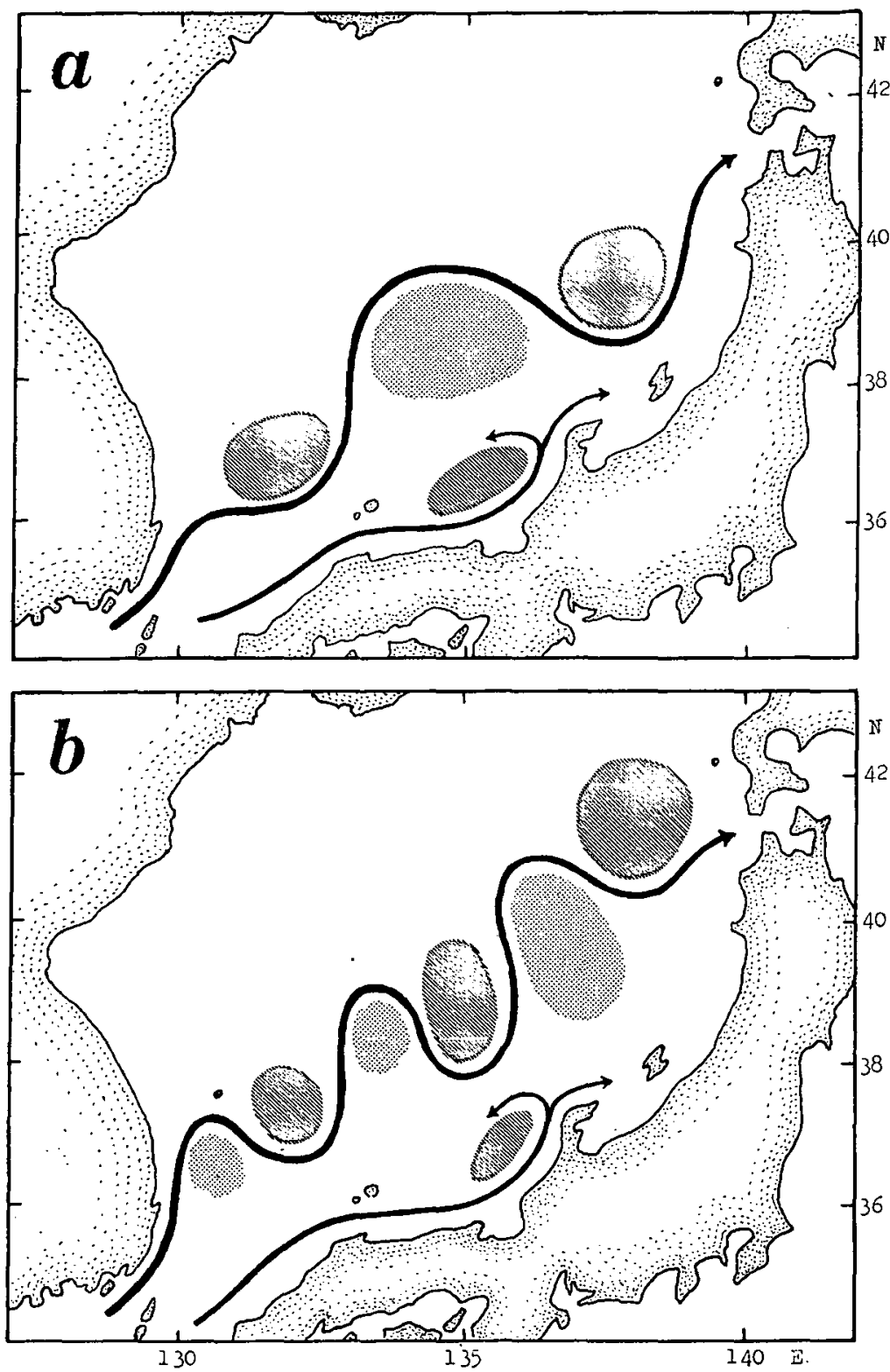

Fig. 42. Schematic representation of the development of eddy areas along the stream belts of the Tsushima current in summer. a-August, 1949; $b$-September, 1948.

The hatched are the cold-water areas representing cyclonic eddies, and the dotted are the warm-water areas representing anticyclonic eddies. 
This period corresponds to the season of the monsoon change, when no significant wind nor any prominent wind-induced surface current prevails in the Japan Sea. The stream belts of the warm current, especially the offshore one, will then begin, being free from the stress of any uniform drift currents, to meander on account of the increased lateral shear imposed by higher velocity. The development of meandering will bring about several cyclonic and anticyclonic $\epsilon$ ddies of large scales along either sides of the stream belts of the warm current. The formation of several cold-water and warm-water areas along the main streams of the warm Tsushima current, invariably observed clearly in late summer to autumn (Fig. 42), is supposedly due to such eddies.

It seems that these eddy areas will trap the pelagic animal populations that have been carried northward by the offshore branch of the warm current and retain them within till late autumn when the northwest monsoon begins to prevail and releases the populations from those areas to be drifted southward. In this way, the further northward migration of the bulk of tropical-subtropical oceanic animals beyond $39^{\circ}$ or $40^{\circ} \mathrm{N}$. Lat. in the main region of the Japan Sea is checked (p. 88 of Part II), and appearances of those animals in the inshore waters of the sea are concentrated to the coasts from middle Honshu to northwest Kyushu (Sections 3.2 \& 3.5).

The Tsushima Current Core Water, accordingly the living space of the okaba community II, is sandwiched between the Superficial Water above and the Japan Sea Central Water below. The upper limit of the Japan Sea Central Water seems to be kept almost at the same level (ca. $150 \mathrm{~m}$ ) along the whole west coast of Honshu as inferred from the vertical range of the okaba community IV inhabiting this water mass (p. 339 of Part IV), while the Superficial Water is reduced to nearly half in thickness from south to north along the same west coast (see above, pp. 94-96). Consequently, it seems that the coastal branch of the Tsushima Current Core Water becomes somewhat thicker in the region off middle to north Honshu than in the region off San'in District in west Honshu; and this is actually proved by physical oceanographic data (Fig. 41). The phenomenon is supposed to be brought about by the coastwise swing of the offshore branch of the warm current and the confluence of the offshore and coastal branches in the region off northern Honshu: unless the velocity of the joined currents is markedly increased, the layer of the Tsushima Current Core Water must become thicker there to hold the water of the two branches. The bottom of the Tsushima Current Core Water which is maintained throughout the southeastern region of the Japan Sea at ca. $150 \mathrm{~m}$ is considered to be determined firstly by the sill depth $(140 \mathrm{~m})$ of the western channel of the Tsushima Straits through which the water in question penetrates into the sea as the lower part of the warm current and flows northeastward filling the space above the Japan Sea Central Water mass in the southeastern region of the sea.

\subsubsection{Autumnal Aspects}

When the southeastern region of, the Japan Sea is still under the strongest 
influence of the warm Tsushima current in September to October, the northwestern region is alrealy covered by the Siberian continental air mass and then influenced by the developing northwest monsoon with the extension of the atmospheric polar front from the continent to the central or southeastern region of the Japan Sea (ARAKawa 1948). Thus, weak south to southwest drift currents are induced in the northwestern region of the sea and this seems to be responsible for the early initiation of the southward migration of animal populations of groups $I$ and $I I$ which have been maintained in that region, especially in the inshore waters of Maritime Province, during the summer (Fig. 23, Ib \& IIb, of Part II).

At the same time, the thermal convection is started in the entire region of the Japan Sea by surface chilling; this leads to the gradual disappearance of the low salinity Superficial Water masses and in its turn brings up in the northwestern region of the sea the Lower Water and in the southeastern region the Upper Water respectively to the sea surface (p. 70 of this paper). Under such circumstances, the vigorously streaming offshore branch of the warm Tsushima current seemingly emerges on the sea surface forming there a very distinct Front against the colder water mass, and then the weak drift currents induced in the northwestern region of the sea will be checked by this Front and in all probability turn west- or southwestward along the Front. The pelagic populations being carried by the drift currents mentioned above will inevitably move along the Front and ultimately approach to the southeastern corner of Korean Peninsula or further to the coast of the westernmost district of Honshu, but never enter straightly the warm water region of the sea and approach to the coasts of middle to north Honshu. This is just the pattern of southward migration of the animals of groups $I$ ard $I I$ discussed in Section 3.8. Recently, Kasahara \& Ito (1968) noted that the shoals of the common squid Todarodes pacificus found in the waters north of the Polar Front in late summer to autumn never mingled with those in the waters south of the Front and that the former were seemingly migrating southwestward to the southeast coast of Korea, quite independently of the latter.

Until November to December when the northwest monsoon grows considerably and the influx of the warm Tsushima current drops steeply, the southward drift currents, though fairly developed, will in all likelihood not break through the Front of the warm water mass to carry their pelagic populations south. Thus, the appearances of the surface-living animals of the northern continental origin such as the pink salmon, young Atka mackerel, several species of whales, seals and fur seal in the warm water region of the Japan Sea are seen first in middle or late winter after the tropical-subtropical pelagic populations hitherto predominated there have wholly moved south and sunk down (Section 3.6; see also Fig. 37). Further late, in January to March, the boreal bathypelagic zooplankters will breed in the central region of the sea and subsequently their larval populations will appear in shallow layers to be drifted south in significant abundance (pp. 81-83 of Part II). 


\subsubsection{Returning to the Winter Aspects}

With the progress of cold season, the convection becomes stronger and stronger in the entire Japan Sea. The vertical mixing with the subsurface haline water and the evaporation greatly accelerated by the cold and dry northwest monsoon increase rapidly the surface salinity, and then the neritic animal populations hitherto predominated so prominently in surface layers over the wide area of the sea (p. 93 of this paper) will gradually disappear. In succession, the subtropical midwater animals are brought up to and widely dispersed in the surface layer (p. 89 of Part II). The subtropical midwater populations that entered the Japan Sea at the peak of the warm water inflow in September to October will reach the northern region of the sea in two or three months, and will appear in surface layers in a greater part of the eastern and northeastern region of the Japan Sea with the decline of the Superficial Water and predominate there during the period from late October till January, showing the most diverse subtropical color though the water temperature is approaching to the annual minimum.

Along the west coast of Honshu, the water is chilled and the salinity is raised in December to January to the levels respectively just intermediate between the Tsushima Current Core Water and the Japan Sea Central Water in temperature and only slightly less than the Japan Sea Central Water in salinity, i.e. $12-14^{\circ} \mathrm{C}$ and $33.9-34.1 \% \mathrm{~S}$. Since this condition is brought about chiefly by thermohaline convection, it is maintained throughout the whole strata above the continental shelf along the west coast of Honshu, but possibly except for the area off the west part of San'in District which is seemingly still under the influence of the warm Tsushima current. It is during this period that the members of the okaba community III, adapted to the water of such conditions as mentioned above, come near the inshore zone from their summer habitats in moderate depths and frequently even venture into quite shallow places (pp. 377-378 of Part III). As a rule, the water of the region will further be chilled and concentrated of salinity eventually to be transformed into the Upper Water of the winter season. After this stage, the majority of the animals of the abovementioned transient or peripheral water mass become apparently scarce over the greater part of the shelf, possibly due to the concentration in certain limited areas of special hydrographic condition during the period from late winter to spring. This phenomenon is especially well known as to the migratory neritic members such as the chub mackerel Pneumatophorus japonicus. During the coldest season from February to April, dense populations of the adult chub mackerel are frequently found in certain narrow areas in the region from Toyama Bay to Sado Island in the eastern Japan Sea, close to the sea floor around $100 \mathrm{~m}$ deep (Nishrmura \& OKachi 1957). They hardly hover around far away from the sites; no doubt they are wintering there. Similar areas are also found in the shelf zone of San'in District in west Honshu, for instance in Wakasa Bay, off Sakai and Hamada. All these areas are more or less stationary, and according to Machinaka (1960), they correspond to the warm-water areas 
formed by local anticyclonic eddies observed not infrequently along the west coast of Honshu in early winter (Fig. 43). It seems that such warm-water areas formed at different localities and in various scales are the wintering quarters for many animals of the upper peripheral water of the Upper Water mass, i.e. the okaba community III and the corresponding temperate neritic community, and presumably also for the animals of the Tsushima Current Core Water (=the NW Pacific Central Water), i.e. the okaba community II and the corresponding subtropical pelagic community, in the southeastern region of the Japan Sea. However, for the communities of the Superficial Water mass, i.e. the okaba community I and the corresponding tropical-subtropical pelagic community, no such wintering site seems

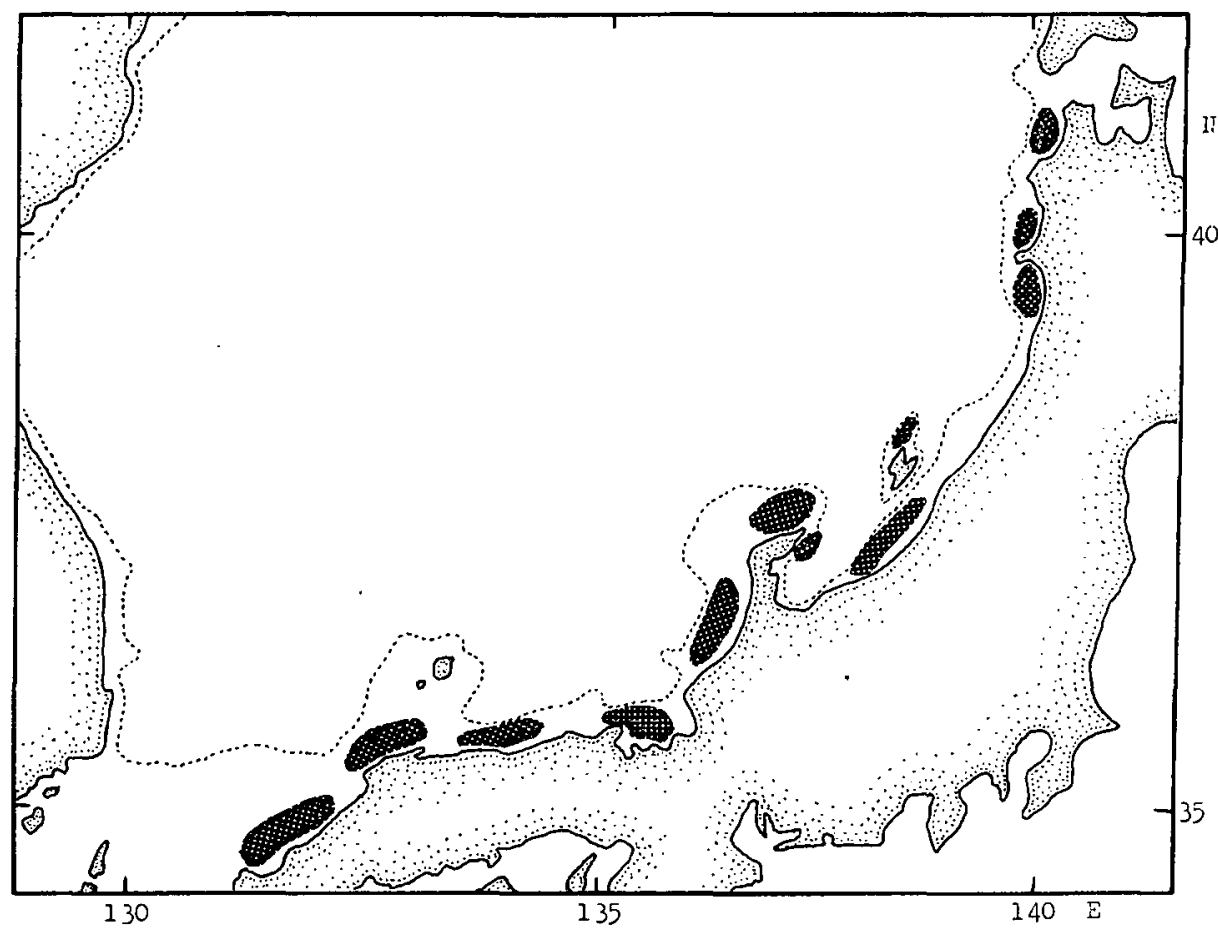

Fig. 43. Distribution of coastal warm-water areas formed by local anticyclonic eddies in late autumn to winter. (Slightly modified from Machinaka 1960).

to be available within the Japan Sea. This, together with other unfavorable conditions, checks the members of these genuinely warm-water communities from being the permanent members of the biotic elements of this marginal sea as will be discussed in detail later (Section 5.3).

In the southeastern region of the Japan Sea, the winter convection reaches the maximum level of 150-200 $\mathrm{m}$ in March, forming there a distinctive thermocline which sharply separates the upper homogeneous layer of higher water temperature 
from the lower colder layer; and prominently enough the bottom level of the upper layer is maintained, broadly speaking, at about the same depth throughout the greater part of the area referred to, though somewhat variable in certain areas according to the temperature and salinity conditions just prior to the start of the convection. The lower limit of vertical range of this upper homogeneous water mass, namely the Upper Water, will then be sustained almost throughout the remaining period of the year. Conforming to this, the lower limit of vertical distribution of the warm-water communities, i.e. tropical to temperate pelagic communities and all of the okaba bottom communities, in the southeastern region of the Japan Sea can be said ultimately to be determined by the winter thermohaline convection. On the other hand, in the northwestern region of the sea the winter convection

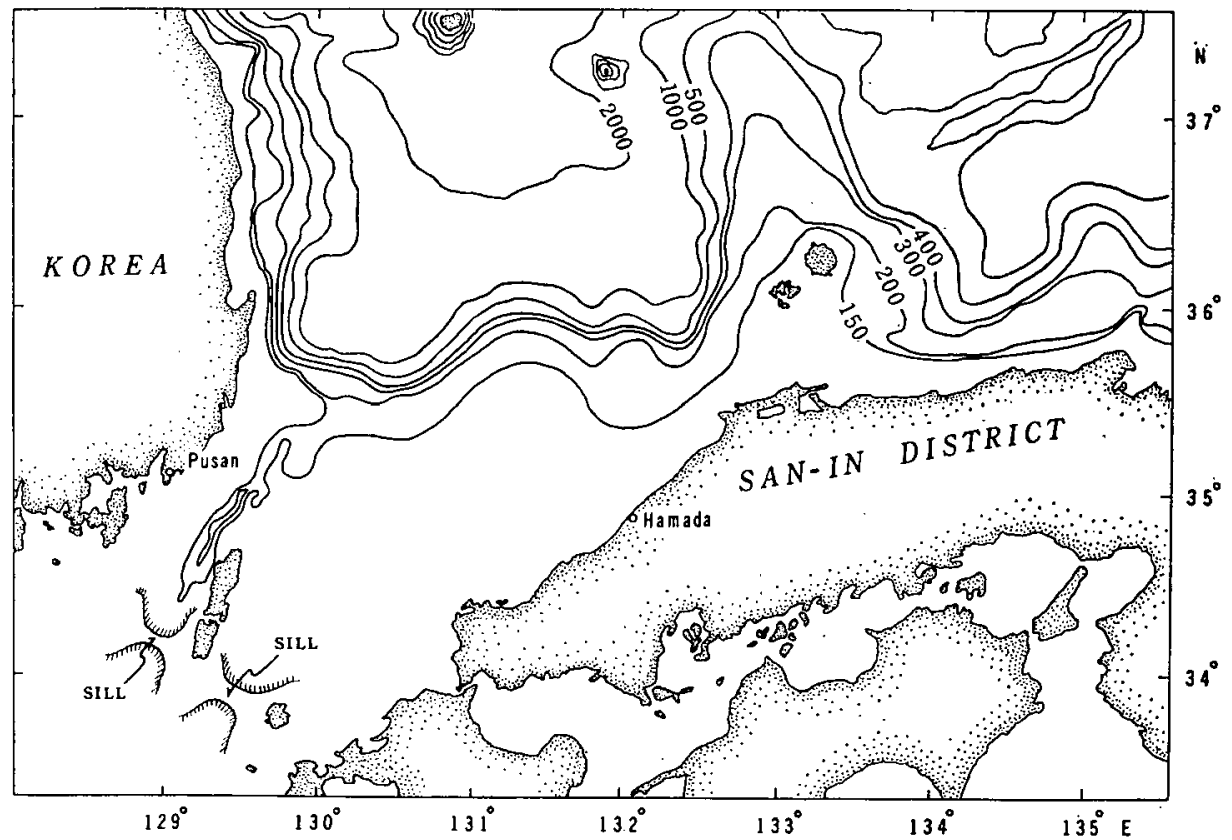

Fig. 44. Bathymetric chart of the southernmost region of the Japan Sea.

grows more than 2000-3000 $\mathrm{m}$ down to the deep sea floor, and in the central region it reaches the level of ca. 250-300 m (RADzikhovskaya 1961).

The vast space under the Upper Water mass of the Japan Sea is occupied by the Lower Water masses, sustaining the arctic to subarctic or boreal communities, i.e. deep-water pelagic communities and all of the taraba bottom communities. As mentioned in Section 3.1, the southward distributions of a large part of northern cold-water animals are limited off Hamada and its vicinity in the western region of San'in District on the Japanese side of the sea, while nowhere on the continental side opposite to the afore-mentioned region the northern cold-water elements decrease so 
markedly and sharply as on the Japanese side, a considerable number of them being found off the southern coast of Korean Peninsula or even further south off the Chinese coast (p. 51 of Part I). As seen in Fig. 44 showing the bathymetric chart of the southern region of the Japan Sea, the continental shelf is very narrow along the east coast of Korea and the north coast of San'in District east of Hamada, but it is widened much west of Hamada as the $150 \mathrm{~m}$ bathymetric line indicating the shelf edge sharply extends offshore there. This bottom topography seems to be responsible for the situation that the northern cold-water populations inhabiting the layers deeper than 150-200 $\mathrm{m}$ approach easily to the coasts of both eastern Korea and eastern San'in District, but they are kept far to the coasts of western San'in District and northwestern Kyushu; in the result, the animals of those communities are caught quite commonly by coastal fishermen in the former region but not in the latter. Morever, as mentioned already (pp. 74-75 of this paper), the Peripheral NW Pacific Central Water, much warmer and more haline than the Lower Water, occupies the whole space above the wide shelf zone off the western San'in District during winter months and blocks any approach of the cold-water populations to the coast in that season.

Fig. 44 also shows that a narrow trough is cut from the deep basin of the Japan Sea to the northern slope of the sill in the western channel of the Tsushima Straits. As it is more than $200 \mathrm{~m}$ deep at the maximum, it seems quite likely that a part of the Lower Water which dashes, if any, into the trough will pass over the sill and flow along the southern coast of Korea to the deeper basin of the East China Sea. Such a flood of the Lower Water is seemingly not infrequent in the winter season when the surface water of the northwestern region of the sea is driven by the monsoon southwestward to be piled along the east coast of Korea and the pressure gradient induced in this way generates in turn a powerful gradient current directed to the south. The deeper part of this gradient current may hit against the continental slope off the western San'in District and be deflected, and at least a part of the deflected flow may dash into the above-mentioned trough ${ }^{6}$. Then, some populations of the Lower Water masses can

6) The shallower part of the gradient current, on the other hand, meets the Peripheral NW Pacific Central Water inflowing into the Japan Sea through the western channel of the Tsushima Straits and makes, together with the monsoon wind, the latter change its course from northeast to east and finally to southeast. This circulation pattern of shallow water conforms to some extent to the result of the drift bottle experiments; according to UDA (1950), for instance, the bottles released within 100 nautical miles off the east coast of Korea in winter are rapidly drifted to the coast of San'in District, being mostly concentrated in the eastern province of Shimane Prefecture. Thus, it is considered that the Peripheral NW Pacific Central Water is deflected off this province and then approach to the coast of San'in District. This water will subsequently flow westward along the coast of the district and eventually to the sea northwest of Kyushu, as it is already pointed out by SuDA (1938) and MIYAZaKi (1952) that a southward flow is observed in the eastern channel of the Tsushima Straits during winter months. Such a flow pattern is supposed to be responsible for the facts that the Peripheral NW Pacific Central Water is limited in its extension only to the area off the western San'in District in the Japan Sea, never flowing further northward (Fig. 31 of this paper), and that the majorities of the temperate and subtropical migratory animals of groups $I$ and $I I$ that have moved south along the east coast of Korea or in the western half of the Japan Sea in their autumnal migration pass through (the eastern channel of) the Tsushima Straits to the northwest waters of Kyushu for wintering (Fig. 23, Ib \& IIb, of Part II), possibly availing the southward flow in the straits referred to above. 
invade the East China Sea along the southern coast of Korea and through the Yellow Sea.

\section{Characteristics in Biological Production in the Japan Sea}

\subsection{Characteristics in Plankton Production}

It is pointed out by Heinrich $(1961,1962)$ that the plankton production in the main region of the Japan Sea is unbalanced, as the phytoplankton production is disproportionately greater than zooplankton prcduction during the spring vegetative period and a large part of phytoplankton will die out without being consumed by herbivorous zooplankters; thus, the phytoplankton biomass fluctuates greatly with seasons quite independently of the zooplankton biomass. In fact, the phytoplankton biomass in the central and southeast regions of the Japan Sea is many times larger in the period from February to March or April than that in the remaining period of the year. And it is very noteworthy that the greater part of the spring biomass is occupied by a single diatom species Coscinodiscus wailesii. Just after the spring bloom, i.e. April to May, a large quantity of partially disintegrated Coscinodiscus is frequently hauled from deeper layers (p. 84 of Part II). This slimy and stinking mass occasionally comes into the inshore waters and will destroy fishes and invertebrates and do serious economical damages to local fisheries (ANON. 1965).

The main herbivorous copepods in the Japan Sea during the season under consideration are Calanus plumchrus and to a lesser degree $C$. cristatus, the same species as found in the oceanic region of the Bering Sea where the plankton production is said to be well balanced (HEINRICH op. cit.). As to the difference in plankton production between the Japan Sea and the Bering Sea, Heinrich refers merely to the earlier start of the phytoplankton bloom in the Japan Sea. It is, however, the question of essential importance to clear why the phytoplankton bloom is started so early in the Japan Sea.

In the first place, the quality of the phytoplankters involved in the bloom seems to be important. As mentioned already (p. 84 of Part II), most of the phytoplankters in question are subtropical or tropical oceanic species; this is quite different from the constitution of the vernal bloom in the more northerly waters of the Japan Sea or in the Okhotsk and Bering Seas, which is predominantly of the arctic or subarctic nature. The tropical-subtropical phytoplankters seemingly start to bloom in January or February, i.e. considerably before the water temperature drops to the annual minimum, being stimulated by the enrichment of the surface water due to the winter convection, the gradual increase of daylight and the prolongation of daytime. The breeding of Calanus plumchrus is estimated, on the other hand, to take place in the central and southeastern regions of the Japan Sea in the period from January to March (p. 83 of Part II), a little later than in C. cristatus and nearly synchronized with the start of phytoplankton bloom. Since the consumption of phytoplankton by the 
nauplii and early copepodites of such copepods is very probably insignificant, the phytoplankton bloom will attain a very high population density in February to March without being affected much by grazing; perhaps it is the middle of March or later that the grazing by the copepods, having now attained late copepodite stages, becomes significant to any degree. It should also be noted that the predominance of Coscinodiscus wailesii in the bloom in this area is very suggestive that its size might be too large to be grazed by nauplii and early copepodites of Calanus plumchrus and most of the other herbivorous larval zooplankters thriving in that season.

In the second place, the environmental situation under which the phytoplankton growth takes place is important. As ingeniously shown by SVERdRuP (1953), for effective production of phytoplankton the thickness of the upper mixed layer of the sea must not exceed the "critical depth", i.e. the depth above which the total photosynthesis is equivalent to the total respiration per unit of surface. Once, Еломото (1959) calculated the value of the critical depth in the area west of Kyushu extending approximately from $32^{\circ}$ to $34^{\circ} \mathrm{N}$. Lat. and found that in the area under consideration the upper mixcd laycr was almost equal to or hardly exceeded the critical depth even in midwinter when the radiation energy was smallest and the upper mixed layer reached the deepest level, concluding that the period when the photosynthesis was smaller than the respiration might be very short or absent at all in that area. In the central and southeastern regions of the Japan Sea extending roughly from $35^{\circ}$ to $40^{\circ}$ N. Lat., the upper mixed layer attains its maximum thickness of 150-200 m (p. 102 of this paper), while the critical depth, though regrettably no sufficient datum is available for its calculation, may be in all probability nearly equal to or slightly smaller than the value calculated for the area west of Kyushu?, namely ca. 100$200 \mathrm{~m}$ at the minimum (ENomoto op. cit.). Thus, in the central and southeastern regions of the Japan Sea, the environmental situation in winter months might at first sight appear to be unfavorable for the effective production of phytoplankton, a conclusion rather unfit for the observed fact. It seems, however, very important to pay an attention to the point that the extreme value of the thickness of the upper mixed layer and that of the critical depth may not be coincident but be separated from each other with an interval of about two months, i.e. the maximum of the former may be attained in March, while the minimum of the latter in December to January. It is highly likely that the thickness of the upper mixed layer hardly exceeds the critical depth at any moment throughout the winter months as shown in Fig. $45 a$, even though the maximum of the former per se does exceed the minimum of the latter per se. Thus, the phytoplankton growth is possible there quite early in winter from January to March, when the surface water is already adequately enriched and the light condition has turned favorable.

7) The transparency of water and the weather conditions are much similar between the two areas but the mean latitude is somewhat higher, and therefore the incident radiation is somewhat smaller, in the Japan Sea than in the Kyushu waters. 
The phytoplankton bloom under consideration has been generally described as "vernal bloom" (Section 3.7, etc.), and this is correct from the point of the season concerned. The nature of the bloom is, however, evidently of the "autumnal bloom", because the bloom occurs before the period of the annual minimum water temperature and consists largely of subtropical species but not of the arctic to north-boreal species which constitute the vernal bloom in the more northerly waters. In fact, the vegeta-

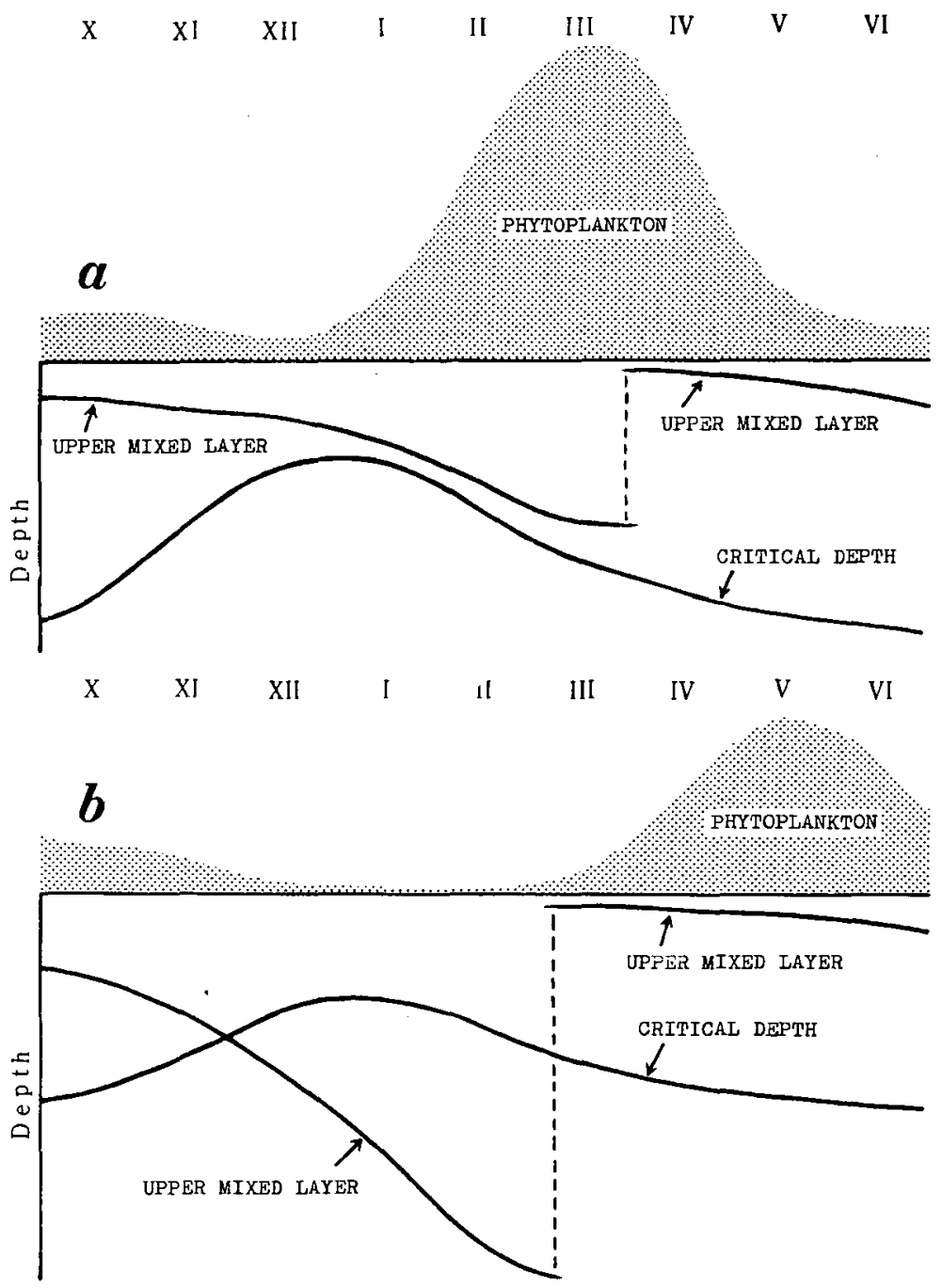

Fig. 45. Diagrammatic representation of the seasonal change of phytoplankton standing crop in the central-southeastern (a) and northwestern (b) regions of the Japan Sea, in a supposed relationship to the thickness of the upper mixed layer and the critical depth.

Roman numerals above in each figure indicate months. For further explanation, see the text. 
tion of subtropical phytoplankters under consideration just follows the "biological summer", the period from late October to January or February when tropical populations are most flourishing in the main region of the Japan Sea (p. 89 of Part II).

The unbalanced plankton production mentioned above is not applicable to the neritic waters along the west coast of Honshu Island, where zooplankters consisting of various kinds of warm oceanic microcopepods, the temperate Metridia pacifica, the boreal Pseudocalanus elongatus and Oithona similis, the amphipod Parathemisto japonica, the euphausiid Euphausia pacifica, etc. are maintained considerably in the period from January to middle March prior to the mass appearance of the bathypelagic zooplankton (p. 90 of Part II), and all these zooplankters seemingly graze the phytoplankton to such a degree as to check the growth beyond the balanced level. In the central region of the Japan Sea, on the other hand, zooplankters are very scarce and no dominant species are found in the early phase of the phytoplankton bloom (MEshcheRYAKOVA 1960). After their mass drift to the neritic waters along the west coast of Honshu (pp. 81-83 of Part II), the bathypelagic zooplankters mentioned above, now advanced to the late larval stages, will actively graze the phytoplankton found there. It is true that Coscinodiscus wailesii is much less in the southeastern neritic region than in the central region of the sea at the peak of its bloom from March to April (Meshcheryakova op. cit. and my own observations in 1957 and other years).

The other area of the balanced plankton production is seen in the north of the Polar Front. As seen in Fig. 16 of Part II, the vegetation of the subtropical phytoplankton is limited to the central and southeastern regions of the Japan Sea south of the Polar Front. Meanwhile, in the northern and northwestern regions, the true "vernal bloom" consisting of arctic to north-boreal phytoplankters takes place much later, from April to May, after the period of the annual minimum water temperature (pp. 84-86 of Part II). And because of the late start of the bloom, the plankton production is seemingly balanced in those northerly waters as in the oceanic region of the Bering Sea (Heinrich 1961, 1962). In the neritic area off the southern Maritime Province, for instance, it is known that the phytoplankton is very poor from December through February and includes only the so-called knephoplankton composed of Halosphaera viridis and the diatoms of the genera Coscinodiscus and Denticula, and that the increase of phytoplankton biomass and the change of plankton components to the chaeto- and sira-planktons consisting of Chaetoceros debilis, $C$. atlanticus, $C$. subsecundus, Corethron hystrix, Thalassiosira nordenskioeldii, etc. start in the middle of March and the biomass attains the peak in April to May (Gail 1936). MeshaheRYAKova (1960) also states that the phytoplankton biomass is never increased till middle April in the northwestern offshore waters of the Japan Sea. It is supposed that in these regions the winter thickness of the upper mixed layer is very large, attaining $2000-3000 \mathrm{~m}$ at the maximum (p. 103 of this paper), and exceeds by far the critical depth, though the latter is seemingly somewhat greater there than in the central and southeastern regions of the sea in spite of the higher latitudes 
$\left(38^{\circ}-50^{\circ}\right.$ N. Lat.), because much a greater water transparency (NISHIDA 1955) and much a finer weather (KAWASAKr 1956) prevail throughout the winter months; thus, there is no possibility of the phytoplankton growth to take place in this season. It will not be until the middle of March or so that any stratification is formed at a level much shallower than the critical depth on account of the thawing sea ice and permits the phytoplankton to propagate and accumulate in the upper mixed layer (Fig. 45b). The growth of phytoplankters will then be much accelerated by the marked intensification of stratification from April to May due to the development of the surface water of higher temperature and lower salinity (p. 94 of this paper). According to Nakai (1942b) and Meshaheryakova (1960), the population of the most important herbivorous zooplankter Calanus plumchrus in the northwestern region of the Japan Sea attains its full thriving in May to June in a fairly well co-ordination with the vegetative cycle of phytoplankton, and thus the plankton pruduction is supposed to be rather well balanced there.

However, there is seemingly an exception in the region north of the Polar Front. According to GAIL (1936), the above-mentioned vernal bloom consisting of chaeto- and sira-planktons in the northwestern Japan Sea is most prominent in a thin superficial layer in the narrow coastal zone. The oceanic species Calanus plumchrus which may consume intensively the blooming phytoplantkon is not found in that narrow coastal zone during the period in consideration. Instead of C. plumchrus, the adult population of Calanus glacialis that has survived the winter there will graze the phytoplankton, but the population seems in all likelihood too small to affect the bloom significantly. Thus, the plankton production in the narrow coastal zone is inevitably unbalanced (HeINRICH 1961, 1962). It is needless, however, to mention that the vernal bloom has a decisive influence on the successful outburst of young populations of $C$. glacialis characteristic to the northwestern coastal zone of the sea during the season from late summer to autumn (KUN 1949; and p. 87 of Part II).

In the region off the west coast of Hokkaido, the situation is intermediate between the central-southeastern and northwestern regions. There, a phytoplankton propagation dominated by subtropical species takes place from winter through early spring when the region is in the period of the annual minimum water temperature; this is then succeeded by the vernal bloom consisting of Chaetoceros-dominant arcticnorth boreal phytoplankton (foot-note 4 on p. 86 of Part II). The phytoplankton biomass is thus maintained at high levels for a much longer period. A similar situation may hold for the southwestern region of the Japan Sea off the east coast of Korea; Meshcheryakova (1960) states that the vegetation period of phytoplankton is much prolonged there. In these regions, the plankton production may be moderately balanced.

To sum up, the central-southeastern region of the Japan Sea in general is characterized by an earlier start of the phytoplankton propagation which is qualitatively the "autumnal bloom" and not followed by any prominent "vernal bloom", hence by 
the unbalanced plankton production, although the production is somewhat balanced in the neritic zone where some herbivorous zooplankters thrive in the early phase of the bloom prior to the mass appearances of Calanus plumchrus and other large-sized bathypelagic herbivores. In the northern-northwestern region, on the other hand, a well balanced production is generally maintained beacuse of the later start of the "vernal bloom," although the production is somewhat unbalanced in the neritic zone where no large populations of any bathypelagic herbivorous zooplankters are found. In the intermediate region between the above-mentioned two, the production is somewhat unbalanced in the earlier ("autumnal") phase but balanced in the later ("vernal") phase of the bloom and as a whole seemingly moderately balanced.

The appearance of only the "autumnal bloom" consisting of subtropical phytoplankters and never followed by the "vernal bloom" consisting of arctic-north boreal species in the central-southeastern region of the Japan Sea is due first to the climatic condition of this region that the area, situated south of the Polar Front and occupied by the warm Upper Water mass, is still affected by a subtropical or warmtemperatue climate even in midwinter. Under such a condition, the subtropical phytoplankters will be able to propageate if some nutrients are supplied, while the growth of arctic-north boreal phytoplankters will naturally be suppressed. It is also possible that the remarkable propagation of the subtropical phytoplankton depletes almost completely the nutrients necessary for the growth of arctic to north boreal phytoplankters, which would otherwise be expected to follow it.

\subsection{Biological Seasons and Bioclimatic Regions}

As stated above (pp. 107-108), the biological summer in the central and southeastern regions of the Japan Sea is considered to continue till January and then succeedid by the biological autumn characterized by the prominent "autumnal bloom" for the period from February to March. There, the biological winter is hardly recognizable, because the "autumnal bloom" of subtropical phytoplankton is succeeded immediately by the mass appearance and rapid growth of the larval bathypelagic zooplankton which are said in the more northerly waters like the Bering Sea to follow the "vernal bloom" of arctic-north boreal phytoplankton and can be taken as an indicator of the biological spring, without any definite interval which might be treated as the biological winter characterized among others by the total absence of phytoplankton vegetation (HeINRICH 1959). It is suspected that the biological winter is entirely lacking within the shallow layers of the Japan Sea south of the Polar Front which are occupied by the Upper Water throughout winter months, and that the abovementioned mass appearance of the larval bathypelagic zooplankton there is a result of "diffusion" of the biological winter phenomena occurring in the more northerly waters or dieper layers of the sea. HeinRich (op. cit.) reckons the reproductions of Calanus plumchrus and $C$. cristatus as other characteristic phenomena of the biological winter; and in fact, the reproductions of these copepods take place limitedly to 
deep layers only in this marginal sea, at least in its southeastern region (pp. 82-83 of Part II). Thus, the biological seasons deviate greatly from the meteorological seasons; and based on the information given just above and in Section 3.7, the biological calendar in this area is suggestd as: SUMMER (August to January)-AUTUMN (February to March)-SPRING (April to July).

The hydrological calendar, on the other hand, may be presumed for this area as: SUMMER (July to October)-AUTUMN \& WINTER (November to March)$S P R I N G$ (April to June). For such a hydrological calendar shown here, the seasonal variations of the warm current and the thermal stratification in the regions are directly responsible. It seems moreover that the autumn and winter in the hydrological calendar cannot distinctly be separated from but are rather continuously merged in each other. As a rule, the biological seasons go after the hydrological seasons: the biological summer starts a month later and ends three months later; therefore, the biological autumn begins three months later and is much shortened; the winter state is eliminated and the spring lasts a month longer.

The meteorological seasons are generally conceived as follows for the Japanese and its adjacent areas (Arakawa 1948; TAKahashi 1951; etc.): SUMMER (June to August)-AUTUMN (September to October) - WINTER (November to March)SPRING (April to May). It is thus evident that a similar relationship exists between the meteorological seasons and the hydrological seasons to that between the latter and the biological seasons, except that the meteorological winter is very conspicuous and lasts for much a longer period. As compared with the meteorological seasons, the biological summer in the central and southeastern Japan Sea south of the Polar Front is much delayed and much prolonged, the autumn is much delayed but lasts for nearly the same span, the winter is inconspicuous or rather hardly discernible, and the spring begins at the same time but lasts much longer.

No doubt such a difference between the biological and meteorological seasons is due to the prevailing of the warm Tsushima current in the central and southeastern regions of the Japan Sea and its physical natures such as: (1) the peak of the influx is attained about a month later than the annual maximum of the atmospheric temperature (Fig. 39); (2) it takes about a month or more for the surface and core water masses of the warm current carrying tropical-subtropical populations to spread widely over the central and southeastern regions of the sea; (3) on account of a large heat capacity, the warm water masses sustain the high temperature condition of the regions for a period long enough to make warm-water populations thrive continuously and survive the meteorological winter. All these are integrated to bring about the abovementioned time lag and difference in duration.

Meanwhile, the fact that the biological, hydrological and meteorological springs start almost synchronously seems to show that the rise of the surface temperature and the northwestward spread of the Upper Water (pp. 88-89 of this paper) are brought about directly by the meteorological factors in situ, namely, the increase of local insola- 
tion and the receding of the northwest monsoon, but not by any extraneous factors working indirectly with a certain time lag.

In the northwestern region off the continent, on the other hand, any significant differences are hardly seen between the biological, hydrological and meteorological

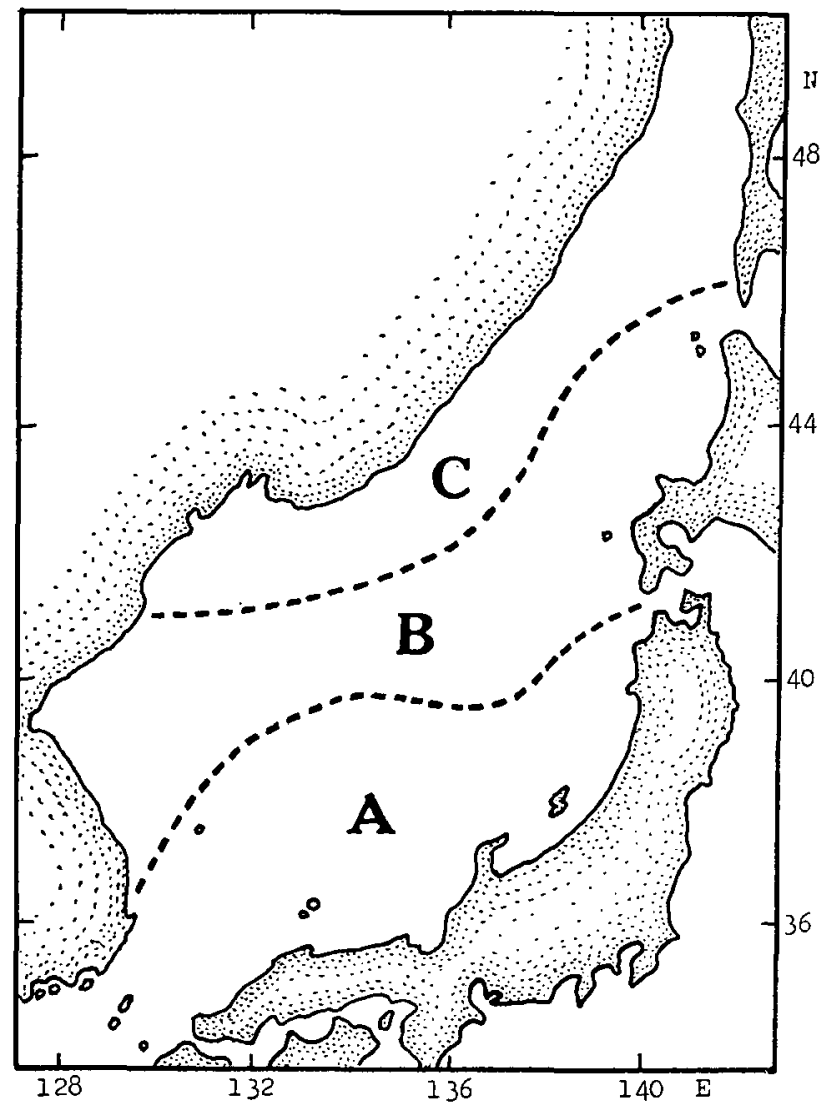

Fig. 46. Bioclimatic division of the Japan Sea.

A-Subtropic Region, where the biological seasons go after the meteorological seasons with a prominent time lag, no biological winter recognized and the plankton production is generally unbalanced; B-Subarctic Region, where the biological seasons with a moderate time lag and the plankton production moderately balanced; C-Arctic Region, where the biological seasons conform to the meteorological seasons and the plankton production is generally balanced.

seasons; for example, Meshaheryakova (1960, pp. 138-139) defined the biological seasons in the northerly waters as: SUMMER (late May or early June to August)AUTUMN (September to early November)-WINTER (late November to March or early April)-SPRING (late March or late April to May). This conformity is 
evidently due to the absence of any powerful influx of water bringing plus or minus energy into this region, where the hydrological and biological processes are then primarily governed by the meteorological factors in situ.

As to the intermediate region between the southeastern and northwestern regions of the Japan Sea, the biological calendar may very likely be of an intermediate character between those of the latter two regions, as expected from the discussions made already in the preceding section.

As a conclusion of this section, Fig. 46 is presented to show the division of the Japan Sea into three regions from the view-points of the biological seasons and the plankton production. Evidently, these regions conform completely to the winter distribution of principal water masses in the sea (Fig. 36a); Region A corresponds to the region of the Upper Water, Region $B$ to the region of the Southern Lower Water, and Region $C$ to the region of the Northern Lower Water. In view of their climatological aspects, these regions may be called respectively the Subtropic, Subarctic and Arctic Regions following the terminology of Tully $(1964)^{8}$ ).

\subsection{Fate of Immigrant Southern and Northern Populations}

As shown already (Fig. 39), the warm Tsushima current flows vigorously into the Japan Sea during the summer season, particularly from August to October. Together with the superficial water of this warm current are transported many tropical and subtropical organisms into this marginal sea. They are either larvae and adults of pelagic animals or pelagic larvae of some demersal animals mainly thriving in the southern East China Sea and the Philippine Sea. During the trip through the central and northeastern regions of the East China Sea, these animals have to be affected more or less by the lowering of salinity in the ambient water, especially strongly in the western area receiving a large amount of river water from the continent. Thus, the animals intolerable to any degree of salinity lowering will fall before they reach the Japan Sea (cf. Section 3.4), while those which are tolerable to moderate salinity drop can enter the sea only through the eastern channel of the Tsushima Straits which is washed by moderately diluted water throughout the depths (MIYAzAKI \& ABE 1960), and those which are tolerable to a considerable degree of dilution enter the sea through both the western and eastern channels of the straits, and especially those passed through the western channel can be transported by the offshore branch of the warm current to considerably high latitudes in the Japan Sea.

These animals carried into the Japan Sea can grow and even propagate there during the warm season of the year, if the life span is short as in many tropical plankton animals. The pelagic larvae of demersal animals may be metamorphosed into juveniles and settle down to some suitable grounds for further growth. Such are the

8) No Tropic Region is definable distinctly within the Japan Sea, although some patches of the water mass of different sizes which is reminiscent of the Tropic water are met with temporarily with in the southeast portion of the Superficial Water in summer. 
situations till the beginning of the meteorological winter season.

There are, on the other hand, ample evidences suggesting that the majority of the tropical and subtropical populations carried into this marginal sea are perished without completing their life history there. Some prominent examples are as follows.

The porcupinefish Diodon holacanthus (pp. 53-54 of Part I). It is a very remarkable phenomenon observed frequently in winter along the Japan Sea coasts of middle to west Honshu and northwest Kyushu that an enormous number of young porcupinefish are drifted ashore and eventually to be perished. These populations are supposed to have been originated in the coastal areas of Luzon, Formosa, the Yayeyama Islands and vicinities and the pelagic young have been carried in large numbers into the Japan Sea by the warm current (Nishimura 1960a, 1961b, 1965). Probably most of the populations carried into this marginal sea are perished in this way.

The puffer Boesemanichthys firmamentum. In winter 1964-1965, a large number of this subtropical fish were stranded on the entire coast of San'in District west of Wakasa Bay and on the northwestern coast of Kyushu, with the density, for instance, 2000 individuals per $100 \mathrm{~m}$ of coast line per day in northwest Kyushu (KoBAyashi \& Mind 1966). They were all young individuals, $17-20 \mathrm{~cm}$ in total length, possibly of the same year class. Supposedly the populations entered the Japan Sea in the preceding autumn at the peak of the warm current and then were drifted ashore by the strong northwest monsoon (КовауAshi \& Mind op. cit.). A similar phenomenon was also recorded from Wakasa Bay and its vicinity in winter 1954-1955 (MATSUBARA 1955).

The triggerfish Canthidermis rotundatus (Tanaka 1915; Tokuhisa 1915). In early winter 1915, an enormous number of this balistid fish were washed ashore on the coasts of northern Honshu from Noto Peninsula to Akita Prefecture so that the inhabitants of the districts could pick up the stranded fish up to 300 per person at a time. Similar phenomena of a smaller scale were recorded in some past years, too. This triggerfish is quite unique among the balistid fishes in that it spends an epipelagic life associated with the floating Sargassum (OKuno et al. 1967). It seems that the populations of this fish are transported from the southern waters by warm currents.

Tropical sea turtles (pp. 54-55 of Part I; also, Nishimura \& Yasuda 1967, Nishimura 1968c). Judging from the frequency of observations, the wanderings of tropical sea turtles, especially the leatherback Dermochelys coriacea and the hawksbill Eretmochelys imbricata, into the Japan Sea are considered by no means rare; but they are mostly found stranded on the coasts of Honshu Island after the stormy weather in winter, dead or nearly exhausted. They are evidently originated in the southern East China Sea or the South China Sea, and most of the populations having entered the Japan Sea are to be perished. It is known for the hawksbill turtle at least that the individuals which wander about such a long distance are without exception young animals. The loggerhead turtle Caretta caretta is not concerned here, since it is a warm- 
temperate neritic species (NISHIMURA 1967), and no prominent winter stranding is known about this animal.

Sea snakes, especially Pelamis (=Pelamydrus) platurus (p. 55 of Part I). Several species of sea snakes are caught in the Japan Sea; their occurrence pattern is just the same as that of the tropical sea turtles mentioned above. The commonest is Pelamis platurus, the species believed most well adapted to the pelagic life, and this is stranded not infrequently on the coast of San'in District of west Honshu in particular. Although their exact natal place is not known, it is beyond doubt that they are originally the inhabitants of the tropical waters from where they are dispersed and the populations seen in the Japan Sea are all to be perished by late winter.

Tropical and subtropical pelagic cephalopods (Nishimura 1966, 1968a, 1968b). Of these, Thysanoteuthis rhombus and Argonauta argo are best known of their occurrence pattern in the Japan Sea. Supposedly they are driven into this sea by the warm current, then mostly drifted to the coasts of the Japanese Islands in winter eventually to be perished.

Giant rhizostomaean medusa Stomolophus nomurai. As mentioned already (p. 63 of Part I), a great number of this subtropical medusa are carried into the Japan Sea from time to time. Its natal place is supposed generally to be around the southern and southwestern coasts of Korean Peninsula (Nishimura 1959a, 1961a). There are some evidences suggesting that most of the medusae brought into the Japan Sea are eventually perished, partly by sinking down into the deeper cold water and partly by being washed ashore by winter storms. In the later stages of the 1958 outbreak, a large amount of the medusae, mostly dead and partly-disintegrated, was frequently caught in trawl net off almost the entire west coasts of Honshu and Hokkaido; the amount was often so large that the fishermen felt difficulties in lifing net and frequently had to discard the net (Nishimura 1959a). The stranding of the medusae was also prominent; according to my own observations made at a small stretch of coast near Niigata, middle Honshu, the stranding was not $d$ almost every day while the northwest monsoon was prevailing from middle October 1958 to January 1959 and at the peak of stranding in early January in a scale of up to 100 medusae being counted on about $300 \mathrm{~m}$ long beach.

Although the examples cited above seem mostly to be concerned with more or less conspicuous happenings so that one might regard them as abnormal phenomena. Actually, however, the similar phenomena occur almost every winter though in a smaller scale. As seen in the above examples, the decisive cause of the mass destruction of those tropical and subtropical populations is the drift toward the inshore waters by the northwest monsoon, eventually followed by the stranding, although the influence of low temperature of the inshore water may be fatal, too, in some occasions. The low temperature seems, however, to be more $\epsilon$ ffective to the coastal and offshore demersal populations than to the pelagic populations. The destructive sharp drop of water temperature will be brought about either by the chilling in situ or by the 
rapid upwelling of cold deep water. A mass mortality ascribed to the water tem.perature drop by local chilling was recorded in winter 1963 in a wide range of western Japan including the west $r \in$ gion of San'in District (Kondô 1963). It was of a quite big scale, and the organisms killed by the cold included the tropical-subtropical littoral fishes such as Stephanolepis cirrhifer and Siganus fuscescens, followcd by Callyodon ovifrons, Kyphosus lembus, Lethrinus haematopterus, etc. No doubt, similar mass mortalities of warm-water littoral animals have occurred repeatedly in the past. As to the mass mortalities due to the rapid upwelling of cold deep water, ITo (1961) refers to several instances observed on the coast of middle Honshu involving such subtropical or warm-temperate neritic fishes as Trachurus japonicus and Pneumatophorus japonicus.

It seems also very likely that much more numerous smaller or inconspicuous animals else than the above-mentioned ones are destroyed by either the winter monsoon or the low water temperature. TABETA \& Tsukahara (1967) report that together with large numbers of the puffer Boesemanichthys firmamentum (sce above), very many smaller fishes and invertebrates were found stranded after stormy weather on the beach near Fukuoka, northwest Kyushu, in the winter of 1965; they were young gadoid fish Bregmaceros, leptocephalus larvae of Apodes, the anchovy Engraulis japonicus, larval flatfishes, the sand-lance Ammodytes personatus, the crabs Eriocheir japonicus, Myra fugax, Leucosia longifrons, the shrimps Metapenaeopsis spp., Chlorotocus sp., lophogastrid mysids, the amphipod Oxycephalus sp., loligid cephalopod larvae, the chaetognaths Sagitta spp., etc. There are similar observations in my own experience on the beach near Niigata, middle Honshu (Nishimura, unpublished data). In addition to the porcupinefish, rhizostomacan medusa, Thysanoteuthis and Argonauta mentioned above, the following animals were not infrequently found stranded after the northwest monsoon: the trumpetfish Fistularia petimba, the triggerfish Stephanolepis cirrhifer, young fishes of the family Apogonidae, portunid swimming crabs (very often), some cuttlefishes of the genus Sepia s. lato (very often; mostly cuttlebones only, but sometimes with mantle), fresh molluscan shells such as Neverita didyma, Scapharca subcrenata, Mytilus sp. aff. galloprovincialis, Merethrix lamarckii, Gomphina veneriformis, etc. The majority of these animals are tropical to warm-temperate species, and such destructive strandings occur almost $\epsilon$ very winter in different scales.

Although it is not ascertained by direct observations, many other southern elements in the Japan Sea are supposedly unable to survive the winter there. SuzukI (1966) mentions that some tropical fishes such as Pomacentrus coelestis, Abudefduf vaigiensis, Microcanthus strigatus and Prionurus microlepidotus arc frcquently or occasionally observed around Tsukumo Bay of Noto Peninsula, middle Honshu, in the period from August to October when the warm current is strongest, but all of them are young and no adults are included. He suspects that these young are to be killed by cold in the winter. The same is true about the rockfish Girella punctata in Mutsu Bay at the northern tip of Honshu (Okuno 1965). It is stated that only the young of this fish are found in 
the bay and they are seemingly brought there by a larval drift from the southern waters and all to be killed by winter cold within the bay. According to him, the winter water temperature $\left(5-6^{\circ} \mathrm{C}\right)$ in Mutsu Bay is close to the lethal limit of this rockfish. Further according to UENo (1966), the young of this fish are also caught from the surrounding waters of Hokkaido, e.g. near Hakodate on the southern coast and off the mouth of River Ishikari on the western coast, though no adults are recorded at any place in Hokkaido. This rockfish has a prominent pelagic larval phase, and its young is one of the commonest larval fishes collected by surface plankton tow in the waters off west Kyushu and south to middle Honshu (Uchida \& Dotsu 1958). In view of all these, OKuno's (op. cit.) supposition on the origin and fate of this fish in the northern Japan Sea is very admissible.

A similar process can be suggested as to the subtropical mesopelagic animals such as the lampridiform fishes Regalecus russellii and Trachipterus ishikawai, the ocean sunfishes Mola mola and Masturus lanceolatus (pp. 68-71 of Part I), which are carried into the Japan Sea by the core water of the warm current. It is to be noted that so many Trachipterus ishikawai have been caught in Ryotsu Bay of Sado Island (Fig. 11 of Part I); they are considered to have invaded the sea through the Tsushima Straits in the warm season, then be brought up to the shallower layers by winter convection, driven to the west coast of Honshu and its adjacent islands, ard eventually stranded or caught in set net (pp. 96-97 of this paper). Thus, the bulk of the individuals carried into this marginal sea are supposedly perished.

Such a disastrous migration is further presumable as to the abyssal and abyssopelagic populations that ever penetrate into the Japan Sea from the Pacific deep. As mentioned already (pp. 344-346 of Part IV), the macrourid fish Coelorhynchus multispinulosus and the lanternfishes Diaphus coeruleus and Notoscopelus elongatus caught off the western San'in District, respectively represented by a few individuals, are considered to have been transported there from the East China Sea during their larval or nocturnal epipelagic phase. The fishes, sinking down to the well-developed continental shelf off the western San'in District (Fig. 44), can live and grow, and occasionally even reproduce there, since the bottom water covering the shelf of this region is warm enough even in midwinter (Fig. 35b) to permit these subtropical species to do so. However, it is seemingly very difficult or quite impossible at all that these fishes or their progenies survive in the more northerly regions where the continental shelf is generally much narrower and thus the deep cold water comes very near the coast; the fishes having finished their epipelagic phase and descending to the deeper layers will inevitably meet this cold water mass which will check them for further living.

Summing up all these informations, it is concluded that the Japan Sea is acting as a dead end in the propagative migration from their natal places in the southern waters for the majority of the tropical and subtropical populations invading there, by perishing them either through the winter stranding caused by the northwest 
monsoon for the epi- and mesopelagic populations, through the winter low temperature for the demersal populations on the shelf and the neritic populations, or through the contact with the cold deep water of the basin for the abyssal and abyssopelagic populations. The propagative migrations made by those populations into the Japan Sea are thus abortive in most cases (Fig. 47).

As to the arctic and subarctic populations, on the other hand, their migrations

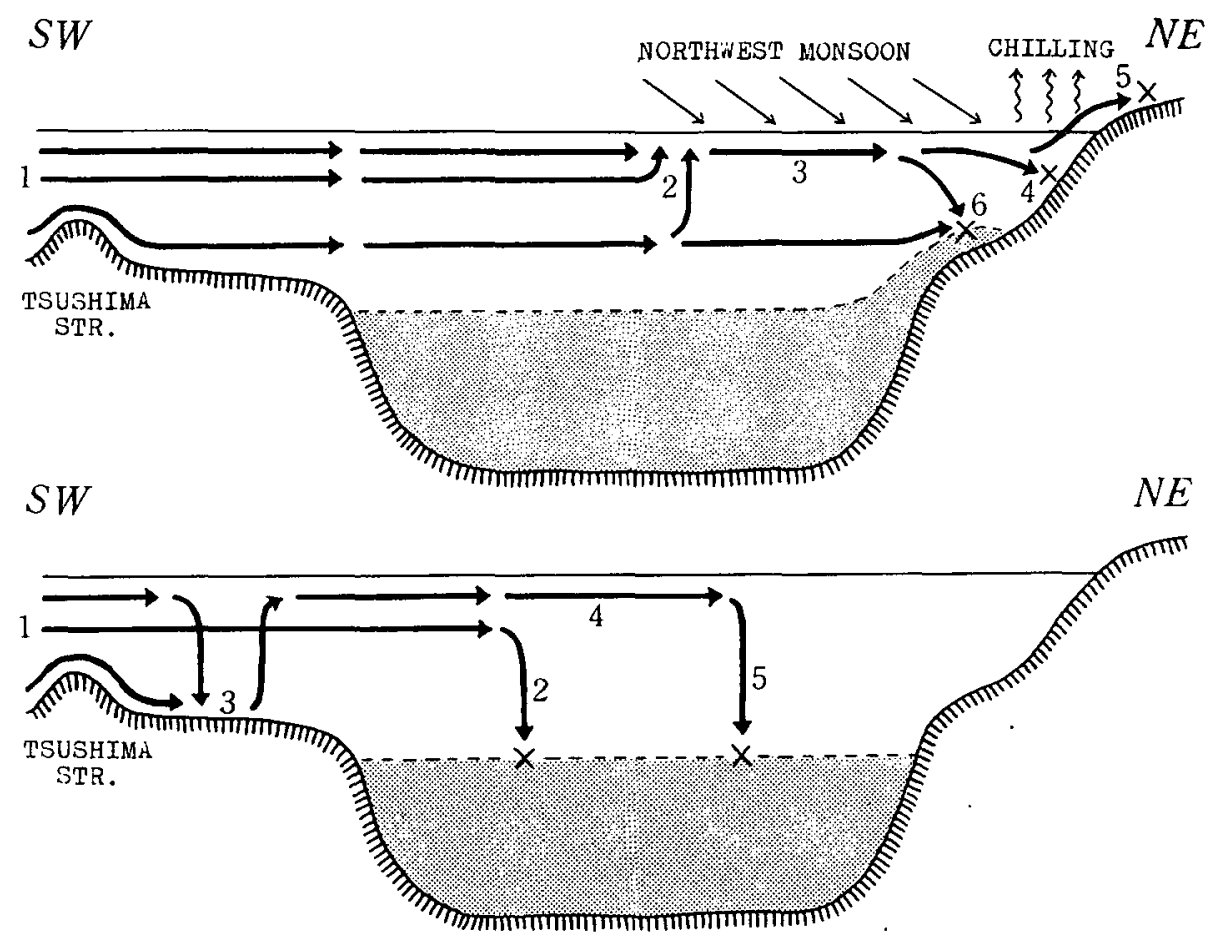

Fig. 47. Schematic illustrations of processes to the disastrous end of the tropical-subtropical populations invading the Japan Sea. Above for the epi-mesopelagic and neritic populations and the demersal populations on the shelf, and below for the abyssal and abyssopelagic populations.

Above: the populations that have entered the sea through the Tsushima Straits (1) are transported north by the warm current, but upon the beginning of the northwest monsoon, will be exposed to its influence. The mesopelagic populations are brought up to the surface by convection caused by the surface chilling (2) and, together with the epipelagic populations, are driven south toward the coasts of Japan (3). A part of such populations and those neritic or demersal on the shelf which have been carried into the coastal zone along the east coast of the sea will be enfeebled to death by rapidly lowering temperature of the coastal water (4), some by stranding on account of the monsoon gale (5), and some others by a contact with the upwelled deep water which is cold enouth to be fatal to them (6).

Below: the populations that have entered the Japan Sea through the Tsushima Straits in the larval or nocturnal pelagic phase (1) are transported far north by the warm current, descend to deeper levels upon the close of their pelagic phase and there will be killed by the low temperature of the deep water (2), although a small part will settle on the shelf floor off San'in District and survive (3). The offspring of such surviving population will bethen transported further north during their pelagic phase (4) and eventually be killed by the low temperature of the deep water occupying the major portion of the basin into which they may descend sooner or later (5). 
within the sea end very differently. Many northern populations, some holopelagic and others in larval pelagic stages, are driven south to the southeastern region of the Japan Sea by the prevailing drift current during the period from winter to early spring (Section 3.6 and pp. 81-82, 86, 90 of Part II). Approaching to the coast of the Japanese Islands or on the beginning of the temperature rise of the surface water in late spring, most of these populations descend to the deeper layers, $200 \mathrm{~m}$ or more, which are permanently occupied by the cold Lower Water masses (pp. $70 \& 73$ of this paper) and thus afford them a suitable environment for further living. Some of them may submerge at the Polar Front under the warm Upper Water mass, and eventually be brought back to the northerly region by the mid-depth return currents $\left(\mathbf{X}_{2}\right.$ and $\mathrm{X}_{3}$ in Fig. $37 a$ ). These are the processes of the migrations presumably followed by

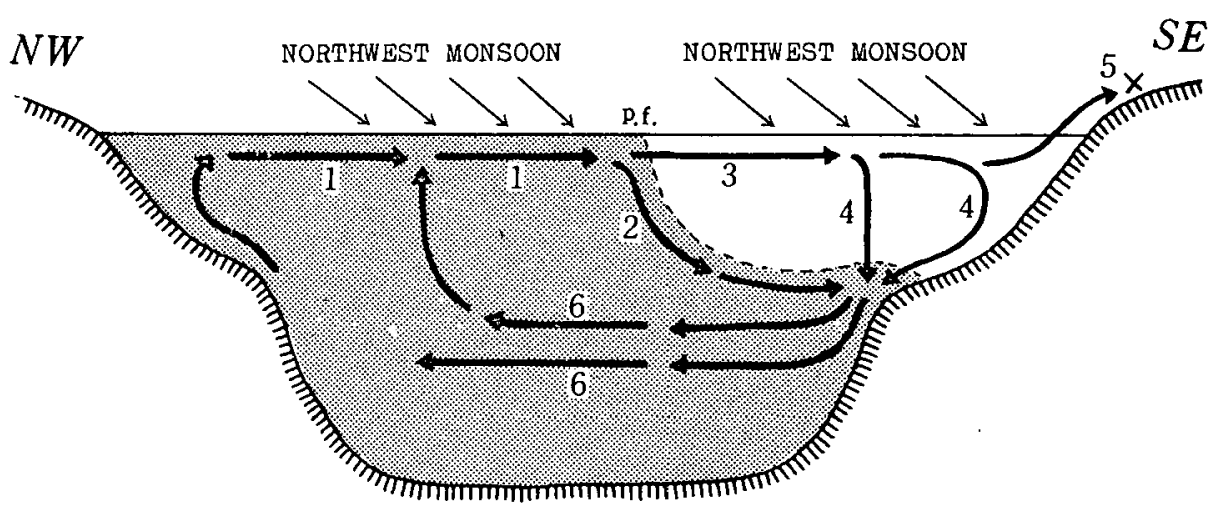

Fig. 48. Schematic illustration of the dispersal of the arctic-subarctic populations within the Japan Sea.

The populations coming up to the surface during their pelagic phase in winter are drifted south by the prevailing monsoon (1). A part of them descnd at the Polar Front (p.f.) below the upper warm water (2), while the rest are driven further south through the upper warm water (3) and then will descend to the cold deep water at the close of their pelagic phase or on the start of temperature rise in the coastal area (4), though a small part will be cast ashore by the monsoon (5). The populations having descended into the cold deep water may survive there or may eventually be brought back to their natal places in the northwestern region of the sea by the northerly return currents at lower levels $\left(6 ; \mathrm{X}_{2}\right.$ and $\mathrm{X}_{3}$ in Fig. $\left.37 a\right)$.

the cold-water bathy- or abyssopelagic animals during the period from winter to early summer (pp. 86-87 of this paper). Meanwhile, the bottom populations of the taraba community I off the west coast of middle Honshu are very probably recruited, partly at least, by the pelagic larvae from the northern waters in winter, which later settle down on the deep ground of the region to live there as adults (foot-note 5 on p. 338 of Part IV). The abundant occurrences of pelagic young of the Atka mackerel Pleurogrammus azonus in the surface layer off middle Honshu during the period from winter to early spring (pp. 74-77 of Part I) seem to show in a very clear-cut fashion the mechanism of recruitment suggested above as regards the origin of the populations of the taraba community I in that region. The supposed processes of the propagative 
migrations of the arctic-subarctic populations within the Japan Sea are schematically presented in Fig. 48, which is seemingly enough to show that the migrations are successful in most cases.

On the whole, it may be concluded that the Japan Sea is merely a temporal habitat to spend certain stages of the life history or a quite peripheral habitat for most of the tropical-subtropical populations, while it is a permanent habitat very favorable to most of the arctic-subarctic populations, especially to the eurybathyal or deep-water ones, throughout their life span.

\section{The Japan Sea as the Natural Environment of Animal Populations}

Next are given the most important distributional features and prominent faunistic characteristics of animal communities in the Japan Sea:

(1) Bioclimatic characteristics of respective animal communities of a wide variety are manifested very clearly. Tropical to arctic animal populations are distributed in the sea, some temporarily and others permanently, according to their bioclimatic characteristics. Generally speaking, the tropical-subtropical populations occupy the upper thin layer of the sea, while the arctic-subarctic populations occupy the lower incomparably big space; and the boundary between these two spaces is marked very distinctly.

(2) Seasonal succession is very marked. Distinct seasonal peculiarities are presented in the distribution pattern of respective animal communities. In summer, tropical-subtropical populations invade the sea and spread northward in the upper layer over an extensive area, especially some of the tropical surface populations including many neritic elements thrive remarkably even in the northernmost region of the sea. In winter, arctic-subarctic populations having risen to the surface layer are drifted south in large numbers to the southern coasts of the sea, together with or after the tropical-subtropical populations which are retreating from the north.

(3) As compared with the widely spread tropical surface populations mentioned above, the subtropical to warm-temperate mid-water populations are mostly confined to the southeastern half of the sea. The northern limit of their distribution is rather sharply defined.

(4) A larger part of the tropical-subtropical populations, especially both the tropical surface and neritic elements, are temporal inhabitants of the Japan Sea, while the arctic-subarctic pupulations are permanent inhabitants. The former having invaded the sea in summer are mostly perished in winter by stranding or the low water temparature, while the latter having drifted south in winter deep into the southeastern region of the sea descend to the lower cold layer and survive the following summer.

(5) In the northwestern region of the sea, the meteorological and biological seasons conform to each other. In the southeastern region, however, the biological 
seasons follow the meteorological seasons with a remarkable time lag due to the delay and prolongation of the biological summer and autumn, which in turn bring about there an unbalanced plankton production.

(6) The animal communities in the deep waters of the Japan Sea are markedly different from those in the Pacific deep. They are composed entirely of the arctic cold-water elements, but never of the 'ancient' tropical-subtropical type characterizing the Pacific deep water fauna. The animals of such 'ancient' warm-water type ever found sparsely in the Japan Sea are limited invariably to rather shallow layers and never in genuine deep waters.

The zoogeographical characteristics of the Japan Sea mentioned above are considered to be reflecting to a marked degree the following hydrographic characteristics of the sea:

(1) Great seasonal variations of hydrographic condition in the surface layer. The summer condition is largely tropical over the greater part of the sea, while in winter the condition becomes subtropical to warm-temperate in the southeastern region, subarctic in the intermediate region and truly arctic in the northwestern region. Such a state is comparable to the 'continental' state in meteorology.

(2) In the period from summer to autumn, the strong warm current with a great heat energy enters the sea through the southern straits, flows north through the southeastern half of the sea, and most of the volume eventually goes out after a month or more through the northeastern straits. The core water of the warm current is rather concentrated and strictly confined to the southeastern region of the sea by the distinct Polar Front formed along the northwestern margin of the water mass, though the surface water of the warm current, much more warmed and diluted than the core water, is driven and spread further north to northwest beyond the Polar Front.

(3) In the period from winter to spring, a strong southerly drift current is generated by the northwest monsoon over the entire region of the sea and the warm current retreats markedly. At the same time, through the development of thermohaline convection and freezing of large scales, the subtropical central water (=the Upper Water) is formed in the southeastern region, the subarctic intermediate water $(=$ the Southern Lower Water) in the intermediate region, and the purely arctic deep to bottom water ( $=$ the Northern Lower Water) in the northwestern region. Below the Upper Water mass, a very marked thermocline is formed and maintained throughout the year, separating the upper warmer layer from the lower cold layers permanently.

(4) The water masses formed by the winter physical processes in the Japan Sea considerably differ respectively from the water masses at the corresponding levels in the Pacific. Especially, the Upper Water and the Northern Lower Water are respectively distinctly colder and less haline than the Pacific central and deep to bottom water masses.

(5) The Northern Lower Water formed in the northwestern region of the sea in 
late winter will immediately sink down to lower levels eventually to join the bottom water maintained within the entire deep basin of the Japan Sea, without flowing out of the sea nor being mingled with the deep or bottom water of the adjoining seas.

In conclusion, the hydrographic characteristics mentioned above are to be ascribed to the geographical position and topography of the Japan Sea that is a deep marginal sea located in middle latitudes on the eastern border of a large continent and connected with the ocean through southern and northeastern straits each, however, completely obstructing the water exchange at deeper levels by a shallow sill. Unless under such a geographical situation, the Japan Sea would not be given any significant effects of the continental and monsoonal climate as well as of the intensified warm ocean current in the western North Pacific, neither can it sustain a unique independent deep environment, and hence any prominent zoogeographical aspects mentioned so-far in this series of papers would not be manifested.

\section{Summary}

The present series of papers is prepared to show the structural and dynamic aspects of the animal distribution in the Japan Sea from an ecological view-point on all kinds of data and information available. Particular attention has been paid to elucidate the relationships between the distributional patterns of animal populations and their environments and the mechanisms bringing about such characteristic distributional patterns of animals in this sea.

In Chapter 2 is made a short historical review of previous works on the zoogeography of the Japan Sea in a broad sense. Most of the previous works treated merely faunistic studies and only a few works were concerned with zoogeographical problems in the strict sense. Even those zoogeographical studies were imperfect, however, because the structural and dynamic aspects of the animal distribution were not discussed adequately in relation to the dynamic hydrological processes in the sea.

In Chapter 3, peculiarities in the distributional aspects of animal populations in the Japan Sea are described to make clear the most important points in the zoogeographical characteristics of the sea and to find out clues for the mechanisms bringing about such characteristics. The peculiarities discussed are:

1. Distribution patterns of northern and southern elements.

2. Occurrences of southern elements on the Japan Sea coasts of middle to west Honshu Island in winter.

3. Occurrences of neritic populations in the offshore region.

4. Scarcity of stenohaline epipelagic populations.

5. Frequent occurrences of some mesopelagic populations.

6. Southward dispersal of surface-living populations of the northern coastal origin in winter.

7. Seasonal cycles in production and distribution pattern of plankton. 
8. Migrations of the temperate and subtropical nektonic populations.

9. Vertical segregation of northern and southern elements.

10. Faunal zonation on the sea bottom; discrimination of "okaba" and "taraba" communities.

11. Horizontal and vertical ranges of respective bottom communities.

12. Characteristics of the deep water communities.

In Chapter 4, the zoogeographical peculiarities described in the preceding chapter are discussed in correlation with the hydrological and meteorological phenomena of the Japan Sea. A fine conformity has been revealed between the animal communities discriminated and the water masses defined in the sea. The conformity is so exact that the hydrological phenomena are inferable from the distribution and movement of the animal populations; this relationship was then appliad frequently to make clear certain hydrological phenomena and their implications.

Seasonal changes in the zoogeographical peculiarities are explained in relation with the hydrological and meteorological features of the Japan Sea. The most significant factors controlling the distribution of animal populations in this sea are the strong influx from summer to autumn of the warm Tsushima current consisting of tropical-subtropical, partly oceanic and partly strongly neritic water masses from the south on one hand, and the winter thermohaline convection and southward drift current induced by the cold and dry northwest monsoon on the other hand. From the view-point of the animal distribution, the circulation pattern of the surface water is supposed to differ markedly between summer-autumn and winter seasons. In spring, the warmer Upper Water mass seems to spread northward very rapidly. And in midsummer, the entire region of the Japan Sea is covered by a thin, warmed and much diluted layer of the Superficial Water, thus a remarkable propagation of neritic populations takes place even in the central offshore region of the sea. It is mentioned in detail how the movements and transformations of water masses affect the distribution pattern and its variations of animal populations in the Japan Sea.

In Chapter 5, the biological production and biological seasons in the Japan Sea are discussed. The plankton production is decidedly unbalanced in the southeastern region of the sea; this is because the biological summer and autumn both start in retard and are prolonged markedly there, and such a time lag is attributable to the effect of the warm Tsushima current. In the northwestern region, on the other hand, the biological seasons roughly conform to the meteorological seasons and the plankton production is balanced. The fate of the southern populations invading the Japan Sea and the processes of the propagative migration of northern populations within the sea are discussed. The Japan Sea is a dead end of their propagative migration for many tropical-subtropical populations that invaded the sea, while it is a permanent favorable habitat for most of the arctic-subarctic populations, especially the eurybathyal or deep-water animals.

In Chapter 6, it is concluded that the zoogeographical features of the Japan Sea 
discussed so far are reflecting in a high fidelity the prominent hydrological and climatological characteristics of the sea, which are then attributable to a marked degree to the geographical position and topography of this Far-Eastern marginal sea.

I heartily beg that what I have here done may be read with forbearance; and that my labours in a subject so difficult may be examined, not so much with the view to censure, as to remedy their defects-SIR $I$. $N$.

\section{REFERENCES*}

ABE, R. 1907. [Sea snakes in Province Izumo]. Zool. Mag., Tokyo, vol. 19, pp. 252-253 (J).

ABE, T. 1951. Notes : on the young of the "hokke" Pleurogrammus azonus Jordan et METz. Bull. Japan. Soc. Sci. Fish., vol. 16, pp. 495-501.

AIKAWA, H. 1936. On the diatom communities in the waters surrounding Japan. Rec. Oceanogr. Works Japan, vol. 8, pp. 1-159.

Akagawa, M. 1954. On the oceanographical conditions of the north Japan Sea (west off the TsugaruStraits) in summer (Part 1). J. Oceanogr. Soc. Japan, vol. 10, pp. 189-199. (J).

Andriashev, A.P. 1935. [New data on the deep-water fishes of the Bering Sea]. Dokl. AN. SSSR., tom 4, nos. 1-2, pp. 105-108. (R).

— 1953. Archaic deep-sea and secondary deep-sea fishes and their role in zoogeographical analysis. In Ocherki po Obshchim Voprosam Ikhtiologii, Izd. AN. SSSR., pp. 58-64. (R).

_ 1954. [Fishes of the Northern Seas of the U.S.S.R.] Izd. AN. SSSR., 566 pp. (R).

Androsova, E.I. 1958. Bryozoa of the order Cheilostomata of the north part of the Japan Sea. Issled. Dalnevost. Morei SSSR., vyp. 5, pp. 90-204. (R).

ANRAKU, M. 1953. Seasonal distribution of pelagic copepods at Oshoro Bay, west coast of Hokkaido. Bull. Fac. Fish., Hokkaido Univ., vol. 3, pp. 187-192.

Apanovich, S.I. 1962. [New objects in saury fisheries]. Rybn. Khoz., 1962, no. 1, pp. 9-13. (R).

Arakawa, H. 1942. [The Climate of the East Asia]. Asahishimbun-Sha, Tokyo, ix +199 pp., 1 map. (J).

- 1948. [The Climate of Japan]. Heibon-Sha, Tokyo, iv $+157+x x i+i v$ pp. (J).

ARakawa, K.Y. \& Masuda, S. 1961. Some observations on ocean sunfish, Mola mola (LinnÉ), with reference to its swimming behaviour and feeding habits. J. Japan. Ass. Zool. Gardens \& Aquariums, vol. 3, pp. 95-97. (J).

Anon. 1965. [Proceedings of the Fisheries Condition Forecasting Conference for the northern region of the Japan Sea]. Nihonkai-ku Suisan Shiken Kenkyâ Renraku Nyâsu, no. 171-172, p. 2. (J).

Balss, H. 1914. Ostasiatische Decapoden II. Die Natantia und Reptantia. Abh. Math.- Phys. Kl. K. Bayer. Akad. Wiss., II. Suppl.-Bd., 10. Abh. (Doflein, F.: Beiträge zur Naturgeschichte Ostasiens), pp. 1-101, pl. 1.

1924. Ditto V. Die Oxyrhynchen und Schlussteil. Arch. f. Naturgesch., 90. Jahrg., Abt. A, Nr. 5, pp. 20-84.

BekLemishev, C.V. 1954. [The feeding of some common plankton copepods in the Far Eastern seas]. Zool. Zh., tom 33, pp. 1210-1230. (R).

BeLchú, L.A. 1938. [On the problem of age determination of the Atka mackerel (Pleurogrammus azonus)]. Izv. TINRO., tom 14, pp. 165-168. (R).

Belyaev, G.M. 1966. Bottom Fauna of the Ultraabyssal Depths of the World Ocean. 〈Nauka〉, Moscow, 247 pp. (R).

* The next abbreviations are introduced: ( $J$ ), which means that the paper is written in Japanese; $(R)$, in Russian; etc. The brackets indicate that the title is translated into English by S. Nrshimura. 
Betesheva, E.I. 1954. [Distribution of larvae and young of fishes during winter in the Japan Sea]. Trudy Inst. Okeanol. AN. SSSR., tom 8, pp. 291-304. (R).

Bogorov, G.G. \& Vinogradov, M.E. 1955. Some essential features of zooplankton distribution in the North-Western Pacific. Ibid., tom 18, pp. 113-123. (R).

Bowman, T.E. 1960. The pelagic amphipod genus Parathemisto (Hyperiidea: Hyperiidae) in the North Pacific and adjacent Arctic Ocean. Proc. U.S. Nat. Mus., vol. 112, pp. 343-392.

Brodsky, K.A. 1937. Plankton investigations in the north-western part of the Japan Sea. Izv. TINRO., tom 12, pp. 159-182. (R).

1941. [On the plankton of the deep layers of the Japan Sea]. Issled. Dalnevost. Morei SSSR., vyp. 1, pp. 256-263. (R).

1948. [Free-living Copepoda of the Japan Sea]. Izv. TINRO., tom 26, pp. 3-130. (R).

1950. [Copepoda Calanoida of the Far Eastern Seas of the U.S.S.R. and the Polar Basin]. Izd. AN. SSSR., 1 col. pl., 442 pp. (R).

1955. Plankton of the North-Western Kuroshio and the Kurile region of the Pacific Ocean.

Trudy Inst. Okeanol. AN. SSSR., tom 18, pp. 124-133. (R).

- 1957. [Fauna of the Copepoda (Calanoida) and the Zoogeographical Division of the Northern

Part of the Pacific Ocean and Adjacent Waters]. Izd. AN. SSSR., 222 pp. (R).

1959. Zooplankton of sea waters of the South Sakhalin and South Kuril Islands. Issled.

Dalnevost. Morei SSSR., vyp. 6, pp. 5-46. (R).

1962. [A trial of biometrical analysis of morphological variability in Calanus pacificus BRoDSKY (Copepoda)]. Dokl. AN. SSSR., tom 142, pp. 1416-1419. (R).

BruUn, A.R. 1955. The ecological zonation of the deep-sea. UNESCO Symp. Phys. Oceanogr., 1955, Tokyo, pp. 160-168.

__ 1957. Deep sea and abyssal depths. In Hedgretr, J.W. (ed.): Treatise on Marine Ecology and Paleoecology, vol. 1 (Ecology), pp. 641-672.

Campbell, M.H. 1934. The life history and post-embryonic development of the copepods, Calanus tonsus Brady and Euchaeta japonica Marukawa. J. Biol. Bd. Canada, vol. 1, pp. 1-65.

Carlgren. O. 1921. Actiniaria. The Danish Ingolf Exped., vol. 5, pt. 9, 241 pp., 4 pls.

1940. Actiniaria from Alaska and Arctic waters. J. Washington Acad. Sci., vol. 30, pp. 21-27.

Chen, Q.-C. 1964. A study of the breeding periods, variation in sex ratio and in size of Calanus sinicus Brodsky. Oceanol. et Limnol. Sinica, vol. 6, pp. 272-288. (Chinese).

Clark, A.H. 1913. Cambrian holothurians. Amer. Naturalist, vol. 47, pp. 488-507.

\& CLARK, A.M. 1967. A monograph of the existing crinoids. Vol. I The comatulids, Part 5Suborders Oligophreata (concluded) and Macrophreata. Bull. U. S. Nat. Mus., 82, xiv +860 pp.

Cupp, E.E. 1937. Seasonal distribution and occurrence of marine diatoms and dinoflagellates at Scotch Cap, Alaska. Bull. Scripps Inst. Oceanogr., Techn. Ser., vol. 4, pp. 71-100.

1943. Marine plankton diatoms of the west coast of North America. Ibid., vol. 5, pp. 1-237.

Cushing, D.H. 1959. The seasonal variation in oceanic production as a problem in population dynamics. J. du Cons., vol. 24, pp. 455-464.

Derjugin, K.M. 1939. Zonen und Biocönosen der Bucht Peter des Grossen (das Japanische Meer). Sb. Posv. Nauchn. Dejat. N.M. KnIPOvitcha (1885-1931), VNIRO., pp. 115-142. (R).

— \& Somova, N.M. 1941. Contribution to quantitative estimate of the benthonic population of Peter the Great Bay (Japan Sea). Issled. Dalnevost. Morei SSSR., vyp 1, pp. 13-36. (R).

DJakonov, A.M. 1949. [Key to the echinoderms of the Far-Eastern seas]. Izv. TINRO., tom 30, pp. 4-127, pls. 1-22. (R).

- 1958. Echinodermata, excluded Holothurioidea, collected by the Kuril-Sakhalin Expedition in 1947-1949. Issled. Dalnevost. Morei SSSR., vyp. 5, pp. 271-357. (R).

Dor, K. 1958. [Exploration survey of new fishing grounds off the Oki Islands]. Tsushima Danrya Kaihatsu Chôsa Hôkokusho, Tokyo, part 3, pp. 19-24. (J).

Ekman, S. 1953. Zoogeography of the Sea. Sidgwick \& Jackson, London, xiv +417 pp. 
Elkina, B.N. 1962. On the Atkafish (Pleurogrammus azonus) of the south-castern region of the TatarStrait. Trudy Inst. Okeanol. AN. SSSR., tom 59, pp. 110-117. (R).

ENoмото, Y. 1957. Studies on plankton in the west coast of Kyushu I. On the seasonal successions of phytoplankton and zooplankton chiefly in 1954. Bull. Seikai Reg. Fish. Res. Lab., no. 11, pp. 1-9. 1959. Ditto II. On conditions for the vernal blooming of phytoplankton. Bull. Japan. Soc. Sci. Fish., vol. 25, pp. 172-182.

Filatova, Z.A. 1958. Bivalve molluscs of the abyssal zone of the North-Western Pacific. Proc. XV Int. Congr. Zool., London, Sect. III, pp. 221-222.

Fisher, W.K. 1911. Asteroidea of the North Pacific and adjacent waters Part 1. Phanerozonia and Spinulosa. Bull. U.S. Nat. Mus., 76, vi+419 pp., 122 pls.

Fisheries Agency of Japan 1954. Distribution and food habits of the fur seals of the North Pacific Ocean. Fish. Agen. Japan, Tokyo, 86 pp.

- 1958a. Tsushima Danryâ Kaihatsu Chôsa Hôkokusho I. Gyokyô Kaikyô Hen [Reports of the Exploitation Survey of the Tsushima Warm Current, Part I Fisheries Conditions and Hydrography]. Fish. Agen. Japan, Tokyo, xïi+ii +539 pp. $(\mathrm{J})$.

- 1958b. Ditto II. Gyoran Chigyo Purankuton Hen [Ditto, Part II Fish Eggs, Larvae and

Plankton]. Fish. Agen. Japan, Tokyo, ii +162 pp., 13 pls. (J). 1958c. Ditto III. Gyozyô Kaihatsu Hen [Ditto, Part III Exploitation of Fishing Grounds]. Fish. Agen. Japan, Tokyo, ii +264 pp., 3 pls. (J).

1958d. Ditto IV. Gyogyô Shigen Hen [Ditto, Part IV Fisheries Resources]. Fish. Agen. Japan, Tokyo, iii $+176+\mathrm{i}+84+\mathrm{i}+64$ pp. (J).

1962a. Nihonkai Hoppô Reisuieki Shin-gyozyô Kaihatsu Chôsa Gaihô I [Progress report of the exploitation survey for new fishing grounds in the northern cold-water region of the Japan Sea, Part I]. Japan Sea Reg. Fish. Res. Lab., Niigata, 34 pp, 8 pls. (J). 1962b. [Ditto, Part II]. Japan Sea Reg. Fish. Res. Lab., Niigata, 89 pp. (J).

Fukase, S. \& Furuhashi, K. 1952. Report on the plankton off the Sanin (Japan Sea) on Aug. 1950. J. Oceanogr., Maizuru Mar. Obs., vol. 1, no. 2, pp. 20-31. (J).

Fukataki, H. 1957. [Young Atka mackerel]. Nihonkai-ku Suisan Shiken Kenkyû Renraku Nyûsu, no. 77, p. $1 .(\mathrm{J})$.

1960a. [A few notes on the salmon shoals in the Japan Sea]. Nihonkai Kyokuzensen Gyozyô no Kenkyû, 1959, Japan Sea Reg. Fish. Res. Lab., Niigata, pp. 99-116. (J).

1960b. Consideration on the recruiting process of the jack-mackerel population in the Tsushima current region $\mathrm{I}$. Consideration from occurrence and distribution of larvae. Bull. Japan Sea Reg. Fish. Res. Lab., no. 6, pp. 69-85. (J).

\& Watanabe, K. 1960. Ditto II. Consideration from the body length composition of the young fish caught by the commercial fisheries. Ibid., no 6, pp. 87-103. (J).

— et al. 1961. [Fisheries biological studies on the salmons in the Japan Sea]. Nihonkai Kyokuzensen Gyozyô no Kenkyû, 1960, Japan Sea Reg. Fish. Res. Lab., Niigata, pp. 120-184. (J).

FukuokA, J. 1965. Hydrography of the adjacent sea (I). The circulation in the Japan Sea. J. Oceanogr. Soc. Japan, vol. 21, pp. 95-102.

Furuhasht, K. 1953. On the vertical distribution of animal plankton in the Sea of Japan off San'inDistrict in summer of 1952. Publ. Seto Mar. Biol. Lab., vol. 3, pp. 61-74.

1958. Notes on chaetognaths collected from the East China Sea. Umi to Sora, Kobe, vol. 34, pp. 31-34. (J).

- 1959. On the pelagic Chaetognatha collected from the Kuroshio warm current region south of Honshu Part I. Notes on some chaetognaths as indicator of "Kuroshio" area and cold water region. Ibid., vol. 35, pp. 81-84. (J).

1961. On the distributions of some plankton animals in the Kuroshio region south of Honshu, Japan, with notes on the nature and origin of the cold water mass appearing in the region $I$. The distributions of copepods and chaetognaths. Ibid., vol. 37, pp. 45-59. (J). 
et al. 1952. The report of the serial observation off the Kyoga-misaki made on board the R.M.S. "Kuroshio maru" in the winter seasons (No. 1). J. Oceanogr., Maizuru Mar. Obs., vol. 1, nos. 3-4, pp. 1-20. (J).

GaIL, G.I. 1936. Phytoplanktonuntersuchungen im nordwestlichen Teile des Japanischen Meeres. Vestn. Dalnevost. Fil. AN. SSSR., no. 18, pp. 81-108. (R).

1950. [Key to the phytoplankton of the Japan Sea]. Izv. TINRO., tom 33, pp. 3-177. (R).

Gilbert, C.H. \& HubBs, C.L. 1916. Report on the Japanese macrouroid fishes collected by the United States Fisheries steamer "Albatross" in 1906, with a synopsis of the genera. Proc. U.S. Nat. Mus., vol. 51, pp. 135-214, pls. 8-11.

GISLÉN, T. 1951. Crinoidea, with a summary of the bathymetric distribution of the deep-sea crinoids. Rep. Swedish Deep-Sea Exped., vol. 2, Zool., fasc. 1, pp. 49-59, pl. 4.

Gorbunova, N.N. 1958. [Observation on the spawing of the Atka fish]. Rybn. Khoz., 1958, no. 10, pp. 10-11. (R).

Grainger, E.H. 1961. Sea stars (Echinodermata: Asteroidea) of arctic North America. Bull. Fish. Res. Bd. Canada, no. 152, vii +70 pp.

Hachinohe Branch, Tohoku Regional Fisheries Research Laboratory 1952. Kaiyô Shigen Nempô, Shôwa 26 Nen-do, IV. Soko-uo Shigen Hen (Annual report on the fish resources in 1951, Section 4: Bottom fish). Hachinohe Br., Tohoku Reg. Fish. Res. Lab., Hachinohe. (J).

1954. Kaiyô Shigen Nempô, Shôwa 26-27 Nen-do, IV. Soko-uo Shigen Hen (Annual report on the fish resources in 1951-1952, Section 4: Bottom fish). Hachinohe Br., Tohoku Reg. Fish. Res. Lab., Hachinohe. (J).

Hamaee, M. \& Shimamura, H. 1954. Oki-tô Kinkai-san Gyorui Mokuroku [A list of fishes in the adjacent waters of the Oki Islands]. Japan Sea Reg. Fish. Res. Lab., Niigata, 6 pp. (J).

Harada, E. 1962. On the genus Scyllarus (Crustacea Decapoda: Reptantia) from Japan. Publ. Seto Mar. Biol. Lab., vol. 10, pp. 109-132, pls. 8-14.

1965. [Spiny lobsters of Province Kishu and their zoogeography]. Nanki Seibutsu, vol. 6, pp. 35-42. (J).

—_ \& Holthuis, L.B. 1965. Two species of the genus Ibacus (Crustacea Decapoda: Reptantia) from .Japan. Publ. Seto Mar. Biol. Lab., vol. 13, pp. 23-34, pl. 7.

HAYASHI, R. 1957. [Sea-stars of Sado Island]. Trans. Sado Nat. Hist. Soc., vol. 1, nos. 1-2, pp. $33-34$. $(\mathrm{J})$.

Hayashi, T. \& Yamaguchi, Y. 1960. Study on food niches of the benthic piscivores. Nôrin Suisan Gijutsu Kaigi Jimukyoku, Tokyo, 113 pp. (J).

Heatr, H. 1911. The Solenogastres. Mem. Mus. Comp. Zool. Harvard Coll., vol. 45, pp. 9-79.

Hedgpeth, J.W. 1957. Classification of marine environments. In Hedgpeth, J.W. (ed.): Treatise on Marine Ecology and Paeleoecology, vol. 1 (Ecology), pp. 17-28.

HeinRich, A.K. 1959. [Biological seasons in the plankton of the Bering Sea and horizontal distribution of the zooplankton biomass]. Trudy Inst. Okeanol. AN. SSSR,, tom 30, pp. 107-114. (R).

- 1961. Seasonal phenomena in plankton of the world ocean I. Seasonal phenomena in the plankton of high and temperate latitudes. Ibid., tom 51, pp. 57-81. (R).

1962. The life histories of plankton animals and seasonal cycles of plankton communities in the ocean. J. du Cons., vol. 27, pp. 15-24.

Hidaka, K. 1957. Influence of friction on geostrophic flow: sources of errors in dynamic computation of ocean currents. J. Oceanogr. Soc. Japan, vol. 13, pp. 37-49, 5 fold. tables.

Hikita, T. \& Mrsu, H. 1952. [Ichthyological survey in 1951]. Hokubu Nihonkai Shinkai Gyoden Chôsa Hôkoku, no. 3, pp. 5-70, pls. 1-15. (J).

Hirano, Y. 1947. On the Hokke (Pleurogrammus azonus Jordan et Metz) in Hokkaido. Hokusuishi Geppô, vol. 4, no. 1, pp. 10-22. (J).

— Kondô, H. 1948. On the development of atka mackerel eggs. Ibid., vol. 5, no. 3, pp. 1-3. (J). 
\& TAKahashi, T. 1943. [Some observations on the Hokke]. Hokusuishi Jigyô Jumpô, no. 577, pp. 162-164. (J).

Hokkaido Fisheries Experimental Station 1956. [Report of the experimental trawling in the Tartary Straits]. Hokkaido Fish. Exper. Sta., Yoichi. (J).

Hokkaido Fisheries Scientific Institution 1953. [Atka mackerel and its fisheries]. Hokkaido Fish. Sci. Inst., Yoichi. (J).

Hokkaido Hatchery Station 1959. [Report of the works in 1958]. Hokkaido Hatch. Sta., Sapporo. (J).

1960. [Report of the works in 1959]. Hokkaido Hatch. Sta., Sapporo. (J).

Hokkaido Regional Fisheries Research Laboratoy 1956. [Motor trawl fishery and its resources in Hokkaido]. Hokkaido Reg. Fish. Res. Lab., Yoichi, iii +142 pp. (J).

Honjo, K. et al. 1957. Distribution of Copepoda in the "Kuroshio" area, south of Honshu, May, 1955. Rec. Oceanogr. Works Japan, spec. no. 1, pp. 120-129.

Honma, Y. 1952. A list of the fishes collected in the Province of Echigo, including Sado Island. Japan. J. Ichthyol., vol. 2, pp. 138-145, 220-229. (J).

1954. On the rare bottom-fishes found in the vicinity of Province Echigo and Sado Island of the Japan Sea I. J. Fac. Sci., Niigata Univ., Ser. II, vol. 2, pp. 5-9.

1955a. Ditto II. Ibid., vol. 2, pp. 45-48.

1955b. A list of fishes found in the vicinity of Sado Marine Biological Station I. Ibid., vol. 2, pp. 49-60.

1955c. Further additions to "A list of the fishes collected in the Province of Echigo, including Sado Island" (I). Japan. J. Ichthyol., vol. 4, pp. 212-217. (J).

1955d. Ditto (II). Ibid., vo. 4, pp. 218-222. (J).

1955e. Ditto (III). Ibid., vo. 4, pp. 223-228. (J).

1956a. Ditto (IV). Ibid., vol. 5, pp. 59-60. (J).

1956b. A list of fishes found in the vicinity of Sado Marine Biological Station II. J. Fac. Sci., Niigata Univ., Ser. II, vol. 2, pp. 79-87.

1957a. On the rare bottom-fishes in the vicinity of Province Echigo and Sado Island of the Japan Sea III. Ibid., vol. 2, pp. 103-109.

- 1957b. A list of the fishes found in the vicinity of Sado Marine Biological Station III. Ibid., vol. 2, pp. 111-116.

1957c. Further additions to "A list of the fishes collected in the Province of Echigo, including Sado Island" (V). Japan. J. Ichthyol., vol. 6, pp. 109-112. (J).

1957d. Historical review on the fauna of Sado Island and adjacent waters. Trans. Sado Nat. Hist. Soc., vol. 1, nos. 1-2, pp. 81-93. (J).

1959a. Further additions to "A list of the fishes collected in the Province of Echigo, including Sado Island" (VI). Japan. J. Ichthyol., vol. 7, pp. 139-144. (J).

1959b. [Oncorhynchus gorbuscha on the west coast of Sado Island]. Nihonkai-ku Suisan Shiken Kenkyâ Renraku Nyûsu, no. 103, pp. 2-3. (J).

1962. Further additions to "A list of the fishes collected in the Province of Echigo, including Sado Island" (VII). Japan. J. Ichthyol., vol. 9, pp. 127-134. (J).

1963. Fish-fauna (Agnatha, Chondrichthyes, Osteichthyes) of Sado Island, Sea of Japan.

Publ. Sado Mus., no. 5, pp. 12-32. (J).

- \& KiтAm, T. 1967. A list of the fishes found in the vicinity of Sado Marine Biological Station

IV. Sci. Rep. Niigata Univ., Ser. D (Biol.), no. 4, pp. 59-74.

- \& Mrzusawa, R. 1966. Further additions to "A list of the fishes collected in the Province of Echigo, including Sado Island" (VIII). Japan. J. Ichthyol., vol. 14, pp. 53-61. (J).

- \& Sugthara, C. 1963. A revised list of the blennioid and ophidioid fishes of the suborder Blennina obtained from the waters of Sado Island, including the area of Yamagata Prefecture, Sea of Japan. Bull. Sado Mus., no. 11, pp. 5-9. (J). 
Horikoshi, M. 1962. Bird's eye view of the studies of the benthos in Japan. J. Oceanogr. Soc. Japan, 20th Anniv. Vol., pp. 707-723. (J).

HubBs, C.L. 1954. The distribution of macrourids. Union Inst. Sci. Biol., Sér. B, no. 16, pp. 62-64.

Huzino, T. 1952. Eretmochelys squamosa captured in Japan Sea. Collect. \& Breed., vol. 14, pp. 266267. (J).

IchikAWA, S. \& Yamad, M. 1957. [A List of Marine Invertebrates in the Vicinity of Oshoro Bay]. Sapporo, 13 pp. (J).

IızukA, A. 1949. On the distribution of Ceratium (Dinoflagellata) in the adjacent waters of Hokkaido. 1. The distribution of Ceratium in the offshore waters of western Hokkaido during the period from October to December, 1948. Sci. Pap. Hokkaido Fish. Sci. Inst., no. 3, pp. 1-8. (J).

1950. Ditto II. Seasonal and yearly fluctuation of Ceratium in Oshoro Bay and their oceanographic consideration. Ibid., no. 7, pp. 106-116. (J).

— \& TAMURA, M. 1953. [Patterns of spring plankton distribution in Ishikari Bay]. Hokusuishi Geppô, vol. 10, no. 6, pp. 39-50. (J).

-_, Yoshida, K. \& Kurohagi, S. 1951. [Peculiarities of plankton in Ishikari Bay in the spring to summer of 1950]. Ibid., vol. 8, no. 2, pp. 14-19. (J).

InouYe, K. 1955. [Noro-genge, Allolepis hollandi, as a potential resource from the deep sea]. Nihonkaiku Suisan Shiken Kenkyû Renraku Nyûsu, no. 55, p. 5. (J).

Isahaya, T. 1936. [On the bluefin tuna (Thunnus orientalis T. \& S.) in the coastal waters of Sakhalin]. Hokusuishi Jigyô Jumpô, no. 313, pp. 11-13. (J).

Ishryama, R. 1958. Studies on the rajid fishes (Rajidae) found in the waters around Japan. J. Shimonoseki Coll. Fish., vol. 7, pp. 193-394, 3 pls.

Iтo, K. 1967. A catalogue of the marine molluscan shell-fish collected on the coast of and off Tajima, Hyogo Prefecture. Bull. Japan Sea Reg. Fish. Res. Lab., no. 18, pp. 39-91. (J).

Iтo, S. 1961. Fishery biology of the sardine, Sardinops melanosticta (T. \& S.), in the waters around Japan. Ibid., no. 9, pp. i-vi, 1-227. (J).

- \& Yamaguchi, K. \& Iro, K. 1951. Investigation of migrating fish stock in the north of the Japan Sea, no. 1. Ibid., no. 1, pp. 1-36, i-iv. (J).

Ivanov, A.V. 1955. [Solenogastres]. In Uschakov, P.V. (ed.): Atlas Bespozvonochnykh Dalnevost. Morei SSSR., Izd. AN. SSSR., pp. 166-167, pl. 43. (R). 1963. Pogonophora. Academic Press, London; xvi $+479 \mathrm{pp}$.

IvLeVA, N.A. 1960. [Distribution character of zooplankton off the southwestern coast of Sakhalin]. Izv. TINRO., tom 46, pp. 65-77. (R).

IwasAwa, H. 1962. Marine invertebrates of Kanaizumi coast, Sado Island. Bull. Sado Mus., no. 9, pp. 7-13. (J).

Japan Sea Regional Fisheries Research Laboratory \& Ishikawa Prefectural Fisheries Experimental Station 1961. [Report of exploitation survey for the Alaska pollack grounds in the waters north of the Polar Front in the Japan Sea]. Japan Sea Reg. Fish. Res. Lab., Niigata. (J).

JoRDAN, D.S. 1901. The fish fauna of Japan, with observations on the geographical distribution of fishes. Science, 2nd ser., vol. 14, pp. 545-567.

1902. The fishes of Japan, with observations on the distribution of fishes. Pop. Sci. Month., vol. 60, pp. 76-79.

- \& Metz, C.M. 1913. A catalogue of the fishes known from the waters of Korea. Mem. Carnegie Mus., vol. 6, no. 2, pp. 1-65, pls. 1-10.

_ \& Thompson, W.F. 1914. Records of the fishes obtained in Japan in 1911. Ibid., vol. 6, no. 4, pp. 205-313, pls. 24-42.

Kambara, H. 1957a. Studies on "Hokke" Pleurogrammus azonus Jordan et Merz (I). Species and distribution. Hokusuishi Geppô, vol. 14, pp. 236-246. (J).

1957b. Ditto (II). Ecological study of spawning. Ibid., vol. 14, pp. 359-379. (J).

et al. 1953. Studies on the Hokke (Pleurogrammus azonus Jordan et METZ) I. The spawning season and the multiplicity of spawning. Bull. Hokkaido Reg. Fish. Res. Lab., no. 9, pp. 57-66. (J). 
Kamrta, T. 1941. Studies on the decapod crustaceans of Chosen, Part I. Crabs. Fisheries Society of Chosen, Keijô, 2 pls., pp. 1-289, 1 map."(J).

1958. Ditto, Part II. Hermit-crabs (5). Bull. Shimane Univ. (Nat. Sci.), no. 8, pp. 59-75. (J).

1962. Visits by unusual aquatic animals to the sea coasts of San-in District, Japan Sea. Sanin Bunka Kenkyû Kiyô, no. 2, pp. 1-35. (J).

Kamohara, T. 1949. Shinkai no Gyozoku [Fishes of the Deep Sea]. Nihon Shuppan Sha, Osaka, ii + iii $+189+$ viii pp. $(J)$.

Koronjr, K. 1957. Associations of plankton diatoms around Japan, as investigated by underway samplings aboard the "Oshoro Maru" in October and December 1952. Bull. Fac. Fish., Hokkaido Univ., vol. 7, pp. 271-283, 2 tables.

Kasahara, H. \& Ito, H. 1953. [Ecology of the mackerels]. Fish. Agen. Japan, Tokyo, 1 pl,, viii +131 pp. (J).

Kasahara, S. \& Ito, S. 1968. Studies on the migration of common squids in the Japan Sea II. Migrations and some biological aspects of common squids having occurred in the offshore regions of the Japan Sea during the autumn season of 1966 and 1967. Bull. Japan Sea Reg. Fish. Res. Lab., no. 20, pp. 49-69. (J).

Katayama, M. 1940. [A list of fishes of Toyama Bay]. Toyama Hakubutsu Gakkaishi, no. 3, pp. 1-28. (J).

1942. A new macrouroid fish from the Japan Sea. Zool. Mag., Tokyo, vol. 54, pp. 332-334.

Kato, A. \& Shimomura, T. 1959. Some characteristics on the D.S.L. peculiar to the Japan Sea. Bull. Japan Sea Reg. Fish. Res. Lab., no. 7, pp. 67-83. (J).

КАтон, G. 1956. A list of marine-fishes recorded in the Japan Sea (rev. ed.) Japan Sea Reg. Fish. Res. Lab., Niigata, 24 pp., 1 fold. table. (J).

Kawana, T. 1941. [A few data on the fisheries products in Province Echizen]. Suisan Kenkyû Shi, vol. 36, pp. 113-114. (J).

KAWASAKI, H. 1956. [On the maritime meteorology between Vladivostok and Tsuruga under the northwest monsoon]. Bull. Maizuru Mar. Obs., no. 5, pp. 1-6. (J).

Kawasaki, T. 1958. Biological comparison between the Pacific tunas, Part I. Bull. Tohoku Reg. Fish. Res. Lab., no. 12, pp. 46-79.

1960. Ditto, Part II. Ibid., no. 16, pp. 1-40. (J).

KIKUCH, K. 1931. [A catalogue of the fishes of Toyama Bay (Catalogues of the biological survey of Toyama Bay III)]. Toyama Kyôiku, no. 206, 34 pp. (J).

1935. [Two cases of collecting molluscs]. Hakubutsu Gakkai Shi, no. 4, pp. 1-5. (J).

1937. [An outline of the fauna of Toyama Bay]. Ibid., no. 5, pp. 8-11. (J).

1960-1963. Decapod crustaceans of Sado Island and adjacent waters I-IV. Bull. Sado Mus., no. 5 , pp. $1-4$, no. 8 , pp. $1-5$, no. 9 , pp. 1-6, no. 11 , pp. $1-4$. (J).

KIMURA, K. 1954. Analysis of skipjack (Katsuwonus pelamis) shoals in the waters of "Tohoku Kaiku" by its assaciation with other animals and objects based on the records by fishing boats. Bull. Tohoku Reg. Fish. Res. Lab., no. 3, pp. 1-87. (J).

KimURA, S. 1956. [The death register of whales-a peculiar whaling statistics]. Geiken Tsûshin, no. 63, pp. 144-150. (J).

Kinoshita, T. 1939. [Three strange animals on the beach near Yoichi]. Hokusuishi Jigyô Jumpô, no. 443, pp. 227-228. (J).

\& IMAI, H. 1936. [Chirocentrus dorab caught at Yoichi]. Ibid., no. 331, p. 12. (J).

KISHINovYE, K. 1922. [Echizen-kurage, Nemopilema nomurai n. gen., n. sp.]. Zool. Mag., Tokyo, vol. 14, pp. 343-346. (J).

- 1926. Two rare and remarkable forms of macrurous Crustacea from Japan. Annot. Zool. Japon., vol. 11, pp. 63-70.

Kitano, Y. \& Kanamaru, S. 1960. Hokkaido Chûgata Kisen Sokobiki-ami Gyogyô [Middle-class Motor Trawl Fishery of Hokkaido]. Hokkaido Kisen Gyogyô Kyôdô Kumiai Rengôkai, Sapporo. (J). 
Kryomatsu, T. 1956. [A hawksbill caught on the coast of Tottori Prefecture]. Collect. \& Breed., vol. 18, p. $377 .(\mathrm{J})$.

Kobayashi, Katsumi \& Midd, T. 1966. On the mass mortality of the puffer, Boesemanichthys firmamentum (Temminck et Schlegel) in the coast of the Tsushima current in winter, 1965. Bull. Fukuoka Pref. Fish. Exp. Sta., no. 11, pp. 1-15. (J).

KoBAYASHI, KiYu 1962. Ichthyofauna of Oshoro Bay and adjacent waters. Bull. Fac. Fish., Hokkaido Univ., vo. 12, pp. 253-264.

Kobjakova, Z.I. 1958. 'Decapoda of the South Kurile Islands. Issled. Dalnevost. Morei SSSR., vyp. 5, pp. 220-248. (R).

1959. [Order Decapoda]. In Lindberg, G.U. (ed.): A list of the fauna of the sea waters of the South Sakhalin and South Kuril Islands. Issled. Dalnevost. Morei SSSR., vyp. 6, pp. 173-256. (R).

Kojima, I. \& Nakano, K. 1960. [Shrimp Fisheries in Rumoi District, Part 2]. Hokkaido Fish. Exp. Sta., Yoichi, $\mathrm{i}+\mathrm{i}+77$ pp. (J).

Кокиво, S. 1950a. [On the plankton of Mutsu Bay]. Bull. Res. Fish. Resources Aomori Pref., vol. 1, pp. 99-122. (J).

1950b. The ecology of certain copepods in Japan Sea and Mutsu Bay. Bull. Japan. Soc. Sci. Fish., vol. 16, pp. 215-220. (J).

1952. Results of the observations on the plankton and oceanography of Mutsu Bay during 1950, references being made also to the period 1946-1950. Bull. Mar. Biol. Sta. Asamushi, vol. 5 , pp. $1-54$.

Komar, T. 1948. [Animals of Japan, I]. Tomi-Shoten, Kyoto, v+140 pp. (J).

Komaki, Y. \& Matsue, Y. 1958. [Taxonomy and ecology of Euphausiacea]. Tsushima Danryû Kaihatsu Chôsa Hôkokusho, Tokyo, Part 2, pp. 146-159. (J).

Kondakov, N.N. 1941. [Cephalopods of the Far-Eastern seas of the U.S.S.R.]. Issled. Dalnevost. Morei SSSR., vyp. 1, pp. 216-255. (R).

Kondô, M. 1963. Massive destruction of fishes due to abnormal condition of the sea water in western Japan in winter, 1963. Bull. Seikai Reg. Fish. Res. Lab., no. 29, pp. 97-107. (J).

Kuвo, I. 1960. [Crustacea Decapoda: Macrura]. In Encyclopaedia Zoologica Illustrated in Colours, IV, Hokuryû-Kan, Tokyo, pp. 98-113. (J).

_ 1961. [Fisheries Resources Science; Special Part]. Kôseisha-Kôseikaku, Tokyo, 2 pls., vii +396 pp. (J).

-_. [\& Nakazawa, K.] 1947. [Decapoda: Macrura]. In Illustrated Encyclopaedia of the Fauna of Japan, Hokurya-Kan, Tokyo (rev. ed.), pp. 753-797. (J).

Kun, M.S. 1949. [Feeding of the Pacific herring in the northern part of the Tartary Straits]. Izv. TINRO., tom 29, pp. 107-138. (R).

- 1954. [Characteristics in the feeding of 1 -year and adult mackerels]. Ibid., tom 42, pp. 95-108. (R).

Kuroda, N. 1949. Notes on Mola mola (Linnaeus) and Masturus lanceolatus (LiÉnard). Seibutu, Sapporo, vol. 4, pp. 206-208. (J).

KURODA, R. 1955. On the water temperature in the fishing grounds of the skipjack, Katsuwonus pelamis (Linnaeus), caught in the north-eastern sea area along the Pacific coast of Japan. Bull. Tohoku Reg. Fish. Res. Lab., no. 4, pp. 47-61. (J).

Kuroda, T. 1935. A list of Japanese species of Buccinum. Venus, Malacol. Soc. Japan, vol. 5, pp. 149-161. (J).

- 1936. A list of Buccinidae of northern Japan. Ibid., vo. 6, pp. 175-187. (J).

- \& KIKUCHI, K. 1933. Studies on the molluscan fauna of Toyama Bay (1). Ibid., vol. 4, pp. 1-14, pl. 1. (J).

Kurozawa, T. 1937. [Sperm whales in adjacent waters of Japan]. Suisan Kenkya Shi, vol. 32. pp. $36-45 .(\mathrm{J})$.

Kuzuu, S. 1903. [A Guide to the Fisheries in Korean Waters]. Kokuryû-Kai, Tokyo. (J). 
Leonov, A.K. 1948. [Water masses of the Japan Sea]. Meteorol. i Gidrol., tom 6, pp. 61-78. (R). LindBerg, G.U. 1925. On the geographical distribution of the anadromous form of the Oncorhynchus masou (Brevoort). Byull. Kraevedch. Naucho-issled. Inst. Dalnevost. Univ., Vladivostok, tom 1, pp. 1-2. (R).

1928. Southern elements in the fish fauna of Peter the Great Bay (Sea of Japan). Dokl. AN. SSSR., 1928, no. 25, pp. 529-534. (R).

1947. [A preliminary list of fishes of the Japan Sea]. Izv. TINRO., tom 25, pp. 125-206. (R). 1959. [Subphylum Vertebrata]. In Lindberg, G.U. (ed.): A list of the fauna of the sea waters of the South Sakhalin and South Kuril Islands. Issled. Dalnevost. Morei SSSR., vyp. 6, pp. 173-256. (R).

Machinaka, S. 1960. Tagging experiments with the Japan Sea mackerel for the period 1952-1959. Ann. Rep. Japan Sea Reg. Fish. Res. Lab., no. 6, pp. 105-126. (J).

MADSEN, F.J. 1961. On the zoogeography and origin of the abyssal fauna in view of the knowledge of the Procellanasteridae. Galathea Report, vol. 4, pp. 177-218.

Marshall, N.B. 1954. Aspects of Deep Sea Biology. Hutchinson, London, 380 pp., 5 pls.

Matsubara, K. 1934. [On Oncorhynchus masou fished off Kumamoto Prefecture]. Yôshoku Kaishi, vol. 4, pp. 114-117. (J).

1955. Fish Morphology and Hierarchy, 3 vols. Ishizaki-Shoten, Tokyo, 1605 pp., 135 pls. (J).

Matsuura, Y. 1935a. Studies on the fin-whale, Balaenoptera physalus (L.), in the adjacent waters of Japan, with special reference to its distribution, migration and habits. Zool. Mag., Tokyo, vol. 47, pp. 355-371. (J).

- 1935b. On the sperm whale found in the adjacent waters of Japan. Bull. Japan. Soc. Sci. Fish., vol. 4, pp. 101-112. (J).

- 1935c. The distribution and habits of humpback whales in the adjacent waters of Japan. Ibid., vol. 4, pp. 161-170. (J).

1935d. On the lesser rorqual found in the adjacent waters of Japan. Ibid., vol. 4, pp. 325-330. (J).

- 1935e. [The distribution and habits of sei whales in the adjacent waters of Japan]. Shokubutsu oyobi Dôbutsu, vol. 3, pp. 1973-1980. (J).

- 1936. Studies on the right whale, Balaena glacialis BonNaterre, in the adjacent waters of Japan. Ibid., vol. 4, pp. 696-702. (J).

_ـ 1943. [Sea Mammals]. Tennen-Sha, Tokyo, 8 pls., v +298 pp. (J).

Meshcheryakova, I.M. 1954. [Summer plankton of the Japan Sea]. Izv. TINRO., tom 42, pp. 288-293. (R).

- 1960. [Seasonal changes of the plankton in offshore waters of the Japan Sea]. Ibid., tom 46, pp. 95-144. (R).

Misu, H. et al. 1955. Feeding habits of bottom fishes. In The investigations of demersal fish resources in the East China and the Yellow Seas (2), Seikai Reg. Fish. Res. Lab., Nagasaki, pp. 96-106. (J).

Mitani, F. 1959. On shoals of the yellowtail, Seriola quinqueradiata T. \& S., migrating to the waters around Hokkaido. Bull. Japan. Soc. Sci. Fish., vol, 25, pp. 7-11. (J).

—_ 1960. Fishery biology of the yellowtail, Seriola quinqueradiata T.\& S., inhabiting the waters around Japan. Mem. Fac. Agr., Kinki Univ., no. 1, pp. 81-300, 4 pls. (J).

Mrto, S. 1961. Pelagic fish eggs from Japanese waters-I. Clupeina, Chanina, Stomiatina, Myctophida, Anguilida, Belonida and Syngnathida. Sci. Bull. Fac. Agr., Kyushu Univ., vol. 18, pp. 285-310, pls. 20-34. (J).

_ـ 1966. [Illustration of Japanese Marine Plankton, vol. 7: Fish Eggs and Larvae]. Sôyô-Sha, Tokyo, 74 pp. (J).

Mryaguchi, K. 1957. Pink salmon (Oncorhynchus gorbuscha WAlB.) of the Japan Sea. Hokusuishi Geppô, vol. 14, pp. 141-150. (J).

1959. On the singular phenomenon and population of pink salmon in the Japan Sea. Ibid., vol. 16, pp. 256-264. (J). 
Mryazaki, M. 1952. The heat budget of the Japan Sea. Bull. Hokkaido Reg. Fish. Res. Lab., no. 4, pp. 1-54. (J).

1953. On the water masses of the Japan Sea. Ibid., no. 7, pp. 1-65. (J).

\& ABE, S. 1960. On the water masses in the Tsushima Current area. J. Oceanogr. Soc. Japan, vol. 16, pp. 59-68. (J).

Moiseev, P.A. 1953. [Cod and dabs of the Far-Eastern seas]. Izv. TINRO., tom 40, pp. 1-288. (R).

Mokievsky, O.B. 1954. [Quantitative distribution of the deep-water bottom fauna in the Japan Sea]. Trudy Inst. Okeanol. AN. SSSR., tom 8, pp. 147-163. (R).

MorI, T. 1952. Check list of the fishes of Korea. Mem. Hyogo Univ. Agr., vol. 1, no. 3, Biol. Ser., no. 1, 228.pp.

1956. Fishes of San-in district including Oki Islands and its adjacent waters (Southern Japan Sea). Ibid., vol. 2, no. 3, pp. 1-62. (J).

Mortimer, C.H. 1951. The use of models in the study of water movements in lakes. Verh. Internat. Ver. Limnol., Bd. 11, pp. 254-260.

1952. Water movements in stratified lakes, deduced from observations in Windermere and model experiments. Gen. Ass. Intenat. Un. Geold. Phys., Bruxelles, C.R. Rapp. Ass. Internat. Hydrol. Sci., tome 3, pp. 335-349.

1954. Models of the flow-pattern in lakes. Weather, vol. 9, pp. 177-184.

Motoda, S. 1944. [The Sea and Plankton]. Kawade-Shobô, Tokyo, ii +viii +235 pp. (J).

_ \& ANRAKU, M. 1958. [Results of survey of plankton: quantitative distribution]. Tsushima Danryû Kaihatsu Chôsa Hôkokusho, Tokyo, part 2, pp. 121-124, 13 pls. (J).

Nagata, K. \& Nishimura, T. 1960. [Crabs of Akita]. Funakawa Fish. Coop. Ass., Funakawa. (J).

Nakagawa, I. \& Takahashi, T. 1934. [Three temperate fishes collected from the vicinity of Yoichi]. Hokusuishi Jigyô Jumpô, no. 260, p. 12. (J).

NAKAI, Z. 1942a. [Plankton resources]. Kaiyô no Kagaku, Tokyo, vol. 2, pp. 181-188. (J).

— 1942b. [Sardine of Korea; its fishing condition and hydrography]. Ibid., vol. 2, pp. 198204. (J).

- 1942c. The chemical composition, volume, weight and size of the important marine plankton. J. Oceanogr. Soc. Japan, vol. 1, pp. 45-55. (J).

- et al. 1955. Progress report of the Cooperative Iwashi Resources Investigations, April 1949December 1951. Tokai Reg. Fish. Res. Lab., Tokyo, 116 pp.

- et al. 1957. A preliminary report on the biological survey in the "Kuroshio" area, south of Honshu, June-July, 1955. Rec. Oceanogr. Works Japan, spec. no. 1, pp. 159-196.

Nakamura, K. 1947. [Snakes and Their Merits and Harms]. Tomi-Shoten, Kyoto, 193 pp. (J). 1957. [Reptilia]. In Encyclopaedia Zoologica Illustrated in Colours, I, Hokuryû-Kan, Tokyo, pp. 283-324. (J).

Nakazawa, K. 1947. [Shira-ebi, Pasiphaea sivado (Risso)]. In Illustrated Encyclopedia of the Fauna of Japan, Hokuryû-Kan, Tokyo (rev. ed.), p. 786. (J).

Nemoto, T. 1959. Food of baleen whales with reference to whale movements. Sci. Rep. Whales Res. Inst., no. 14, pp. 149-190. 1 pl.

Nıкоцsкy, A.M. 1916. Faune de la Russie. Reptilia II. Ophidia. Mus. Zool. l'Acad. Imp. Sci., Petrograd, 349 pp. (R).

NishidA, K. 1935. [Results of drift bottle release and recovery in the Japan Sea]. Umi to Sora, Kobe, vol. 15, pp. 212-216. (J).

1955. [A Review on the Oceanographic Conditions and Fisheries in the Japan Sea]. Nihonkai Kaiyô Kishô Kyôkai, Maizuru, 113 pp. (J).

Nishimura, Saburo 1957. What is the spawner of the so-called "macrurus egg" from the adjacent waters to Japan? Ann. Rep. Japan Sea Reg. Fish. Res. Lab., no. 3, pp. 1-11. (J).

1958a. Mass stranding of porcupine puffer along the coasts of the Tsushima current region of the Japan Archipelago I. Occurrence of the mass stranding by regions (1). J. Oceanogr. Soc. Japan, vol. 14, pp. 53-58. (J). 
1958b. Ditto II. Occurrence of the mass stranding by regions (2). Ibid., vol. 14, pp.

59-63. (J).

1958c. Ditto III. Some ecological notes on the mass stranding. Ibid., vol. 14, pp. 103107. (J).

1958d. Ditto IV. A hypothesis for the mechanism of the mass stranding. Ibid., vol. 14, pp. 109-116. (J).

1958e. Quelques remarques sur l'ingestion du salpe, Salpa fusiformis Cuvier, chez les maquereaux pêchés dans la Mer du Japan orientale. Ann. Rep. Japan Sea Keg. Fish. Kes. Lab., no. 4, pp. 105-112. (J).

- 1958f. A short note on the penetration into and the migration in the Japan Sea of some tropical and subtropical aquatic animals. Ibid., no. 4, pp. 113-119. (J).

1959a. An outbreak of the gigantic stomolophid medusa in the Japan Sea and its adjacent waters. Collect. \& Breed., vol. 21, pp. 194-196, 202. (J).

1959b. Foods and feeding habit of the Pacific mackerel in the coastal waters of Ivingata Prefecture, Japan Sea, in 1958. Ann. Kep. Japan Sea Keg. Fish. Kes. Lab., no. 5, pp. 77-8/. (J).

- 1959c. Observations on the spawning and the early life history of the pearlsides in the adjacent waters to Noto Peninsula in the Japan Sea. Ibid., no. 5, pp. 61-75. (J).

1959d. A contribution to the study on the feeding habit of the racihc mackerel auring its overwintering period. Japan. J. Ecol, vol. 9, pp. 16-20. (J).

- 1960a. Some aspects of the natural history of porcupine puffers migrating to the Japanese waters I. Spawning and migration. Ibid., vol. 10, pp. 6-11. (J).

1960b. Occurrence of the giant flying squid, Thysanoteuthis rhombus Troschel, around Sado Island and off the coasts of Niigata Prefecture in the Japan Sea, with a short note on its estumated migration routes in adjacent waters to Japan. Collect. \& breed., vol. 22, pp. 168-170. (J).

- 1960c. Visits by unusual aquatic animals to the sea coasts of Nigata Prefecture during the winter of 1959-1960. Ibid., vol. 22, pp. 213-216. (J).

1960d. Alaska pollacks devouring the pearlsides. Ibid., vol. 22, pp. 87-88. (J).

1961a. Additional notes on the outbreak of a gigantic stomolophid medusa in the Tsushima current region of the Japan Archipelago in 1958-1959. Ibid., vol. 23, pp. 194-197. (J).

1961b. Miscellaneous notes on the biology of the porcupine fish, Diodon Part 1. Ibid., vol. 23, pp. 300-303. (J).

- 1961c. Records of the drift of whales to the near-shore waters of Sado Island, Japan Sea, in the XVII, XVIII and early half of the XIX century (1). Ibid., vol. 23, pp. 371-373, 375. (J).

1962a. Recent increase in the occurrence of the dealfish in adjacent waters to Japan. Bull. Japan Sea Reg. Fish. Res. Lab., no. 10, pp. 51-58.

- 1962b. Records of the oar-fish in Japanese waters, with notes on some aspects of its distribution. Sci. Rep. Yokosuka City Mus., no. 7, pp. 11-22. (J).

- 1963. Observations on the dealfish, Trachipterus ishikawai JoRDAN \& SNYDER, with descriptions of its parasites. Publ. Seto Mar. Biol. Lab., vol. 11, pp. 75-100, pl. 2.

- 1964a. Records of occurrence of the leatherback turtle in adjacent waters to Japan. Physiol. \& Ecol., Kyoto, vol. 12, pp. 286-290. (J).

1964b. Considerations on the migration of the leatherback turtle, Dermochelys coriacea (L.), in the Japanese and adjacent waters. Publ. Seto Mar. Biol. Lab., vol. 12, pp. 177-189.

- 1964c. Origin of the Japan Sea as viewed from the evolution and distribution of marine fauna,

Parts I \& II. Earth Science, Tokyo, nó. 73, pp. 18-27, no. 75, pp. 29-46. (J).

- 1964d. Additional information on the biology of the dealfish, Trachipterus ishikawai Jordan

\& SNyder Bull. Japan Sea Reg. Fish. Res. Lab., no. 13, pp. 127-129.

1965. Miscellaneous notes on the biology of the porcupine fish, Diodon Part 2. Collect. \& Breed., vol. 27, pp. 92-95. (J).

1966a. [The fauna of the Japan Sea-Some problems bearing upon its geologic history].

In Kaseno, Y. (ed.): Geoscience Problems of the Japan Sea, Kanazawa, pp. 135-143. (J). 
1966b. Notes on the occurrence and biology of the oceanic squid, Thysanoteuthis rhombus

Troschel, in Japan. Publ. Seto Mar. Biol. Lab., vol. 14, pp. 327-349.

1967. The loggerhead turtles in Japan and neighboring waters (Testudinata: Cheloniidae). Ibid., vol. 15, pp. 19-35.

1968a. Glimpse of the biology of Argonauta argo Linnaeus (Cephalopoda: Octopodida) in the Japanese waters. Ibid., vol. 16, pp. 61-70.

1968b. A preliminary list of the pelagic Cephalopoda from the Japan Sea. Ibid., vol. 16, pp. 71-83.

1968c. [The sea turtles of Japan]. Nature Study, Osaka, vol. 14, pp. 65-70. (J).

- \& Mizusawa, R. 1962. Exotic marine animals caught off Niigata Prefecture, Japan Sea,

during the winter of 1960-61. Collect. \& Breed., vol. 24, no. 3, pp. 32-35. (J).

\& Nishiwaki, M. 1964. Records of the beaked whale Mesoplodon from the Japan Sea. Publ.

Seto Mar. Biol. Lab., vol. 12, pp. 323-334, pls. 21-24.

- \& Окасні, I. 1957. A short note on the feeding of the mackerel in the middle Japan Sea during

its over-wintering period. Japan. J. Ecol., vol. 7, pp. 103-107. (J).

- \& YAMAZAKI, N. 1961a. Records of occurrence of a scyllarid lobster, Ibacus ciliatus (voN Siebold), off Niigata Prefecture. Collect. \& Breed., vol. 23, pp. 281-282. (J).

- \& 1961b. The occurrence of youngs of a scorpaenid fish, Plerois lunulata Temm. \& Schl., and a maltheid fish, Halieutaea stellata (VAHL), off Niigata Prefecture. Ibid,, vol. 23, pp. 279-280, 282. (J).

— \& YASUDA, T. 1967. Records of the hawksbill turtle, Eretmochelys imbricata (LiNnÉ), in the Japan Sea. Publ. Seto Mar. Biol. Lab., vol. 15, pp. 297-302.

Nishimura, Shigeki 1939. [Shrimps and crabs in the adjacent waters of Hokkaido and northern Kuril Islands]. Suisan Kenkyû Shi, vol. 34, pp. 382-385. (J).

Nomura, S. \& Hatai, K. 1936. A note on the zoological provinces in the Japanese seas. Bull. Biogeogr. Soc. Japan, vol. 6, pp. 207-214, pl. 13.

Norman, J.R. 1931. A History of Fishes. Ernest Benn, London, xv +463 pp., 7 pls.

\& Fraser, F.C. 1937. Giant Fishes, Whales and Dolphins. Putnam, London, xiii +361 pp., 8 col. pls.

Novikov, Y.V. 1957a. [A case of catch of Xesurus scalprum in the Maritime waters]. Izv. TINRO., tom 44, pp. $245-246$. (R).

1957b. [Balloonfish in Amur Bay]. Ibid., tom 44, pp. 246-247. (R).

ODATE, S. 1957. Studies on the larval fish of the Japanese anchovy, Engraulis japonica (HoutTUYN), in the north-eastern sea area of Japan. Bull. Tohoku Reg. Fish. Res. Lab., no. 9, pp. 111-128. (J).

Ogata, T. 1956. [Resources and fisheries of the bottom fishes in the Japan Sea: Hokke, Pleurogrammus azonus Jordan \& Metz]. Bull. Japan Sea Reg. Fish. Res. Lab., no. 4, pp. 183-196. (J).

- 1960. [Report of the Trawl Fishery Surveys in the Waters off the Maritime Province]. Nihonkai Kita-ku Rokken Suisan Kyôgi-kai, Niigata, iv +88 pp. (J).

Ogawa, T. 1961. Study on the fishes of the family Myctophidae in the northeastern sea area along the Pacific coast of Japan, Part I. Species and distribution. Bull. Tohoku Reg. Fish. Res. Lab., no. 19, pp. 81-89. (J).

Ogawa, Y. \& Nazumi, T. 1959. On the young Atka fish obtained from the stomach of pink salmon. Bull. Japan. Soc. Sci. Fish., vol. 24, pp. 893-895. (J).

Ohshima, Y. 1950. Biological notes on the sand-eel, Ammodytes personalus Girard. Ibid., vol. 16, pp. 99-107. (J).

Orrsuru, T. 1955. [History and present status of the motor trawl fishery]. Fish. Agen. Japan, Tokyo, 129 pp., 1 append. table. (J).

OKachI, I. 1954. A study on the structure of bottom fish communities in the Straits of Sado. Ann. Rep. Japan Sea Reg. Fish. Res. Lab., no. 1, pp. 57-63. (J).

1958. Studies on the distribution and structure of the fish fauna in the Japan Sea by catch statistics I. Seasonal distribution and fishing condition of the fishes in the Tsushima warm current system. Ibid., no. 4, pp. 1-13. (J). 
1963. Ditto II. Supplement of seasonal distribution and fishing condition of the bluefin tuna. Ibid., no. 11, pp. 9-21. (J).

OKadA, Y. 1947. [Geographical distribution of animals in Japan and adjacent regions]. In Illustrated Encyclopedia of the Fauna of Japan, Hokuryû-Kan, Tokyo (rev. ed.), pp. 1878-1893. (J).

OkiYama, M. 1965. On the feeding habit of the common squid, Todarodes pacificus Steenstrup, in the offshore region of the Japan Sea. Bull. Japan Sea Reg. Fish. Res. Lab., no. 14, pp. $31-41$. (J).

1967. [Deep-water biotic resources in the Japan Sea]. Nihonkai-ku Suisan Shiken Kenkyû Renraku Nyûsu, no. 194, p. 3. (J).

Okuda, S. 1943. The fauna of Akkeshi Bay XIV. Solenogastre. Annot. Zool. Japon., vol. 22, pp. 11-14.

Okuno, R. 1964. On the reef fishes of Tanabe Bay compared with those on the coral reefs of the Marshall Islands reported by Hiatt and Strasburg (1960). Physiol. \& Ecol., Kyoto, vol. 12, pp. 272-285. (J).

1965. Foods and behaviors of the rocky reef fishes on the coast of Asamushi, Mutsu Bay. Japan. J. Ecol., vol. 15, pp. 183-188. (J).

_ \& Nonogam, Y. 1965. [Report of researches of the Tajima Marine Park. Rocky reef fishes; species composition, distribution and behavior]. Kobe (private circulation). (J).

—_ et al. 1967. Underwater observations of reef fishes with reference to their micro-habitats and behaviours 6. Four species of family Balistidae. J. Japan. Ass. Zool. Gardens \& Aquariums, vol. 9, pp. 31-34. (J).

Omura, H. 1959. Bryde's whale from the coast of Japan. Sci. Rep. Whales Res. Inst., no. 14, pp. 133,6 pls.

___ \& Nemoto, T. 1955. Sei whales in the adjacent waters of Japan III. Relation between movement and water temperature of the sea. Ibid., no. 10, pp. 79-87.

- \& Sakiura, H. 1956. Studies on the little piked whale from the coast of Japan. Ibid., no. 11, pp. 1-37.

—_ et al. 1957. On the stock of baleen whales in the North Pacific. In SuYEHIRo, Y. et al. (ed.): Suisangaku Shûsei [Collected Papers in Fisheries Science], Univ. Tokyo Press, Tokyo, pp. 507521. (J).

Oshma, M. 1934a. List of fishes contained in the Saito Hoon Kwai Museum. Saito Ho-on Kai Hakubutsukan Jihô, no. 24, pp. 1-5. (J).

1934b. Occurrence of Cryptopsaras couesii in the Japanese water. Rec. Oceanogr. Works Japan, vol. 6, pp. 108-109.

Ouchr, A. 1954. Breeding of some species of flat fish in the Japan Sea. Ann. Rep. Japan Sea Reg. Fish. Res. Lab., no. 1, pp. 17-25. (J).

—_ 1955. [Is there any possibility to utilize the deep-water fish, Noro-genge Allolepis hollandi?]. Nihonkai-ku Suisan Shiken Kenkyû Renraku Nyûsu, no. 55, pp. 2-3. (J).

- 1960. Studies on the animal distribution in the abstained areas for trawl-fishery of the northern Japan Sea II. Benthic animals. Ann. Rep. Japan Sea Reg. Fish. Res. Lab., no. 6, pp. 173182. $(\mathrm{J})$.

1963. The bottom fish-fauna on the Hyotan and Mukoze Banks in the northern Japan Sea.

Bull. Japan Sea Reg. Fish. Res. Lab., no. 11, pp. 129-132. (J).

- \& Ogata, T. 1960a. Studies on the animal distribution in the abstained areas for trawlfishery of the northern Japan Sea I. Young bottom fishes. Ann. Rep. Japan Sea Reg. Fish. Res. Lab., no. 6, pp. 157-171. (J).

\& 1960b. Ditto III. Fishes. Ibid., no. 6, pp. 183-189. (J).

\& 1962. [Report of fisheries biological studies of the abstained area for trawlfishery in the Sado Straits]. Japan Sea Reg. Fish. Res. Lab., Niigata, iii +78 pp., 1 fold. map. (J).

Parin, N.V. 1960. Distribution of flying fish (Exocoetidae) in the western and central Pacific. Trudy Inst. Okeanol. AN. SSSR., tom 41, pp. 153-162. (R). 
Ponomareva, L.A. 1954. [Winter zooplankton in the northern part of the Sea of Japan]. Ibid., tom 9, pp. 159-172. (R).

1955. [Feeding and distribution of euphausiids in the Sea of Japan]. Zool. Zh., tom 34, pp. 85-97. (R).

1959. Some data on the zooplankton of the western coast of the South Sakhalin Island. Issled. Dalnevost. Morei SSSR., vyp. 6, pp. 47-57. (R).

1962. Euphausiids of the North Pacific. Trudy Inst. Okeanol. AN. SSSR., tom 58, pp. 135156. (R).

1963. [Euphausiids of the North Pacific; Their Distribution and Mass Species]. Izd. AN. SSSR., Moscow, 142 pp. (R).

Radzikhovskaya, M.A. 1961. [Water masses of the Japan Sea]. In Stepanov, V.N. (ed.): Osnovnye Cherty Geologii i Gidrologii Japonskovo Morja, Izd. AN. SSSR., Moscow, pp. 108-131. (R).

RAss, T.S. 1953. [Deep-water fishes of the Far-Eastern seas]. Priroda, 1953, no. 2, pp. 107-110. (R). 1954. [Deep-water fishes of the Far-Eastern seas of the U.S.S.R.]. Zool. Zh., tom 33, pp. 1312-1324. (R).

Rumyantzev, A.I. 1947. [On the changes in the composition of warm-water fish fauna of the Maritime waters in the Japan Sea]. Ibid., tom 26, pp. 47-52. (R).

Ryôke, Y. \& Asanaka, M. 1958. [Exploration survey of new fishing grounds off the Oki Islands]. Tsushima Danryû Kaihatsu Chôsa Hôkokusho, Tokyo, part 3, pp. 10-19. (J).

SAKaI, T. 1940. Bio-geographic review on the distribution of crabs in Japanese waters. Rec. Oceanogr. Works Japan, vol. 11, pp. 27-63.

SASAKr, M. 1929. A monograph of the dibranchiate cephalopods of the Japanese and adjacent waters. J. Fac. Agr., Hokkaido Imp. Univ., vol. 20, suppl. number, 357 pp., 30 pls.

Scheffer, V.B. 1958. Seals, Sea Lions, and Walruses: a Review of the Pinnipedia. Stanford Univ. Press, $x+179$ pp, 32 pls.

Schmidt, P. 1904. Pisces Marium Orientalium Imperii Rossici. Izd. Russk. Geogr. Obshch., S.Peterburg, xi+466 pp. (R).

1926. Zoology. In Fersman, A. (ed.): The Pacific Russian Scientific Investigations, Leningrad, pp. 137-160.

1935. [The Okhotsk Sea and its fish fauna]. Vestn. AN. SSSR., 1935, no. 5, pp. 29-38. (R). 1950. [The Fishes of the Okhotsk Sea]. Trudy Tikhookeansk. Kom. AN. SSSR., 370 pp., 20 pls. (R).

Semina, G.T. \& Zhuze, A.P. 1959. [Diatoms in the biocoenosis and thanatocoenosis of the western part of the Bering Sea]. Trudy Inst. Okeanol. AN. SSSR., tom 30, pp. 52-67. (R).

SENTA, T. 1958. [Studies on plankton: results of underway sampling between Nagasaki and the Gotô Islands in relation to the hydrographic and fisheries conditions]. Tsushima Danryû Kaihatsu Chôsa Hôkokusho, Tokyo, part 2, pp. 128-129. (J).

Shimane Prefectural Fisheries Experimental Station 1963. [Report of the 1962 survey on the ecology of youngs of the coastal fishes]. Hamada, Shimane Pref. (J).

Shimomura, T. 1954a. Planktological study on the warm Tsushima current regions I. Plankton properties and their relation to oceanographic conditions of Noto Peninsula-Sado Island region in the autumn of 19.50. Ann. Rep. Japan Sea Reg. Fish. Res. Lab., no. 1, pp. 127-138.

1954b. Ditto II. Plankton properties and their relation to oceanographic conditions of the central Japan Sea in the summer of 1951. Ibid., no. 1, pp. 139-152.

1957a. Ditto III. Plankton properties and their relation to oceanographic conditions of Noto Peninsula-Nyudo Saki region during the seasons from spring to winter, 1952. Bull. Japan Sea Reg. Fish. Res. Lab., no. 6, pp. 1-22.

- _ 1957b. Ditto IV. Plankton properties and their relation to oceanographic conditions of the offshore regions of the Japan Sea in the summer of 1955. Ibid., no. 6, pp. 129-138.

-1957c. Geographical distributions of larval fishes, Decapoda, Arthropoda and various eggs in the Japan Sea (in August, 1955). Ibid., no. 6, pp. 139-153. 
1959. On the unprecedented flourishing of "Echizen-Kurage", Stomolophus nomurai (KISHINOUYE), in the Tsushima warm current regions in autumn, 1958. Ibid., no. 7, pp. 85-107. (J).

1960a. [Fishing ground in the Polar Frontal zone of the Japan Sea in spring 1959]. Nihonkai Kyokuzensen Gyojô no Kenkyû [Studies on the fishing ground in the Polar Frontal zone of the Japan Sea], Japan Sea Reg. Fish. Res. Lab., Niigata, 1959, pp. 17-58. (J).

- 1960b. [A preliminary report on the race and migration of the pink salmon in the Japan Sea]. Ibid., 1959, pp. 59-78. (J).

1961. [Fishing ground in the Polar Frontal zone of the Japan Sea in spring 1960]. Ibid., 1960, pp. 26-111. (J).

\& Fukataki, H. 1957. On the year round occurrence and ecology of eggs and larvae of the principal fishes in the Japan Sea I. Bull. Japan Sea Reg. Fish. Res. Lab., no. 6, pp. 155-290.

Sizova, Y.V. 1961. [Circulation of waters in the Japan Sea]. In Stepanov, V.N. (ed.): Osnovnye Cherty Geologii i Gidrologii Japonskovo Morja, Izd. AN. SSSR., Moscow, pp. 146-154. (R).

SLePtzov, M.M. 1955. On the biology of cephalopod molluscs of the Far-Eastern seas and the northwestern Pacific. Trudy Inst. Okeanol. AN. SSSR., tom 18, pp. 69-77. (R).

Smirnova, L.I. 1959. [Phytoplankton of the Okhotsk Sea and the adjacent region of Kuriles]. Ibid., tom 30, pp. 1-5l. (R).

Smith, J.L.B. 1961. The Sea Fishes of Southern Africa (4th ed.). Central News Agency, S. Africa, xvi +580 pp., 109 col. pls.

SudA, K. 1929. [On a hydrographic condition in the western part of the Japan Sea]. Umi to Sora, Kobe, vol. 9, pp. 143-151. (J).

- 1932. On the bottom water of the Japan Sea (prelimianry report). J. Oceanogr., Imp. Mar. Obs. Kobe, vol. 4, pp. 221-240, 5 pls. (J).

1938. Annual variation of the Tusima current. Japan. J. Limnol., vol. 8, pp. 205-216. (J).

- \& HidakA, K. 1932. The results of the oceanographical observations on board R.M.S.

"Synpu Maru" in the southern part of the Japan Sea in the summer of 1929, Part I. J. Oceanogr., Imp. Mar. Obs. Kobe, vol. 3, pp. 291-375, 90 pls. (J).

_ et al. 1930. The results of the oceanographical observations on board M.S. "Synpu Maru" in the southern part of the Japan Sea in the summer of 1928, Part I and Part II. Ibid., vol. 2, pp. $1-73,155-264,115$ pls. (J).

__ et al. 1932. The results of the oceanographical observations on board R.M.S. "Syunpu Maru" in the principal part of the Japan Sea in the summer of 1930 . Ibid., vol. 4, pp. 1-173, 132 pls. (J).

Sugihara, C. 1944. [Report on the marine and freshwater fishes of Yamagata Prefecture, Part I]. Sakata (private circulation), 38 pp. (J).

Suyeniro, Y. 1951. Text-book of Ichthyology. Iwanami-Shoten, Tokyo, iii +vi +332 pp., 2 pls. (J).

- et al. 1962. A brief note on the benthic animals on the fourth cruise of the Japanese Expedition of Deep Seas (J.E.D.S.-4). Oceanogr. Mag., Tokyo, vol. 13, pp. 149-153.

Suzuki, K. 1966. An ecological study of the littoral fishes in and around the Bay of Tsukumo-wan, Noto Peninsula. Ann. Rep. Noto Mar. Lab., vol. 6, pp. 17-24. (J).

Suzuki, S. 1963. Fauna of the coast and the adjacent sea of Shônai I. Invertebrata. Yamagata (private circulation), 43 pp. $(\mathrm{J})$.

Sverdrup, H.U. 1953. On conditions for the vernal blooming of phytoplankton. J. du Cons., vol. 18, pp. 287-295.

Svetovidov, A.N. 1952. [Fluctuation in catch of the South Sakhalin herring and its causes]. Zool. Zh., tom 31, pp. 831-842. (R).

TABATA, K. 1958. [Report of the investigation of fishing ground exploitation by means of the D.S.L.]. Tsushima Danryû Kaihatsu Chôsa Hôkokusho, Tokyo, part 3, pp. 259-262. (J).

Tabeta, O. \& Tsukahara, H. 1967. Ecological studies on the fishes stranded upon the beach along the coast of the Tsushima current I. Fishes and other animals recorded during the first half of 1965 in northern Kyushu. Bull. Japan. Soc. Sci. Fish., vol. 33, pp. 295-302. 
TAGo, K. 1922. [On the whales inhabiting the adjacent waters of Japan]. Zool. Mag., Tokyo, vol. 34, pp. 446-479. (J).

TAKahashi, K. 1951. [Long-term Weather Forecasting]. Iwanami-Shoten, Tokyo, iii + 158 pp. (J). Takano, H. 1954. Preliminary report on the marine diatoms from Hachijô Island, Japan. Bull. Japan. Soc. Sci. Fish., vol. 19, pp. 1189-1196.

1955. Plankton diatoms collected off Bôsô District in August, 1951. Ibid., vol. 21, pp. 55-61. 1957. Synonymy of pelagic diatoms. Information Bull. Plankt. Japan, no. 4, pp. 10-13. (J). 1959. Plankton diatoms in western Aleutian waters in the summer, 1953. Bull. Tokai Reg. Fish. Res. Lab., no. 23, pp. 1-11. (J).

TAKI, I. 1938. Report of the biological survey of Mutsu Bay 31. Studies on chitons of Mutsu Bay with general discussion on chitons of Japan. Sci. Rep. Tohoku Imp. Univ., 4th Ser., Biol., vol. 12, pp. 323-423, pls. 14-34.

TANAKA, K. 1947. Daily change of plankton fauna and flora in Oshoro Bay during fishing season of spring herring. Hokusuishi Geppô, vol. 4, no. 6, pp. 8-12. (J).

TANAKA, O. 1956. The pelagic copepods of the Izu region, middle Japan. Systematic account $I$. Families Calanidae and Eucalanidae. Publ. Seto Mar. Biol. Lab., vol. 5, pp. 251-272.

— 1957. [Pelagic Copepoda]. In Suyehiro, Y. et al. (ed.): Suisangaku Shûsei [Collected Papers in Fisheries Science], Univ. Tokyo Press, Tokyo, pp. 259-284. (J).

___ \& Irzuka, S. 1956. On a Japanese squid "Surume-ika" Ommastrephes sloani pacificus (STEENSTRUP) in the north-western waters of Kyusyu. Bull. Fac. Fish., Nagasaki Univ., no. 4, pp. 31-40. $(\mathrm{J})$.

\& KoGA, F. 1958. [Studies on plankton: list of pelagic Copepoda, with a supplementary note on other plankton animals in the waters around Nagasaki]. Tsushima Danryû Kaihatsu Chôsa Hôkokusho, Tokyo, part 2, pp. 132-137. (J).

TANAKA, S. 1912. [Niigata and Noto as viewed from ichthyological data]. Zool. Mag., Tokyo, vol. 24, pp. 537-538. (J).

1915. [Drift of Canthidermis rotundatus to the coast of the Japan Sea]. Ibid., vol. 27, pp. 159160. (J).

1921. [Japanese Ichthyology I]. Shôka-Bô, Tokyo, 482 pp. (J).

1926. [Edible Fishes]. Nankô-Sha, Tokyo, 310 pp. (J).

1929. Distribution of fihes in Japan (1), (2). Zool. Mag., Tokyo, vol. 41, pp. 278-293, 301-

311. (J).

1930. [Ichthyological data (5)]. Ibid., vol. 42, pp. 455-465. (J).

- 1931. On the distribution of fishes in Japanese waters. J. Fac. Sci., Imp. Univ. Tokyo, Sec.

4, Zool., vol. 3, pp. 1-90.

- 1933a. [Studies on Fishes]. Issei-Dô, Tokyo, 356 pp. (J).

1933b. [Fishes]. In TANaka, S. et al. (ed.): Yûyô Yûgai Kanshô Suisan Dôshokubutsu Zusetsu [Illustrated Encyclopedia of Aquatic Animals and Plants of Economic Importance]. Daiichi-Shoin, Tokyo, pp. 74-350. (J).

- 1934. [Strange Fishes and Rare Fishes]. Kôgakukai-Shuppambu, Tokyo, 8 pls., vii +210 pp. $(\mathrm{J})$.

1936. [Fishes of Japan]. Dainihon Tosho K.K., Tokyo, $334+\mathrm{x}$ pp. (J).

- 1939. [Fishes as viewed from their habits (I)]. Collect. \& Breed., vol. 1, pp. 13-17. (J). 1943. [Taste and Nutrition of Edible Fishes]. Jidai-Sha, Tokyo, 24 pls., xxiii $+341+\mathbf{x x x}$ pp. $(\mathrm{J})$.

TAnigutr, M. 1961. Phytosociological Study of Marine Algae in Japan. Inouye-Shoten, Tokyo, 112 pp. $(J)$.

Taranetz, A.Y. 1937. Handbook for identification of fishes of Soviet Far East and adjacent waters. Izv. TINRO., tom 11, pp. 1-200, 1 map. (R).

1938. On new records of southern elements in ichthyofauna of northwestern part of Japan Sea. Vestn. Dalnevost. Fil. AN. SSSR., no. 28(1), pp. 113-129. (R). 
Teramachi, A. 1933. [The buccinid snail fishery in Toyama Bay]. Venus, Malacol. Soc. Japan, vol. 3, pp. 358-365. (J).

TokjokA, T. 1951. Pelagic tunicates and chaetognaths collected during the cruises to the New Yamato Bank in the Sea of Japan. Publ. Seto Mar. Biol. Lab., vol. 2, pp. 1-25, 1 fold. table.

1957. Chaetognaths collected by the Sôyô-Maru in the years 1934 and 1937-1929. Ibid., vol. 6, pp. 137-146.

1959. Observations on the taxonomy and distribution of chaetognaths of the North Pacific. Ibid., vol. 7, pp. 349-456.

Tokuhisa, M. 1915. [Abundant specimens of Canthidermis rotundatus]. Suisan Kenkyâ Shi, vol. 10, p. $94 .(\mathrm{J})$

Tomilin, A.G. 1962. [The Cetacean Fauna of the Seas of the U.S.S.R.]. Izd. AN. SSSR., Moscow, 1 pl., 212 pp. (R).

Tomryama, I. 1952. On some rare fishes from Japan and the Ryukyus. Annot. Zool. Japon., vol. 25, pp. 298-303.

— \& ABE, T. 1958. [Vertebrata: Pisces]. In Encyclopaedia Zoologica Illustrated in Colours, Hokuryû-Kan, Tokyo, II, pp. 1-306. (J).

Tully, J.P. 1964. Oceanographic regions and processes in the seasonal zone of the North Pacific Ocean. Studies on Oceanography, Tokyo, pp. 68-84.

UchidA, K. 1929. [Various adaptations of larval fishes to the environment]. Zool. Mag., Tokyo, vol. 41, pp. 373-374. (J).

- 1930. [Fishes, Cyclostomes and Cephalochordates]. Iwanami-Shoten, Tokyo, $118 \mathrm{pp} ., 1 \mathrm{pl}$. (J).

1936. [Marine fish fauna of Korea]. Zool. Mag., Tokyo, vol. 47, pp. 132-134. (J).

\& Dorsu, Y. 1958. [Studies on fish eggs and larve: general account of the pelagic fish eggs and larvae in the Tsushima warm current region]. Tsushima Danryû Kaihatsu Chôsa Hôkokusho, Tokyo, part 2, pp. 3-67. (J).

__ et al. 1958. Studies on the Eggs, Larvae and Juvenile of Japanese Fishes, Series I. Kyushu Univ., Fukuoka, viii $+89+x$ pp., 86 pls. (J).

Uchida, S. 1929. [On the distributon of marine animals around Noto Peninsula]. Zool. Mag., Tokyo, vol. 42, pp. 428-430. (J).

UDA, M. 1934a. The results of simultaneous oceanographical investigations in the Japan Sea and its adjacent waters in May and June, 1932. J. Imp. Fish. Exp. Sta., no. 5, pp. 57-190. (J).

- 1934b. Hydrographical researches on the normal monthly conditions in the Japan Sea, the Yellow Sea, and the Okhotsk Sea. Ibid., no. 5, pp. 191-236. (J).

1936. Results of simultaneous oceanographic investigations in the Japan Sea and its adjacent waters during October and November, 1933. Ibid., no. 7, pp. 91-151. (J).

- 1938. Notes on the origin of deep water in the seas adjacent to Japan. Japan. J. Limnol., vol. 8, pp. 195-204. (J).

1950. On the fluctuation of oceanic current (second report). Drift current in Japan Sea, Yellow Sea and East China Sea. J. Oceanogr. Soc. Japan, vol. 5, pp. 55-69. (J).

1960. [Fisheries Oceanography]. Kôseisha-Kôseikaku, Tokyo, 2 pls., ii $+\mathrm{ix}+347$ pp. (J).

Uekr, T. 1936. [On some pelagic animals of Toyama Bay]. Zool. Mag., Tokyo, vol. 48, p. 227. (J). 1943. [On a few problems concerning the animal distribution in Province Etchû]. Ibid, vol. 55, p. $68 .(\mathrm{J})$.

1957. [On Kikuchi's line]. Trans. Sado Nat. Hist. Soc., vol. 1, nos. 1-2, pp. 9-10. (J).

Ueno, T. 1964a. [A strange octopod caught at Furubira and Yoichi]. Hokusuishi Geppô, vol. 21 , pp. $427-428$. (J).

1964b. [Regalecus russellii and Trachipterus ishikawai caught at Furubira]. Ibid., vol. 21, pp. 471-474. $(\mathrm{J})$.

1965. [Fishes in the adjacent waters of Hokkaido 10. Clupeina]. Ibid., vol. 22, pp. 491496. (J). 
1966. [Ditto 17. Percina]. Ibid., vol. 23, pp. 268-278. (J).

Urita, T. 1934. On the Japanese Pandalus hypsinotus Brandt and its subspecies. Zool. Mag., Tokyo, vol. 46, pp. 254-260. (J).

Uschakov, P.V. 1955. [Polychaetous Annelids of the Far-Eastern Seas of the U.S.S.R.]. Izd. AN. SSSR., Moscow \& Leningrad, 1 pl., 445 pp. (R).

Utıмомi, H. 1955. Studies on the Cirripedia of Japan II. Geographical distribution. Bull. Biogeogr. Soc. Japan, vols. 16-19, pp. 113-123. (J).

Vinogradov, L.G. 1946. [On the geographical distribution of the Kamchatkan crab]. Izv. TINRO., tom 22, pp. 195-232. (R).

1948. [On the geographical division of the Far-Eastern seas]. Ibid., tom 28, pp. 162-163. (R).

Vinogradov, M.E. 1960. On the plankton of deep water in the Sea of Japan. Zool. Zh., tom 39, pp. 500-508. (R).

— 1968. Vertical Distribution of the Oceanic Zooplankton. 〈Nauka〉, Moscow, 320 pp. (R).

Watanabe, T. 1956a. [Resources and fisheries of the bottom fishes in the Japan Sea: Nigisu, Argentina semifasciata Kishinouye]. Bull. Japan Sea Reg. Fish. Res. Lab., no. 4, pp. 159-182. (J).

1956b. [Ditto: Sôhachi, Cleisthenes herzensteini (Schmidt)]. Ibid., no. 4, pp. 249-269. (J).

1958. The population studies of the bottom fishes in the southwestern region of the Japan Sea

II. Cline distribution observed on the growth of the plaice, Cleisthenes her zensteini (SCHMIDT). Ann. Rep. Japan Sea Reg. Fish. Res. Lab., no. 4, pp. 181-188. (J).

_ et al. 1958. A study on the structure of bottom fish communities at trawling ground, off Port Tsuiyama in Hyogo Prefecture. Bull. Fish. Exp. Sta. Hyogo-Ken, no. 9, pp. 1-20. (J).

—_ et al. 1960. [Trawling Fishery and Its Resources in the Southwestern Part of the Japan Sea]. Japan Sea Reg. Fish. Res. Lab., Niigata, 1 pl., 1 map, iv +196 pp., 4 tables. (J).

YABE, H. 1950. Juvenile of the pointed-tailed ocean sunfish, Masturus lanceolatus. Bull. Japan. Soc. Sci. Fish., vol. 16, pp. 40-42. (J).

Yakovleva, A.M. 1955. [The chitons-Loricata]. In Uschakov, P.V. (ed.): Atlas Bespozvonochnykh Dalnevost. Morei SSSR., Izd. AN. SSSR., pp. 162-166, pl. 43. (R).

YAMADA, T. 1937. On the spawning of the squid, Watasenia scintillans, in the waters of the east coast of Tyôsen. Bull. Japan. Soc. Sci. Fish., vol. 6, pp. 75-78. (J).

1938. [Supplementary note on the identification of some copepods]. 'Suisan Gakkwai Ho, vol. 7, pp. 183-188. (J).

Yamagata Prefectural Fisheries Experimental Station 1962. [Report of the 1961 survey on the ecology of young fishes]. Kamo, Yamagata Pref. (J).

—_ 1963. [Report of the 1962 survey on the ecology of young fishes]. Kamo, Yamagata Pref. $(\mathrm{J})$.

YAMAGUChI, E. \& YAMADA, M. 1955. [Marine Invertebrates of Northern Japan]. Hokkai Kyôiku Hyôron Sha, Sapporo, iv +189 pp. (J).

Yamanaka, I. \& Ito, S. 1957. Progress report of the Cooperative Iwashi Resources Investigations 1954. Japan Sea Reg. Fish. Res. Lab., Niigata, iii + 177 pp. (J).

YAMAZI, I. 1953. Plankton investigation in inlet waters along the coast of Japan VII. The plankton collected during the cruises to the New Yamato Bank in the Japan Sea. Publ. Seto Mar. Biol. Lab., vol. 3, pp. 75-108.

1956. Ditto XIX. Regional characteristics and classification of inlet waters based on the plankton communities. Ibid., vol. 5, pp. 157-196, 8 pls.

Yanat, R. 1950. The fishes of the Sanin district. Zool. Mag., Tokyo, vol. 59, pp. 17-22. (J).

YASUdA, F. \& MATSUOKA, T. 1962. Some consideration of the distribution of the northern limit of some coastal tropical fishes. Collect. \& Breed., vol. 24, no. 8, pp. 36-37. (J).

Yasuda, T. 1967. Feeding habit of the Zuwaigani, Chionoecetes opilio elongatus, in Wakasa Bay I. Specific composition of the stomach contents. Bull. Japan. Soc. Sci. Fish., vol. 33, pp. 315-319. (J). 
Yokoya, T. 1933. On the distribution of decapod crustaceans inhabiting the continental shelf around Japan, chiefly based upon the materials collected by S.S. Soyo-Maru, during the years 1923-1930. J. Coll. Agr., Tokyo Imp. Univ., vol. 12, pp. 1-226.

Yoshida, Y. \& Iro, T. 1957. Fish fauna of the Japan Sea. J. Shimonoseki Coll. Fish., vol. 6, pp. 261270. $(\mathrm{J})$.

Yusa, T. 1957. Studies on "Hokke" Pleurogrammus azontes Jordan et Metz (III). Embryonic and larval development. Hokusuishi Geppô, vol. 14, pp. 407-422. (J).

Zenkevitch, L. 1963. Biology of the Seas of the U.S.S.R. G. Allen \& Unwin, London, 955 pp. \& Birstein, J.A. 1960. On the problem of the antiquity of the deep-sea fauna. Deep-Sea Res., vol. 7, pp. 10-23. 